\title{
المساقات المفتوحة واسعة النطاق عبر الإنترنت: نحو منصة عربية للتعليم العالي
}

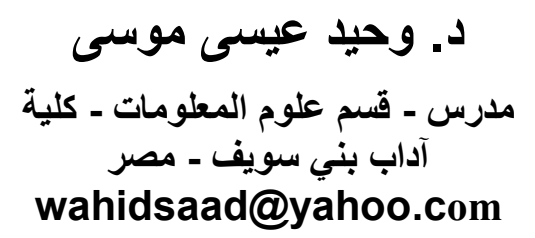

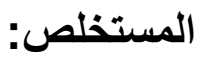

يعني البحث بدر اسـة المساقات المفتوحسة واسـعة

النطاق عبر الإنترنت، بهدف وضع تصور مقترح لمنصة موك عربية تعليمية متخصصة في مجال التعليم العالي.

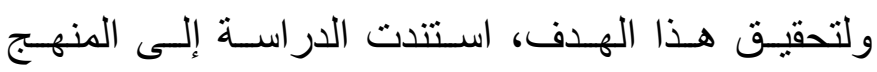
الوصفي التحليلي. 
بمشاركة عدد ضخم من المتعلمين، وخلق ميدان نقاش وتخاطب تعلمي بين المشاركين من متعلمين وهيئة تدريس، ويتم إتاحة هذه المساقات من خلال

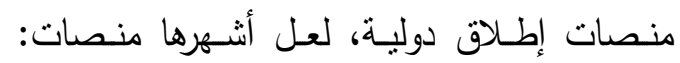
EDX, Udacity, Coursera, Khan Academy مـع عدد كبير مـن المؤسسات التعليميـة العريقة، وشركات البرمجيات الكبرى.

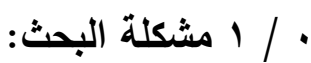

تتبع مشكلة البحث من عدم وجود منصة موك عربية تعليمية متخصصة في مجال التعليم العالي.

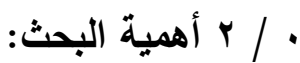
تبرز أهميـة البحث الحسالي مـن أهميـة موضوعه الذي يتتاوله، والذي تتبع أهميته من لهن الهن

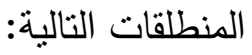

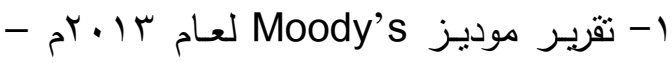

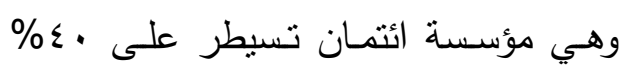

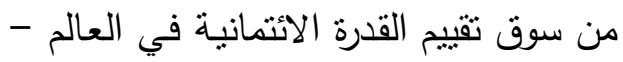
الذي أكد على أن المؤسسات التعليميـة سـتواجه نوعًا مـن الـضغط على جميـع مصادر الاخل نتيجة للتحولات الكلية للرؤى الاقتصادية والتكنولوجية والعامـة. وسيتطلب

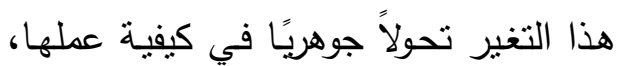
مهـا بتطلب الاتجـاه نحو خفض هياكل التكلفـة لتحقيـق الاسـتـامة الماليـة طويلــة الأجل، ويستوجب هذا تغييرًا جذريًا وآنيًا،

$$
\text { وعني البحث بتتاول مدخلين: }
$$

المسدخل الأول: نظري تـاول فيه ماهيـة

موك وتظوره، ومكوناته ومبادئه، ونماذجه، وكل

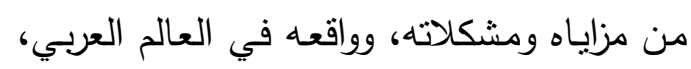
وجهود مؤسسات المعلومـات في موك، بتـاول مولي جهود OCLC

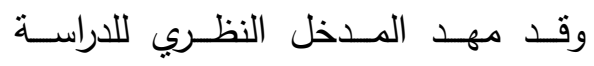
النطبيقية التي تتاولت: نمـاذج رائدة لمنصات

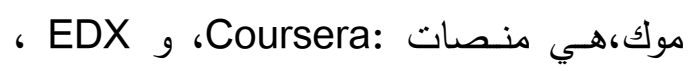
و Udacity وتطبيق معايير موك عليها، بهدف

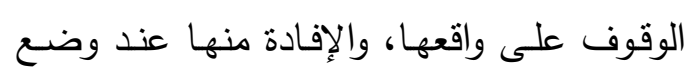
تصور لمنصة موك عربية. تعد المساقات المفتوحسة واسـعة النطـاق Massive Open (MOOCs) عبر الإنترنت Online Courses بعد Distance Learning والإعلام المجتمعي لني Social Media Open Educational التعليميــة المفتوحسـة وركة Resources (OER) التعلم الذي ترغبه، في الوقت الذي بناسبك، من

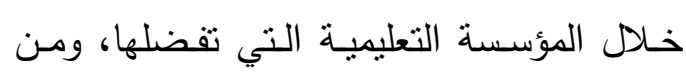
خلا الأستاذ الذي تأمله، وجميع ذلك بالمجان

والمسـساق المفتـوح واسـع النطـاق عبـر الإنترنت هو مساق تعليمي حديث ونانشئ، يستخدم الإنترنـت كأسلوب تعليمي مـن أساسياته السماح 
العدد الرابع والخمسـون - 7 •

الوزن التراكمي لتغيبر عـادات المستهلك، وتمكين تقنيات مثنل MOOCs والهواتف الذكيـة، وارتفـاع تكـاليف التعليم الجـامعي، لفياس سيعيد تثبيت التوقعات السابقة، وسيحدث واته تغيـيرات دائمسة في التعليم والتعلـم مـدى الحياة". (OCLC, 25 / 6 / 2014) ع- ما انتهى إليه تقرير قمـة جمعيـة المكتبات

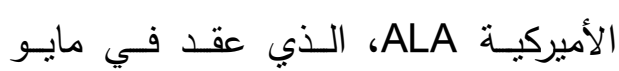
ـ ا • rم حول تتامي ظاهرة إنترنت الأشياء، من وجود علاقة وثيقة ينبغي أن تستثر

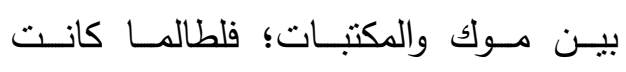
المكتبات هي جامعـة الشعب، وهي قادرة

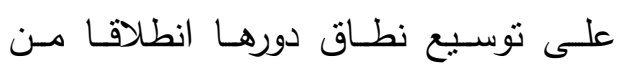
امتلاكهـا "للفـضـاء الافتراضــي، وإمكانيــة (ALA., 3 / 5 / / الوصول، والبنية التحتية"

0- النجاحات المذهلة التي حققها MOOCs؛ فقد وصل عدد المساقات المتاحة عبره لنحو

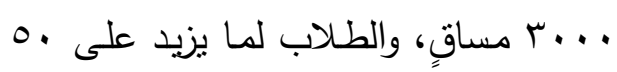

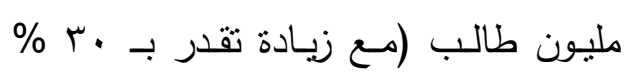

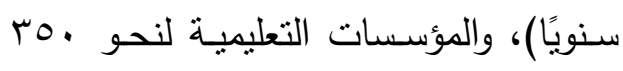
مؤسسة.

צ- الدعم الكبير الموجهـ له، المتمثل في وجود عدد مـن موفـري هـذه الخدمـة العمالقـة،

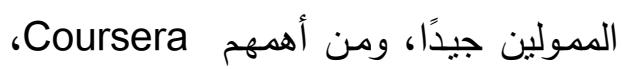

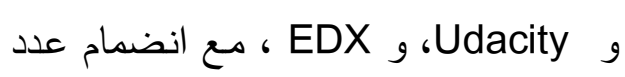
كبير من مؤسسات التعليم العالي المتطورة
من خـلال اعتمـاد تكنولوجيات تعلم هائلة

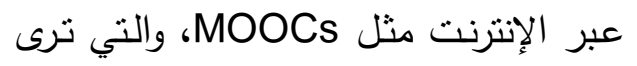
فيها موديز قدرة على تعطيل نماذج التعليم العالي التقليدية. (Chester, Timothy M) ,2013) IFLA ما أسفر عنه " ثقرير إفلا للاتجاهات Trend Report على:

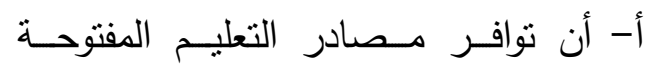

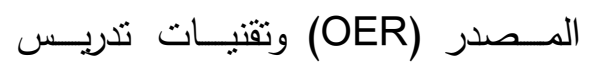
المساقات المفتوحة واسعة النطاق عبر الإنترنــ (MOOCs)، سـتعمل على إحداث تحولات في مشهد التعلم العالمي على مـــى العقـد المقبـل، وسـيكون للمكتبـات دور كبير في هذا الإطـار. (IFLA., 2014) ب- أن مساقات ودورات التعليم المفتوح على الإنترنت سوف تخدم مزيدًا من الدارسين والمهتمين الجدد في المستقبل القربب، والذي من المتوقع أن يفوق عددهم العدد الكلـــي للطــلاب الملتحقيــن حاليَّا بالجامعات في مختلف أنحاء العالم. ب- ما أسفر عنه تقرير فرق البحوث التسويقية في OCLC المعنون: "في نقطة التحول: التعليم والتعلم والمكتبـات"، الذي استتهدف تتبع تصورات المستهلكين للمعلومات لأكثر من عقد من الزمان، والذي أكد على: "أن 
خصخصته .

من هنـا تتبع أهميـة برامج MOOCs، ومن ثم تتبع أهمية البحث الحالي الذي يتتاوله، لهن لهن

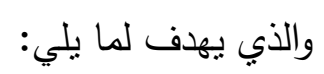

1- الدراسـة التحليلية لأشـهر المنصات الدولية، من خلال تطبيق معايير جودة التعلم عبر مـوك الـتي وضـــتها منظمـة الـشراكات الأكاديميـة ( Academic Partnerships AP العالم، لضمان كل من الجودة والدعم المالي ولي

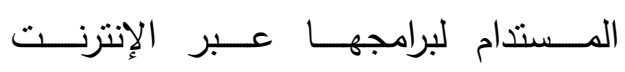
س الإنتر (Academic Partnerships) بهـدف الوقـوف على أفضل التطبيقـات وأنسبها للأخذ منها ما بناسب العالم العربي. r- وضـع تصور مقترح لمنصة موك عربيـة تعليميـة متخصسصة في مجـال التعليـم العالي.

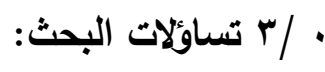
تسعى الدراسـة للإجابـة على التساؤلات

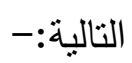
1- مـاذا يعني موك؟ ومـا مراحل تطوره؟ ومـا

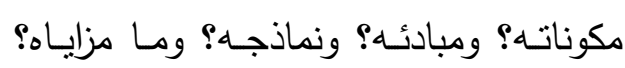
ومشكلاته؟

$$
\text { r- ما واقع موك في العالم العربي؟ }
$$

r- ما جهود مؤسسات المعلومات في موك؟ موك هل توجد مساقات صدرت لموك في مجال

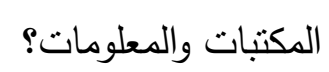

- خاصـة في أمريكا الشمالية - لـ مـوك، والتي كان من أثـهرها جامعات: هارفارد،

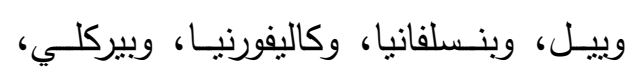

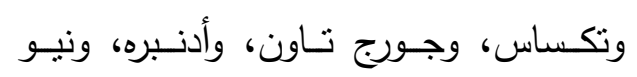

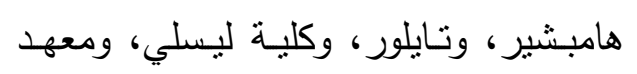

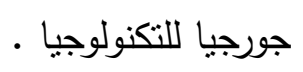

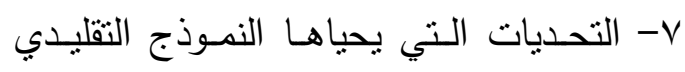
للتعليـم، ويـصبح لـبرامج MOOCs دور بارز في مواجنها، وتتمثل هذه التحديات فيما يلي: بارزي أ. تحديات على مستوى مصادر التعليم؛ إذ

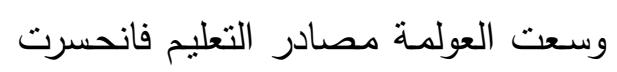
المـصادر المحليـة، وبـرزت المـصـادر الدولية المعتمدة على التعلم عبر الإنترنت، التي ترى البونسكو أنها تخفض تكاليف التعليم إلى التلث، وهناك برامج التعليم بـلا

$$
\text { حدود والتعليم المستمر • }
$$

ب. تحديات على مستوى تمويل التعليم؛ ومن جن ولن

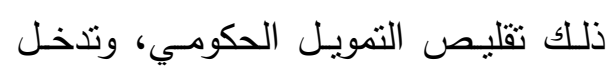
مؤسسات التمويل الدولية كالبنك الدولي، واليونسكو، وصندوق النقد الدولي، والتي

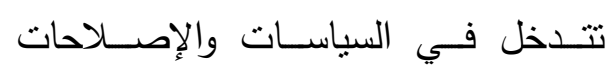
التعليمية التي ينبغي الأخذ بها وتطبيقها. ج. تحـديات على مستوى نوعيـة التعليم

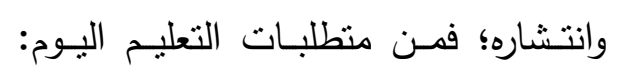
تكافؤ الفرص التعليمية (تحقيق المساواة)،

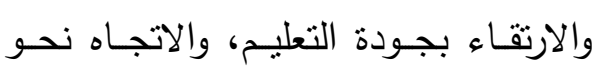


العدد الرابع والخمسـون - 7 •

$$
\text { ثمانى عبارات. }
$$

r- أهداف التعلم و الكفاءات، وتكون

$$
\text { هذا البند من خمس عبارات. }
$$

r- التقييم والقياس، وتكون هذا البند من

$$
\text { خمس عبارات. }
$$

ع- المحتوى التعليمي، وتكون هذا البند

$$
\text { من ثلاث عبارات. }
$$

ه- تفاعل المتعلمين ومشاركتهم، وتكون

$$
\text { هذا البند من أربع عبارات. }
$$

7- التكنولوجيات المستخدمة، وتكون هذا

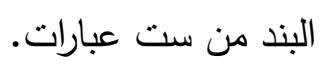

V- دعم المتعلم، وتكون هذا البند من سبارل

$$
\text { أربع عبارات. }
$$

1- إمكانيـة الوصسول، وتكون هذا البند

$$
\text { من خمس عبارات. }
$$

صدق الاستبيان وثباته:

أولاً: صدق الاستبيان:

للتأكد من صدق الاستبيان، قام الباحث

بعرضـه على عدد مـن المحكمين، ممن لهم اهتمام مباشـر بـ موك (ملحق رقم ع)، لإبداء رأيهم حوله، من ناحية ملائمة العبارات لأغراض الدراسـة، ومن حيث الصياغة والمضدون، وقد تم إعـادة صـياغة الاسـتبيان،حتى بـات في صورته النهائية. ثانياً: ثبات الاستبيان: - الانه

تم اختبار الاستنيان، وحساب معامل الثبات

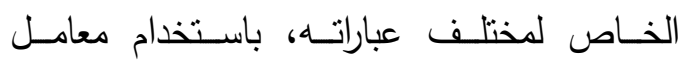

ع- مـا أفضل منصـات مـوك على المستوى

الدولي؟ مـا واقع التزامها بتطبيق معايير

موك؟ وكيف يمكن الإفادة منها في العالم

$$
\text { العربي؟ }
$$

ه- مـا التصور المقترح لمنصة مـوك عربيـة

موجهة للتعليم العالي؟ وما مراحلها؟ • / ع منهج البحث، وأدواته:

اعتمد الباحث المنهج الوصفي التحليلي

للوصول للأهداف المرجوة اعتمادًا على أداتي:

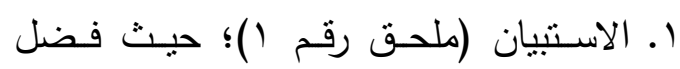

الباحث - للموضـوعية العلميـة - أن يتم

تطبيق معايير موك التي وضـتنها منظمـة

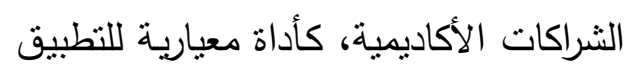
على المنصات الدوليـة قيد البحث، مـن وجهة نظر منتسبي المنصات أنفسهم من لن متعلمين وطلاب، فهم من خاض التجربـة كاملة، ومن ثم فهم أكفأ من يمكنه إبراز واقع المنظمات.

وتم استخدام مقياس (ليكرت) المتدرج من (1-1) ؛ حيث يشير الرقم (1) هنـا إلى أقل

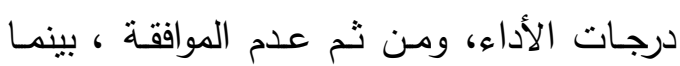
يشير الرقم (r) إلى أعلى درجات الأداء، ومن لهن ثم الموافقة. وضعت معابير موك في استبيان، شمل أربعين عبارة، استهدفت قياس البنود التالية: 1- المعـايير الخاصــة بمقدمـة المساق

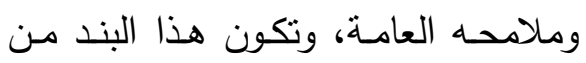


الخروج بها. ويتضح هــا مسن خـلال الجـدول

رقم(1):

كرونباخ ألفا Cronbach's Alpha، اعتمادًا على

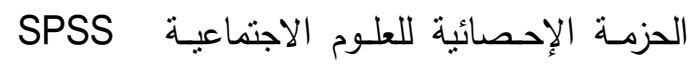
اللنحقق من مدى إمكانية تعميم النتائج التي سيتم الأحة

جدول رقم (1)

معامل الثبات ألفا لأبعاد الاستبيان

(من إعاد الباحث) الإماد

\begin{tabular}{|c|c|c|c|}
\hline ناتج معامل الثبات & عدد العبارات & 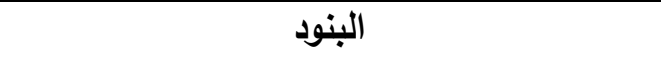 & r \\
\hline$\cdot \wedge 1$ & $\Lambda$ & المعايير الخاصة بمقدة المساق وملامحه العامة & .1 \\
\hline$\because v \leq 9$ & $\bullet$ & أهداف التعلم و الكفاءات &.$r$ \\
\hline.$\wedge \bullet$ & 0 & التقيم والقياس &.$\mu$ \\
\hline$\cdot \wedge r q$ & $r$ & المحتوى التعليمي &.$\varepsilon$ \\
\hline $.9 r$. & $\varepsilon$ & تفاعل المتعلمين ومشاركتهم & .0 \\
\hline$\because \vee \wedge$. & 7 & التكنولوجيات المستخدمة & .7 \\
\hline$\because \wedge 0$. & $\varepsilon$ & دعم المتعلم &.$\vee$ \\
\hline$\cdot . \wedge V$. & 0 & إمكانية الوصول &.$\wedge$ \\
\hline
\end{tabular}

النطاق عبر الإنترنت (MOOCs) ، وتمثلت عينـة البحث في ثنلاث منصات تم اختيارها كعينـة قـصدية، هـي منـصات: كورسـيرا Coursera EDX ب بهدف تطبيق معايير جودة التعلم عبر موك الني وضعتها منظمة الثراكات الأكاديمية (Academic Partnerships AP) دراسة إمكانياتها التقنية، واستراتيجياتها في مجال برامج موك، حتى يمكن الإفادة من تجاربها عند التخطيط لمنصة موك العربية. وقد تم تطبيق

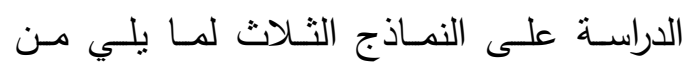

ويتضح من خـال الجدول رقم (1) أن

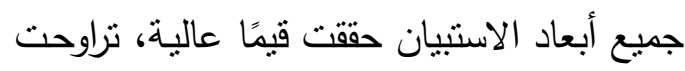

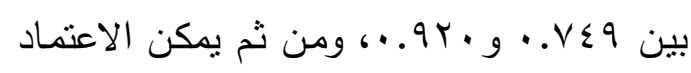
عليها في تعميم نتائج الدراسة. ب- قائمسة المراجعـة (ملحق رقم باتج)، لاستقاء معلومات عن الدنصات الدولية، والمقارنة

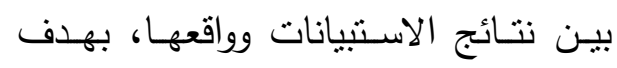
التحقق من دقة النتائج. • / م متمع الدراسة وعينته:

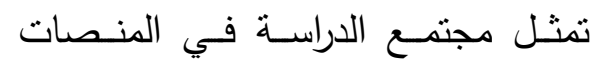

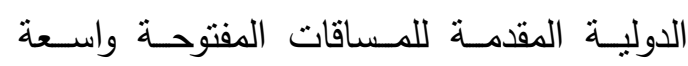


العدد الرابع والخمسـون - 7 •

ع- الاعتماد المؤسسي للشهادات الممنوحة.

0- توافر وتتوع مصادر الدخل؛ حيث تعتمد المنصات في مصادر الدخل على:

أ. الاعم المباشر من المؤسسات الراعية:

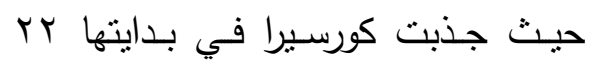

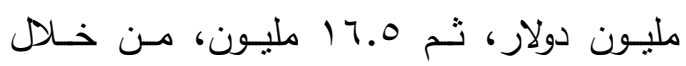

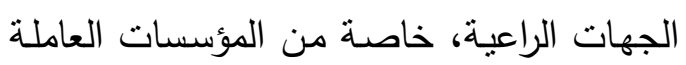
في وادي السليكون Silicon Valley بالولايات

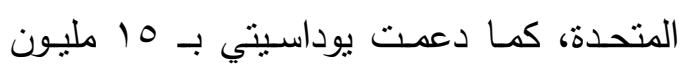
دولار ، من خلال مؤسسيها (فهي تهدف للربح). ب. الأرياح المباشرة من خلال:

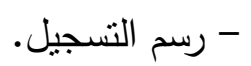
- الدروس الخصوصية - رسم التقييم. - روسن - رسم الثهادات المعتمدة.

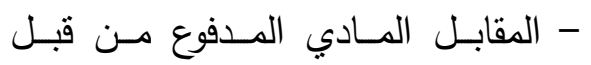
المؤسسات مقابل الدورات المخصصة للعاملين بها.

$$
\text { - توظيف الخريجين. }
$$

ومن ثم تتمتع المنصات بتتوع مصادر

الاخل، مما يضمن لها البقاء والاستمرارية. ج- تتوع اللغات التي تنرجم بها المنصات؛

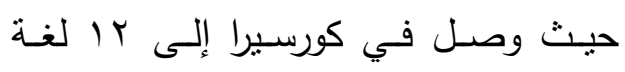
(إضـافة إلى ب r لغـة هـي إجمـالي لغـات

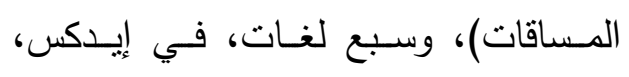

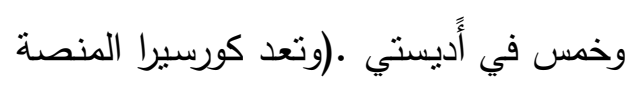

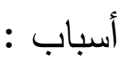

1- الشهرة العالمبـة الواسـعة، وتتوع الشركاء، وتميزهم؛ حيث يفوق عدد شركاء كورسيرا

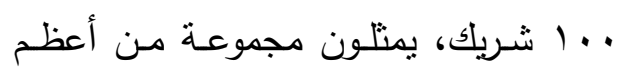

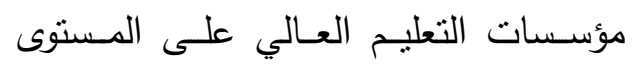

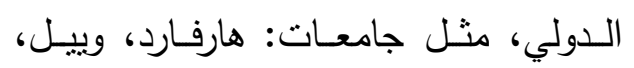

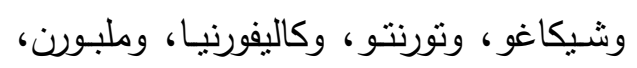

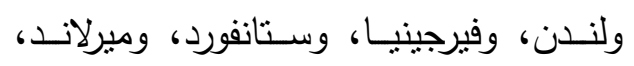

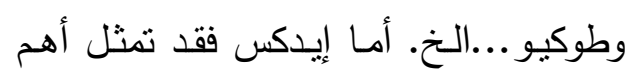
المساهمين فيها في جامعـات: سـتانفورد،

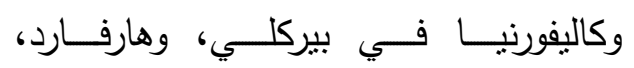

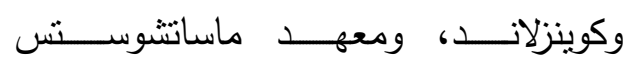

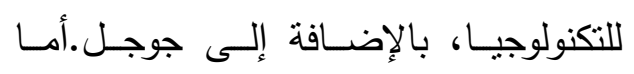
يوداسـيتي فلهـا شـراكات مـع مؤسـسات: جوجل، ونفيديا، ومايكروسوفت، وأوتوديسك.

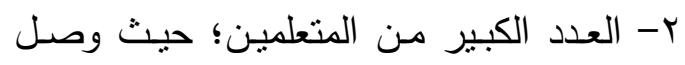
عدد المسجلين في منصة كورسيرا لما يزيد

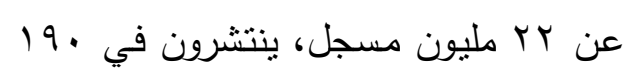
دولة. في الوقت الذي وصل فيه العدد في

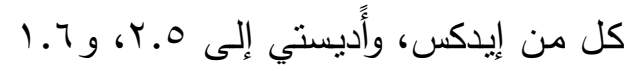
ملايين على التوالي. وتؤكد الأرقام على قوة المنصات. r- العدد الكبير من المساقات الدراسية، وتتوع تخصصاتها؛ حيث وصل عدد المساقات في منصة كورسبرا إلى وصل في منصني إيدكس، واديستي إلى

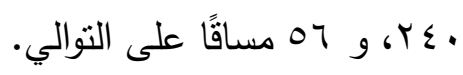




$$
\begin{aligned}
& \text { الوحيدة التي تترجم باللغة العربية، والوحيدة يوداسيتي. } \\
& \text { ع.r اسـتبيان مـن منسـوبي منــة }
\end{aligned}
$$

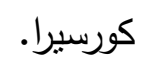

$$
\begin{aligned}
& \text { كمـا تـم اختيـار عينـة قصدية مكونـة } \\
& \text { مـن •r مساقًا مـن المسساقات المتاحـة عبـر }
\end{aligned}
$$

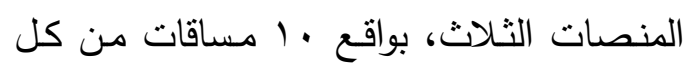

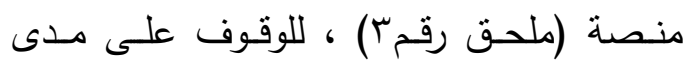

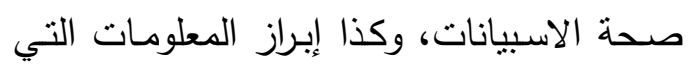

$$
\begin{aligned}
& \text { يمكن أن تفيد منها المنصة العربية التي يقترح } \\
& \text { الباحث تصوراً لها. } \\
& \text { ؟/ • • حدود الدراسة: } \\
& \text { أ. الحدود الموضوعية: }
\end{aligned}
$$

يعني هذا البحث بمدخلين أساسين، تتاول

الأول:الدراسـة النظريـة، وتم فيها تتـاول ماهيـة موك وتطوره، ومكوناته ومبادئه، ونماذجه، وكل

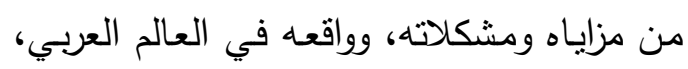
وجهود مؤسسات المعلومات في موك، بتتاول جهـود OCLC، و و IFLA و و .IREX

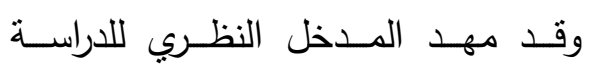
التطبيقية، التي تتاولت: نماذج رائدة لمنصات مـوك، وتطبيـق معسيير مـوك عليها، وتصور

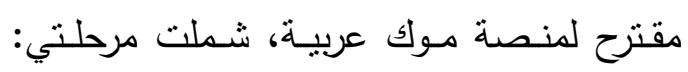
التخطيط القبلي، ومحاور التتفيذ.

$$
\text { ب. الحدود الزمنية: }
$$

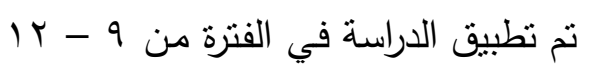

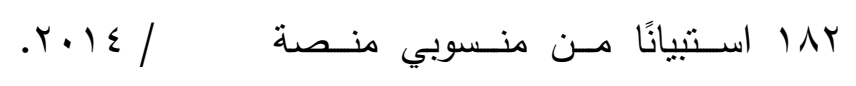
وأكاديمية الأرض Earth Academy.

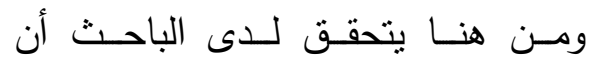

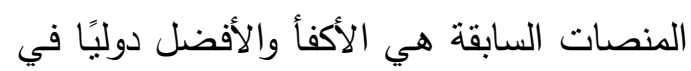

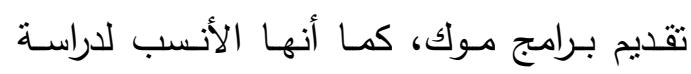
واقعها، والإفادة من تجاربها، ومن ثم فقد وقع بـ عليها الاختيار للدراسة. تم طـرح معـايير مـوك التي وضـعتها منظمة الشراكات الأكاديمية، في صورة استبيان، تم إرسـاله إلـى منسوبي المنصات الثـلاث،

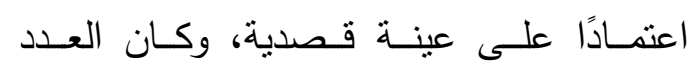
الإجمالي للاستبيانات التي تم تلقيها، وكانت عناصر إجاباتها كاملة، كما يلي:

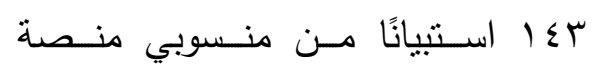
أيدكس. - n - n 
العدد الرابع والخمسـون - 7 •

العربي"، الذي عقد بجامعة بني سويف

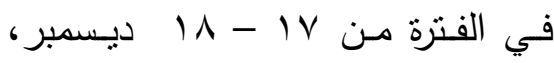

$.5 r \cdot 14$

جـ- المؤتمـر الـدولي الثـاني للتعلـم عـن

بعد :"التعلم عن بعد في الجامعـات

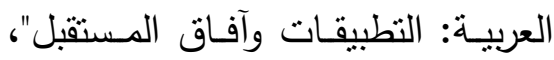

الذي عقد بجامعة بني سويف في الفترة

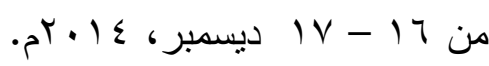

ד- إنتاجهـ لمقرر إلكتروني، وتفعيله لـه على

مدار الأعوام الثلاثة الماضية.

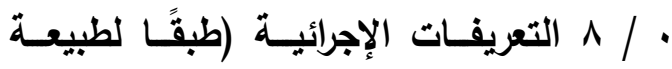

$$
\text { البحث الحالي): }
$$

مساق: برنـامج تعليمسي تفـاعلي مفتوح

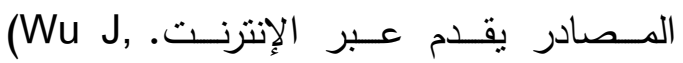

Tennyson RD, Hsia T, 2010)

المسـاق المفتوح واســع النطـاق عبـر

Massive Open (MOOCs) الإنترنــــــــ

Online Courses

التعلم عـن بعـد، يستخدم الإنترنـت كأسـلوب

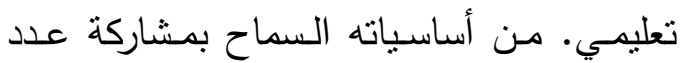

ضـخم مـن المتعلميـن، وخلـق ميـدان نقـاش

وتخاطب تعليمسي بين المششاركين مـن طـلاب

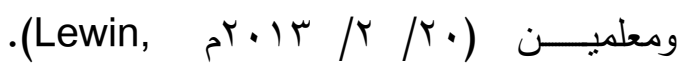

Tamar,

: Distance Learning التعلم عن بعد

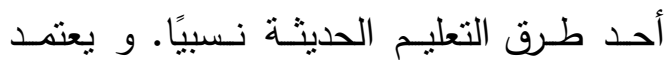

مفهومه الأساسي على وجود المتعلم في مكان
V/.

توافرت عدة عوامل سـاعدت على إتمام

الدراسة، تمنتل أهمها فيما يلي:

1- الاشتراك في مشروع تتافسي قومي بعنوان:

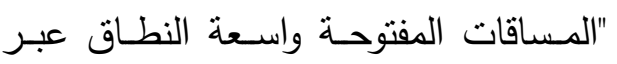

الإنترنت: نحو منصة عربية للتعليم العالي".

r- تلقي الردود من منصـات مـوك التي قـام

برراسـلتها، وهــي: كورسـيرا- أديـستي-

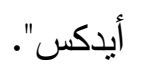

r- إدارة الباحـث لمركز التعليم الإكترونسي،

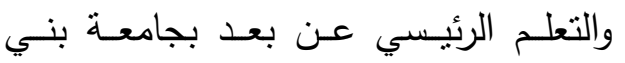

$$
\text { سويف. }
$$

ع- حضور مؤتمر موك والتعليم العالي، الذي

عقد بمقر المركز القومي للتعليم الإكتروني

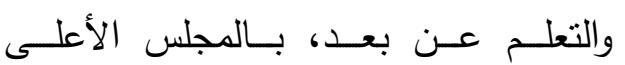

للجامعات، يوم 0 يونيو ع ( • بم.

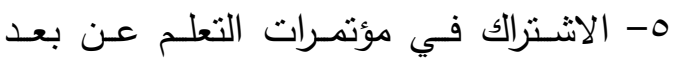

الدولية التالية:

أ- المؤتمـر الدولي للتعلم الاككتروني في

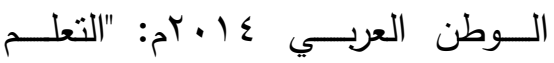

التشاركي في المجتمع الشبكي"، الذي

عقدتـهـ الجامعــة المـصرية للتعلـــ

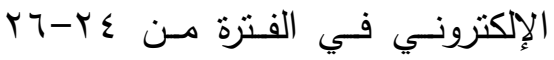

$$
\text { يونيو ع المبرج }
$$

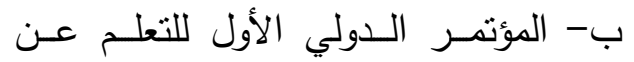

بعد :"التعلم عن بعد ودوره في نطوير

منظومـة التعليـم الجـامعي بالوطـن 
(Schwartz, مؤشـرات نجــاح المـساق).

.Meredith.,10/5/2013)

r - دراسات موك والملكية الفكرية:

في دراسـة لـ Carmen Kazakoff

ناقتث الباحثة ماهية موك الدور الذي يمكن أن

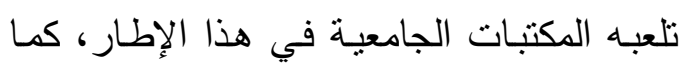

تتاولت قضية شـائكة، وهـي قضية الملكيـة

الفكرية في برامج موك. وانتهت الدراسة إلى أن

هناك بعض القضايا التي يجب على المؤسسات

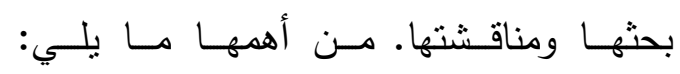

(Kazakoff, Carmen, 2014)

أ. القيود المختلفـة لحقوق الطبـع والنشر

والـتي قـد تتطبـق على مـواد دراسية

مختلفـة، فمحتوي المـواد السمعبصرية،

والتحميل تخضع لقانون حق المؤلف.

كما أن أعضاء هيئة التدريس في حاجة

إلى إدراك عدم قدرتهم على استخدام هذه

المـواد المحميـة مـن قبـل طـرف ثالث، إلثا،

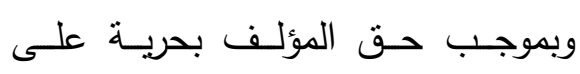

الإنترنت كما هو الحال في صفوفهر.

ب. الفجوة المعرفيـة لحقوق المؤلف التي

تتعلق بأنشطة التعليم والتعلم التي تتم في

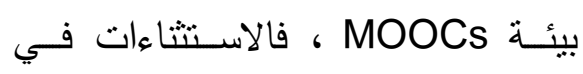

قانون حق المؤلف (الأمريكي) تسمح

بعروض جيدة للمواد التعليميـة بموجب

البند رقم (1) و (Y) في المسادة رقم

• 11 مـن قـانون حـق المؤلف، وهـي
بعيد جغرافيًا عـن المصدر؛ الذي قد يكون

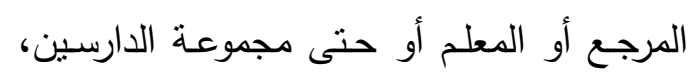

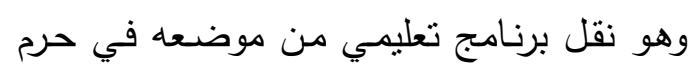
مؤسسة تعليميـة ما إلى أمساكن متفرقة جغرافيًا. ويهدف إلى جذب طلاب لا يستطيعون تحت تعليه الظروف العادية الاستمرار في برنامج تعليمي (Honeyman, M; Miller, G., تقليــدي Dec., r...r) • / الدراسات السابقة والمثيلة: أولاًا الدراسات النظرية:

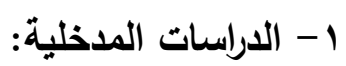

في دراسـتها المعنونـة:"فرصـة المساقات

المفتوحة: دعم فرص المكتبـات "، استعرضت

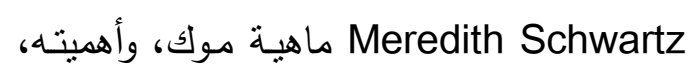
ومزايـا اسـتخدامه فـي المجـال، ومتطلبـات اسـتخدامه، وضـرورة مواكبـة المكتبـات لهـذا لهـات التوجه، مع أهمية وضع معايير لـ موك، وانتهت وضت مورة الدراسة باستعراض مساق دراسي متخصص في

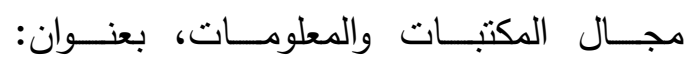
Michael مقدم من "Hyperlinked Library" Stephens والمعلومـات، بجامعسة ولايـة سـان جوس San José State University (SJSU) سجل به نحو .0 متعلم، وأكدت الدراسة على له ضرورة خوض تجارب مشابهة، وأوصت بأهمية

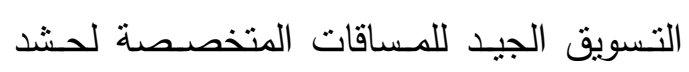
أكبر قدر مـن المتعلميـن المسجلين (كأحـد 
العدد الرابع والخمسـون - 7 •

في دراسـة اسـتهدفت تتبـع تصورات المستهلكين للمعلومـات لنحو عقد مـن الزمن، توصل OCLC إلى عدد من الحقائق، تمثل بعضها فيما يلي:

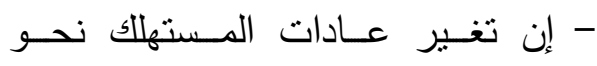
اسـتهلالك المعلومـات، وتحولـه نحسو اسـتخدام تقنيـة MOOCs في ظـل ارتقاع تكاليف التعليم الجامعي، سيعيد تثبيـت التوقعـات السابقة، وسـيحدث تغييرات دائمة في التعليم والتعلم مدى الحياة.

- يمثنل تحـول احتياجـات وتفهيلات المستنهلكين فرصسة جديـدة للمكتبـات لتقديم كل الخدمات وتوفير سبل الراحة التي مـن شـأنها أن نزيــ مـن تأثنـر

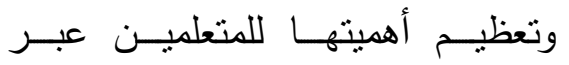
الإنترنت.(OCLC, 25 / 6 / 2014)

وفي بحـث اسـتهدف المقارنـة بيـنـ المحاضـرة المباثـرة (Online) وتقنيـة البـث الإككتروني (البودكاست) (كتقنية يتم توظيفها في

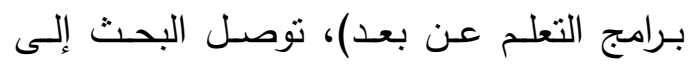
التفوق المذهل لتقنية البودكاست وذلك للأسباب النالية: - 20 - n أ. إمكانيـة اسـتخدامها أكثر مسن مـرة

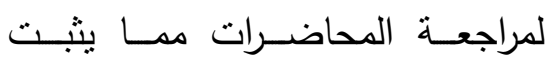
المعلومات لدى الدارسين. ب. تحريـر المتعلميـن مـن قيــ تدويـن
تقتصر على المؤسسات التعليميـة غير الربحيـة، ولا تتطبـق على المؤسـسات MOOCs.J المقدمة

M. لا يمكن لمطوري منصات MOOC

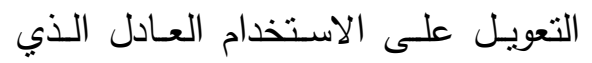
يحميهم، والأهم من ذلك أن الاستخدام

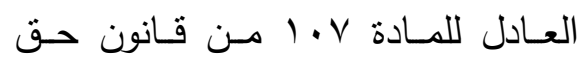
المؤلف تتطبق على MOOCs ومسع ذلك، فـإن تحديد مـا يشكل الاسـتخدام العـادل للمـواد المحميـة مـن الأمسور الصعبة، فالتحديات التي تتشأ في بيئة الإنترنت هي أكثر بكثير مما هو الحال في الحرم الجامعي. وفي دراسـة لـ Nora Almeida حول المكتبات وموك، وواقع حقوق الملكيـة الفكريـة، انتهت الدراسة إلى أن عدد من القضايا القانونية والأخلاقية في أنظمة MOOCs لازالت تقع في

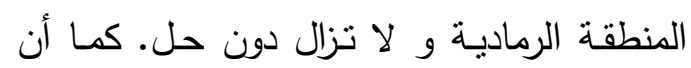
بعض القـوانين واللـوائح التي تتعلـق بيئـات MOOC الدراسية يتم بثها في جميع أنحاء العالم، من لن أجل الربح، إلى مؤسسات ومستهلكين ومتعلمين، لأن

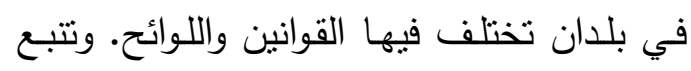
من هنا مشكلة الملكية الفكرية في بيئة موك. .Nora( .Almeida, 21 / 8 /2013) ثانياً الدراسات الميدانية: 1- دراسة أهمية موك: 
(BSRG, . كد أدنى من خلال إحدى المنصات

وفي دراسة قام بها Dan Colman بالتطبيق

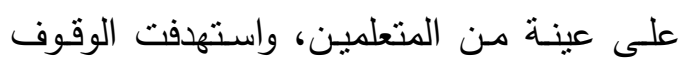
على أسباب تسربهم من برامج موك، انتهـ الدراسة إلى أن أهم هذه الأسباب - طبقًا لآرائهم

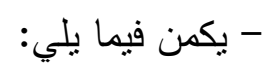
- الكم الكبير من الوقت المستتفد. - الكم الكبير من المادة العلمية.

- ضعف إمكانيات المادة العلمية، مقارنة بنظيرتها التقليدية.

- الملل من الفيديو التعليمي، خاصة لونهائ لو كان سئ التصميم.

- سوء تصميم بعض المساقات.

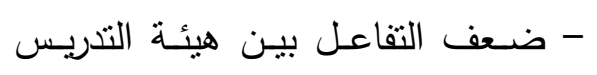
والمتعلمين.

- عدم تأهل بعض المتعلميـن لعمليـة تقييم الأقران.

- وجـود بعض التكاليف الخفيـة، مثل

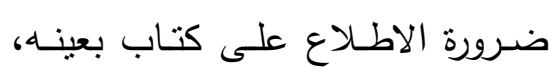

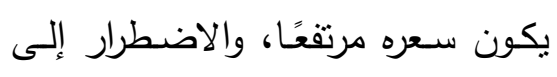

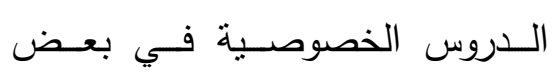
الأحيان.

- صعوبة الاختبار الن Dan, 2014)

(Colman,

وفي دراسـته المعنونـة: "النجـاح فـي

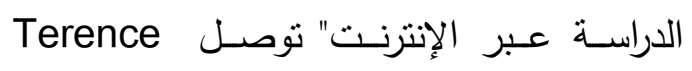

الملاحظـات التي قد تصيب بعضًا منهم بتشتت الذهن وضياع التركيز . ج. تمنح المتعلمين مبزة التعلم بالسرعة التي تتاسبهم، وتلقي هذه الميزة قبولاً

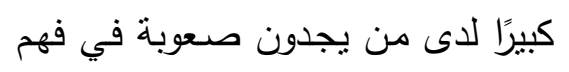

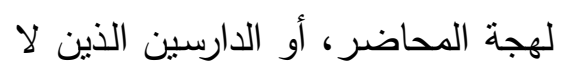

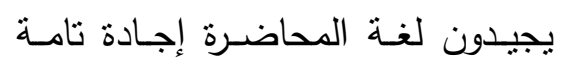
بدرجة تمنحهم الفهم السريع لمحتواها.

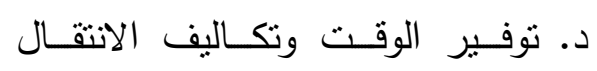
للاســتماع للمحاضــرة المباشــرة. (Smithy, Kate, 2014) r ب. دراسات المتعلمين: في دراسـة حديثـة أجريـت أوائل عـام

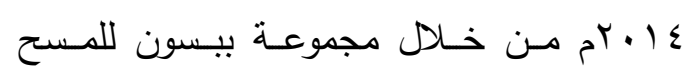

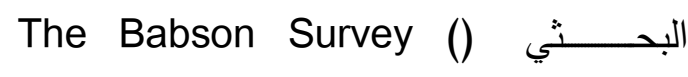
Research Group BSRG عينـة عـشوائية مسن الجامعـات والدارسـين الأمريكيين، أسفرت عن النتائج التالية: - 00 \% مـن المؤسـسات العلميـة قيــ البحث لم تقرر بعد خوض تجربة موك. - T.r مساقات دراسية، أو أنها في طريقها لإنشاء منصة.

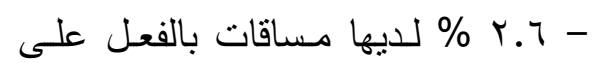
احدى المنصات. كما أسفرت الدراسة عن أن بس \% من الطلاب بالجامعات قيد البحث حصلوا على مساق واحد 
العدد الرابع والخمسـون - 7 •

لمنصة كورسيرا، من طلاب المرحلة الجامعية،

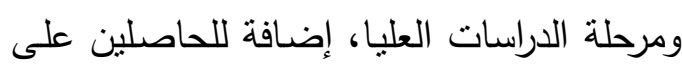
درجة الدكتوراه، انتهت إلى وجود أربع فئات من المتعلمين، هم:

- المتممون، وهم المتعلمون الذين شـاهدوا معظم المحاضـرات، وشـاركوا في وهي معظم التقبيمات.

- المراجعون، وهم الذين شـاهدوا معظم

المحاضـرات، ولكـن شــاركوا فـي قليـل مـن فـن التقييمات.

- المارون، وهم المتعلمون الذين انخفض

أداؤهم بسرعة بعد مرور الأسبوع الأول.

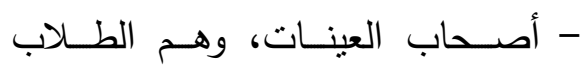

المسجلون، إلا أنهم لم يشاهدوا إلا نذرًا

$$
\text { قلياًً من المحاضرات. }
$$

وانتهت الدراسة إلى النتيجة التالية:

وفي دراسـة لهابر جوناثنان، استهدفت

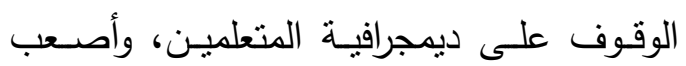
الأنشطة التعليمية التي تواجهرم، في مساقات
Loose، من خـلال دراسـة مسحية تم تطبيقها على عينة من المتعلمين المتقوقين الذين اجتازوا

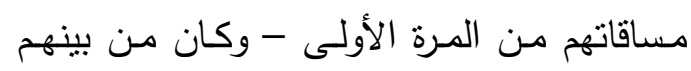
متخصصون في مجال المكتبات والمعلومات - مهن إلى أن أهم ما يميزهم تمثل فيما يلي: Loose, Terence, 2014) - الاستقلالية (فالمتعلم قائد نفسه في - التتظيم. - التواصل (مع الآخرين عبر الشبكة). - إدارة الوقت بشكل جيد. - الحرفية في مهارات الحاسب. - عـدم الـتردد في الأسـئلة وطلـبـ فئب المساعدة. - الالتزام الجيد بالمواعيد(خاصـة في رفع الأنشطة والمهام والواجبات المطلوبة).

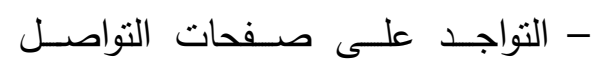
الاجتماعي.

وفي دراسـة أجريـت بجامعـة سـتانفورد، وطبقت على عينة مـن المتعلمين المنتسبين

جدول رقم (r)

فئات المتعلمين في كورسبرا

\begin{tabular}{|c|c|c|c|c|}
\hline أصحاب العينات & المارون & المراجعون & المتممون & الطلاب الدرجة \\
\hline$\% r q$ & $\%$ r^ & $\% r v$ & $\%$ & ما بعد الاكتوراه \\
\hline$\% \vee \leq$ & $\%$ Ir & $\% \wedge$ & $\% 7$ & الاراسات العليا \\
\hline$\% \wedge$. & $\% 9$ & $\% 0$ & $\% 9$ & لمرحلة الجامعية \\
\hline
\end{tabular}




$$
\begin{aligned}
& \text { - ومن حيث البيانات الثخصية: } \\
& \text { بr \% يعيشون في الولايات المتحدة. } \\
& \text { \% \% من البيض. }
\end{aligned}
$$

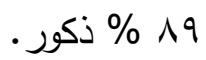

$$
\begin{aligned}
& 9 \text { \% حاصلون على الدكتوراه. } \\
& \text { - ومن حيث الأعمار : بل }
\end{aligned}
$$

كان أقل الحاصلين على المساق عمرًا

$$
\text { (V) }
$$

الأكبر ع عامًا، أمسا أكبر المسجلين

$$
\text { فبلغ ^^ عامًا. }
$$

المتوسط هب عاماً.

r. دراسات هيئة التدريس:

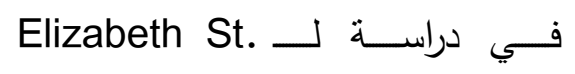

Germain

الأخطـاء التي تقـع فيها هيئة التدريس عند

تصميم الدورات، انتهت الباحثة إلى أن أهم هذه فئه

الأخطاء يتمنل في:

-اعتقاد بعض الأساتذة أن الغايـة هي في

تحميل النصوص فقط؛ فعليهم إعادة

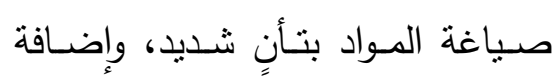

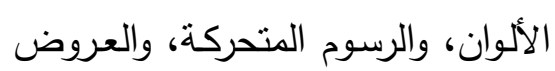

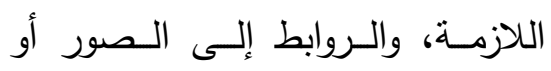

المواقـع التاريخيـة، أو حتى المناظـر

$$
\text { الحديثة للشوارع على جوجل. }
$$

- نظام إدارة المساق الدراسي يقود تفكير

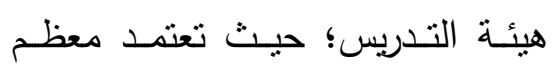

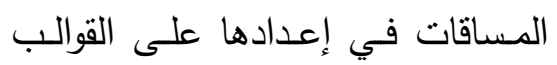

مـوك (دون أن تحــدد الدراســة المنـصات المستهدفة)، انتهت إلى

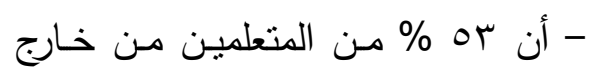
الولايات المتحدة.

- أن ov \% من إجمالي عدد الطلاب

لا تمثل اللغة الانجليزية لغتهم الأم.

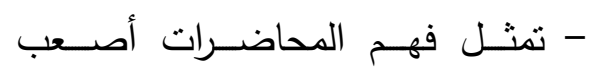

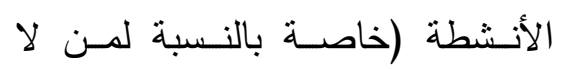

يجيـدون الإنجليزيـة)، تليهـا أســئلة

$$
\text { الاختيار من متعدد. }
$$

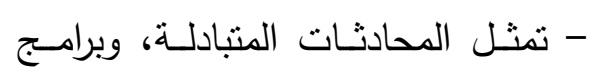

(Bombardieri, الشات أمتع الأنشطة النشات

Marcella ,14 April 2013).

وفي دراسـة قـام بها Tucker Balch

ونفذت في ربيع rا ـ rم، واستهدفت الوقوف درس

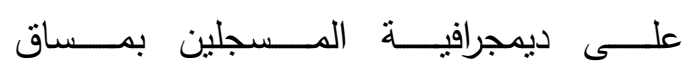

Computational Investing, Part I

من خلال منصة كورسيرا، توصلت الدراسة إلى ما يلي: ( Tucker , 2013 Balch,

- بلغ إجمالي عدد المسجلين في المساق

ros19

- بلـغ عدد من شـاهدوا ملفـات الفيديو \% 10711

- بلنغ عدد من حاولوا حل الاختبارات

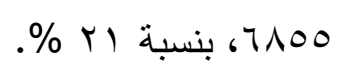

- أما من أنت المساق، فقد بلغ 9 \% من

$$
\text { إجمالي المسجلين. }
$$


العدد الرابع والخمسـون - 7 •

الرخاء والاستقرار المادي، نتيجة لكون

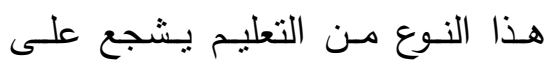

التخـرج، وبالتـالي زيـادة الخيـارات

الوظيفية وعدم الانزلاق في بيئة تولد

المشاكل الاجتماعية في وقت لاحق.

- يسجع إعطـاء الطـلاب مزبـدًا مـن

الخيـارات لاسـتكمال المهام المدرسية إهية

ويساعد كثيرًا منهم على اسـتكمال

تعليمهم.

-رغـم أن المـدارس النرويجيـة مكتظــة

بالتقنية، إلا أنه لا يتم استخدام أدوات

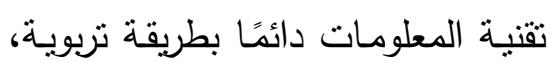

$$
\text { ويفتقر المعلمون إلى التدريب. }
$$

- يستخدم كثير من المعلمين منصسات

التعلم وغيرها من الأدوات للقيام بمهام

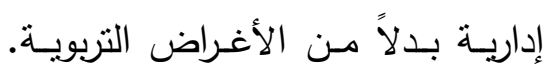

(Krumsvik, Rune Johan,

$$
\text { . 2012) }
$$

ع. الدراسات العامة:

في دراسة مسحية أجراها مشروع الحوسبة

الأكاديمي Campus Computing Project بالتطبيق على مديري المعلومات التنفيذيين في 0 01 كلية وجامعة حكومية، وخاصسة في أنحاء

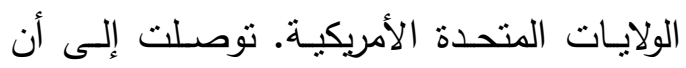
التقنيـة في تطـور مستمر داخـل المؤسـسات الأكاديمية - من خلال المساقات المفتوحة عبر الإنترنت والانتشار المتزايد في الأجهزة الكفية -
المعدة سلفاً، ويقوم المعلم بملئها.

- الإصــرار علـى التحكـم فـي البيئة

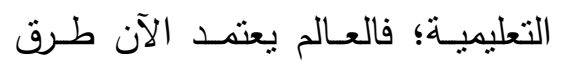

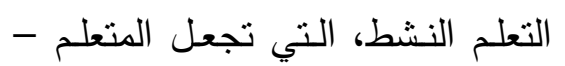

وليـس المعلـم - محسـور العمليــة

التعليمية.

- التركيز على الاستهلاك المعرفي بدلاً

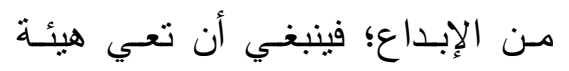

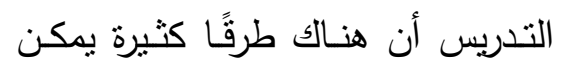

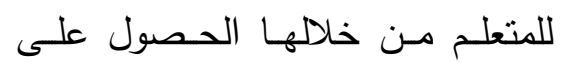

المادة التعليمية.

- تجاهل طرق تعلم الطلاب من بعضهم البعض؛ فأغلب المساقات الدراسـية

على الإنترنت نتخذ شكل حوار ثنائي

بين الطالب وهيئة التدريس، وتتجاهل

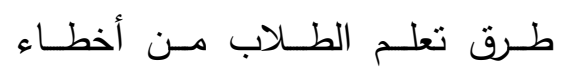

زملائهــم، وأفكـــارهم، ومسـشاركتهم.

(Germain, Elizabeth, 2014)

وفـي دراسـة اسـتهدفت بحـث: "واقـع

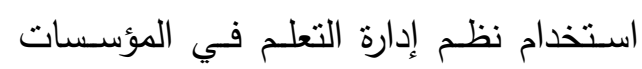
التعليميــة المعتمــدة علــى التعلــم عبــر

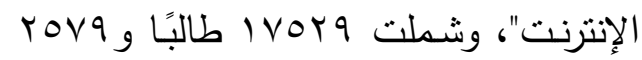

مـن المعلمين في المـدارس الثانويـة العليـا النرويجية، أمكن التوصل إلى ما يلي:

- يــؤدي اسـتخدام تقنيــة المعلومــات

والاتصالات، إلى حصول الطالب

على فرص أعلى ليعيش حالـة من الن الـن 
- يفضل ع \& من إجمالي المتعلمين

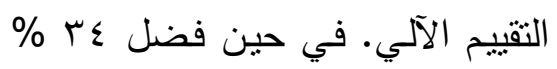
تقبيم الأقران.

- يفضل 9V \% من المتعلمين مشاهدة

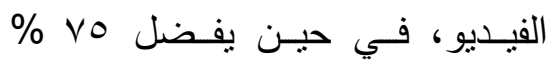

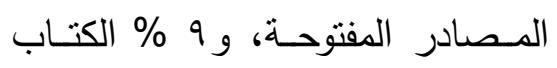

الورقي، وه \% الكتـاب الإكترونسي.

(Kolowich, Steven ,26 March

أفاد الباحث من الدراسات المثيلة والسابقة

في التأكيد على صـحة ومسصداقية مـصادر المعلومات التي استتد إليها في الدراسـة الحالية، وقد توصـل - مبدئيًا - إلى عدم وجود دراسـة سابقة طرقت التخطيط لإنشاء منصة موك عربية

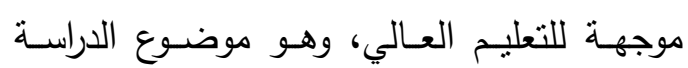

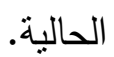
ا 1 ـ الاراسة النظرية: / / 1 ماهية (MOOCs):

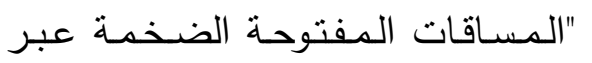

الإنتـرنتـ" أو "الـمقررات الإلكترونبـة ذات

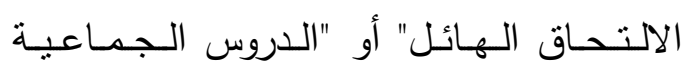

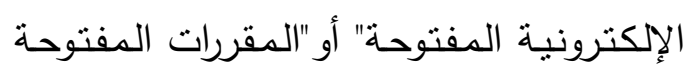

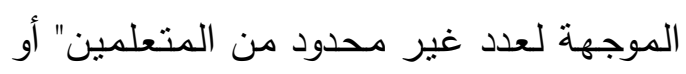

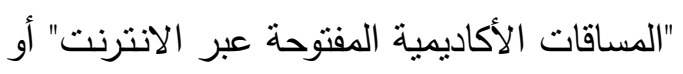
"الدورات الضخمة واسعة النطاق المتاحة عبر الاند الإنترنت" أو "المناهج الإكترونية المفتوحة والته

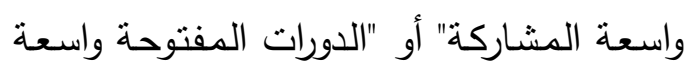
النطاق عبر الإنترنت" أو "موك" أو "مووك" أو
وكـان ترتيـب أولويـات تقنيـة المعلومـات فـي المؤسسات التي يعملون بها كما يلي:

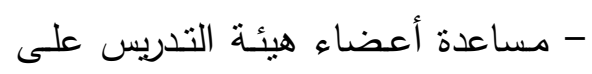

دمج التكنولوجيا في العملية التعليمية،

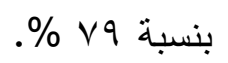

- توظيف واستبقاء مسئولي تكنولوجيـا

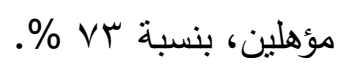

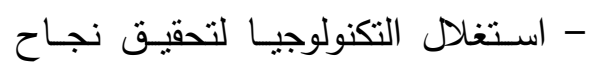
الطلاب، بنسبة VY \% \%

- توفير التعليم عبر الإنترنت، بنسبة لغنبة (MacKay, R.F. ,11 \% т April 2013) وفي دراسة ستيفن كوليش التي استهدفت

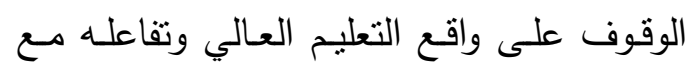
موك، وطبقت على منصات إيدكس، وأديستي، انتهت الدراسة إلى النتائج التالية: - انخفاض عدد ساعات تعاطي الأساتذة

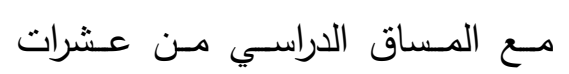

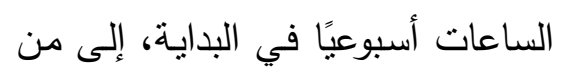

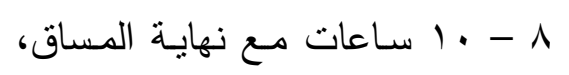
وأرجع الباحث هذا إلى تمرس الأساتذة

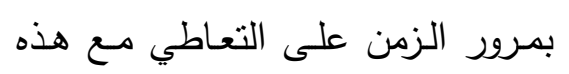

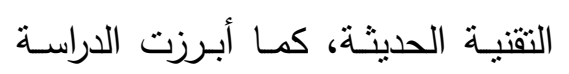

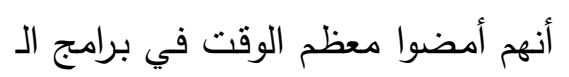
"شات".

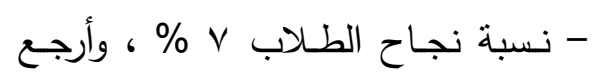
السبب إلى عدم استمرارية المتعلمين في المساق المسجلين فيه. 
العدد الرابع والخمسـون - 7 •

يحـثث في المؤسـسات التعليميـة

$$
\text { التقليدية. }
$$

- أن المساق مجاني الانتساب للجميع. مع أنه - في بعض الحالات - قد تفرض بعض الرسوم في حال اعتماد

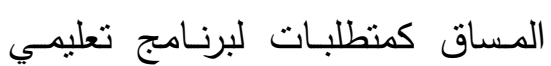
معتمد.

عبر الإنترنت : لها المدلولات التالية: - مشاركة غير محدودة بزمان أو مكان. - التفاعل بين متعلمين افتراضيين وفي معظم الأحيان - دون أي معرفة شخصية بينهم.

- اعتمـاد التقنيـة - وبخاصـة الحاسـب

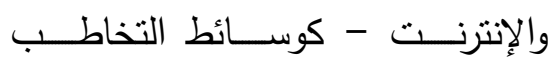

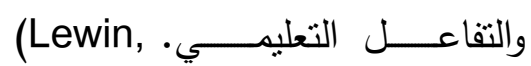
(Tamar , 20 /2/ 2013) (Pappano, Laura, 4 / 11 / . 2012),

وتعتهـد بـرامج مـوك على نظـام إدارة

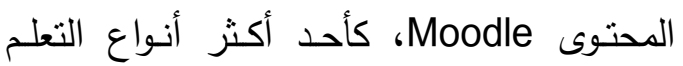
فعالية، والتي تعزز التفاعل بين المتعلم وأقرانه والمتعلم والمحتوى، والمتعلم وهيئة التدريس.

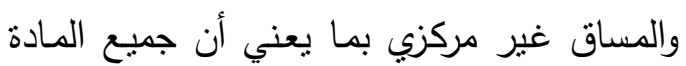

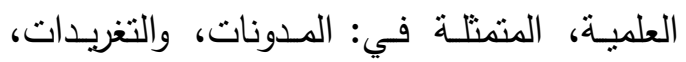
ومقاطع الفيديو، والمقالات المرسلة من خلاله مرتبطة مع بعضها البعض لتكون مساقًا متكاملاً،

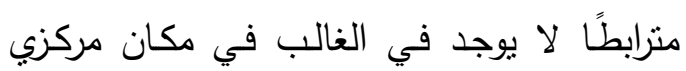

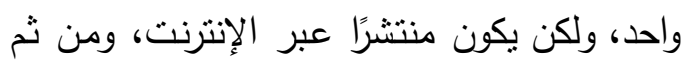

جميعها مصطلحات تختلف رسمًا، ولكنها تعبر عن مضمون واحد، وهو المساقات المفتوحسـة واسعة النطاق عبر الإنتــــــت (MOOCs)

وهي اختصار لـ Massive Open Online .Courses والمسساق المفتوح واسـع النطـاق عبر الإنترنت هو مساق تعليمي حديث وناشئ في واني مجال التعلم عن بعد، يستخدم الإنترنت كأسلوب

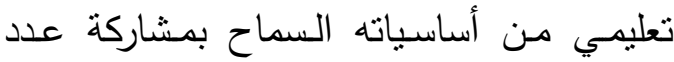

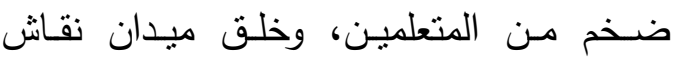

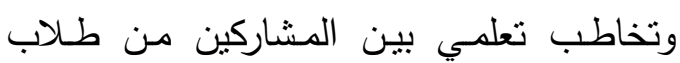
ومعلمين. وهو ترجمة حرفية للمصطلح الإنجليزي : (Massive Open Online أو MOOC ولكل كلمة في المصطلح مدلولها Course). الذي يمكن تتاوله فيما يلي:

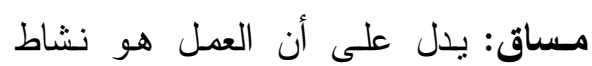
تعلمي، يهدف إلى دفع المتعلمين إلى اكتساب هن معرفة جديدة بشكل أساسي وهو بعتمد الهيكلية

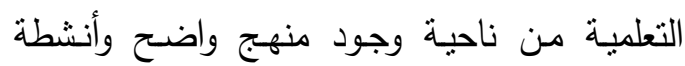
وتقييمات ومحاضرات. واسع النطاق :يدل على عدد المتعلمين الكبير الضروري لنجاح عملية التعلم، والذي يصل إلى على

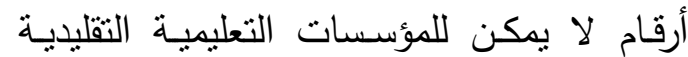
التعامل معها. مفتوح، يدل على مدلولين: - أن المساق مشاع للجميع دون أب لي شروط مسبقة لقبول المنتسبين، متلما 
أمســا التعلـم الإلكترونسيـ Electronic

learning النطبيقات والعمليات مثل: التعلم المعندـ على التى الحاسب الآلي، والـصفوف الرقيـة، والإنترانت وتـشارك الملفـات ونقـل الدحتـوى مـن خـلال

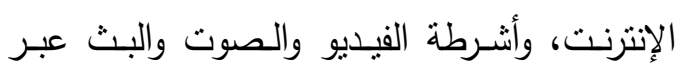

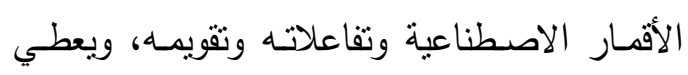

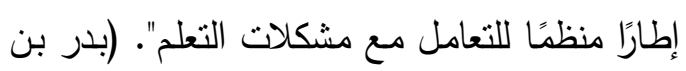
عبد الله، 0. 두).

وهناك درجة من التداخل بين برامج موك أبكان

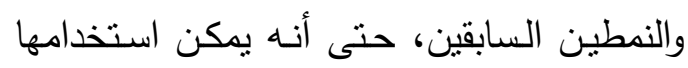

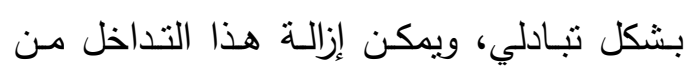
خلا إبراز أوجه الاختلاف التالية: 1- أوجه الاختلاف بين برامج موك والتعليم عن الإن التهن بعد.
لا نوجد طريقة موحدة، يسير عليها جميع

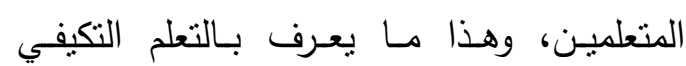

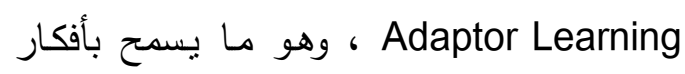

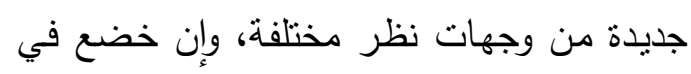
النهاية للمنصة التي أطلقت المساق. العلاقةـة بيـن مـوك والتعلم عن بعد والتعليم الإلكتروني:

يعـرف التعلـم عـن بعــ Distance

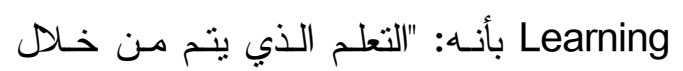

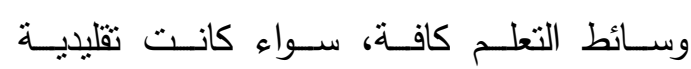

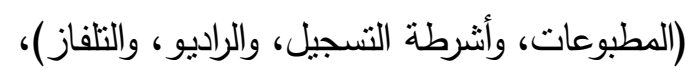

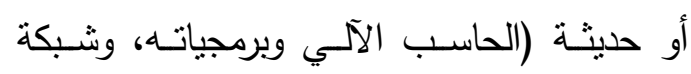
الإنترنت، والقنوات الفضائية، والمحمول)؛ حيث

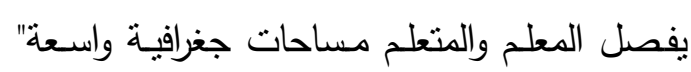
.(Sherry, L. , Y. . 9)

جدول رقم (ץ)

أوجه الاختلاف بين برامج موك والتعلم عن بعد

\begin{tabular}{|c|c|c|c|}
\hline التطلم عن بعد & موك & & p \\
\hline القادي. عددأ، خاصة مع ارتفاع المقابل & متتوع ، ومتسع، وغير محدد. & المتعلمون & .1 \\
\hline 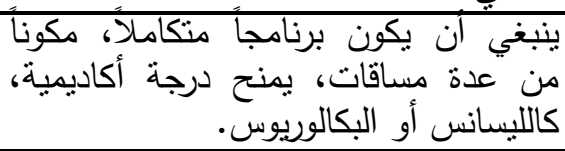 & يمكن أن يكون مساقًا واحدًا. & الدساقات &.$r$ \\
\hline ذو مقابل مادي مدفوع. & مجائًا (تقرييًا) & المقابل المادي & r \\
\hline الجهة الراعية. & هيئة التدريس. & الإنتاج & . \\
\hline بدرجة أقل. & عالية جداً. & التفاعلية & .0 \\
\hline
\end{tabular}


العدد الرابع والخمسـون - 7 •

r. أوجه الاختلاف بين برامج موك والتعليم الإلكتروني.

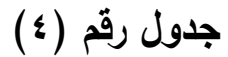

أوجه الاختلاف بين برامج موك والتعليم الإكتروني

\begin{tabular}{|c|c|c|c|}
\hline التعلم الإكتروني (r) & موك & & م \\
\hline الإكتروني، وهد من يدرسون في نفس مجال المقرر & متتوع وغير & المتعلمون & .1 \\
\hline 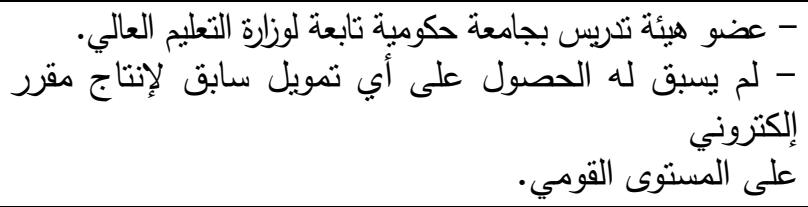 & التخصص & هيئة التدريس & .4 \\
\hline 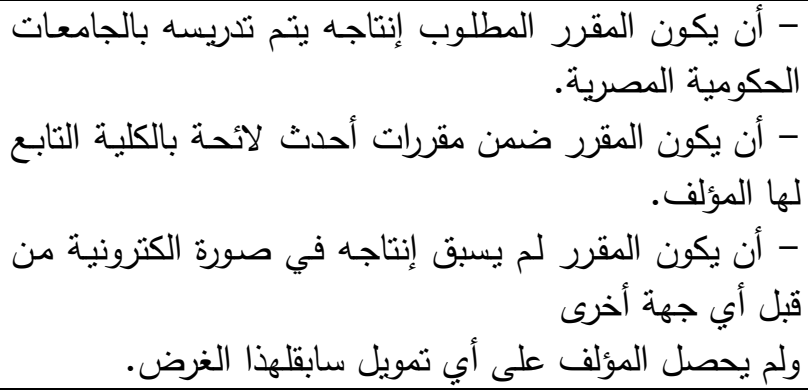 & 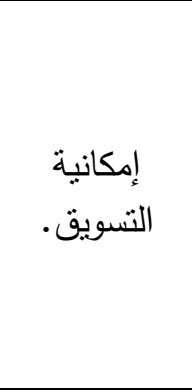 & شروطات & r \\
\hline الجهة الراعية. & هيئة التدريس. & الإنتاج &.$\varepsilon$ \\
\hline هيئة التدريس. & 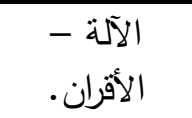 & التقييم & .0 \\
\hline
\end{tabular}

منذ عام •91 ام، حين بدأ انتشار التعلم عن

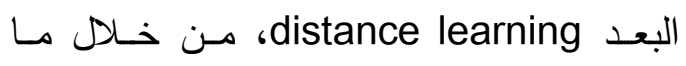
يعرف بـالتعلم بالمراسـلة correspondence courses

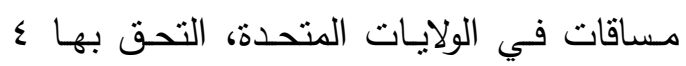

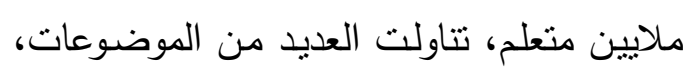

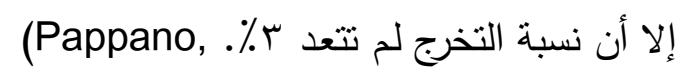

Laura, 4 / 11 / 2012) واكب هذا - وفي العـام نفسه - برامج
ورغم الاختلافات السابقة إلا أن هنـاك

تكاملاً بين الأنماط الثلاثة؛ فتعد برامج موك الافئ

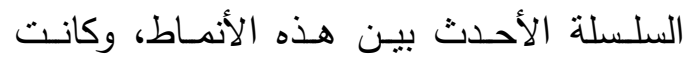
نشأتها نتيجة المزج بين كل من التعلم عن بعد والتعلم الإكتروني من ناحية وشبكات التواصل فئل الاجتماعي من ناحية أخرى.

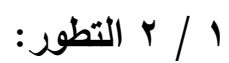
بدأت المساقات التعليميـة، التي طورت لتجذب أعدادًا هائلة من المنتسبين لتعليم العامة 
T · . rم وتبعها مشروع أليسون دوت كوم عام

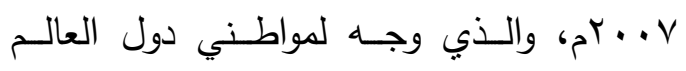
الثالـــثـ. (Wiley, David.,7 / 2012)، واعتمد نظام المجانية. أما أول مساق موك فعلي فقد طرح عام

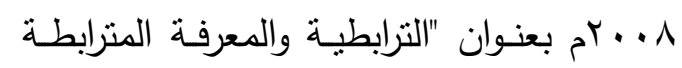
Connectivism and Connective Knowledge"

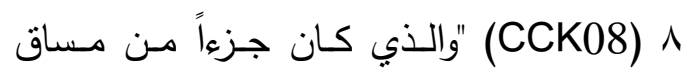
تعليمي في جامعة مانيتوبا، ودرسه جورج سيمنز George Siemens داونـز Stephen Downes . والتــق بــ

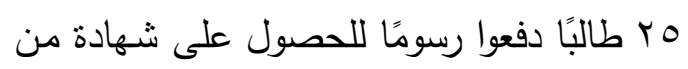

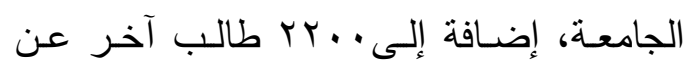

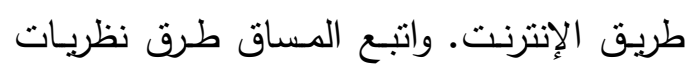
جورج سيمنز حول التعلم الترابطي، والذي نشره

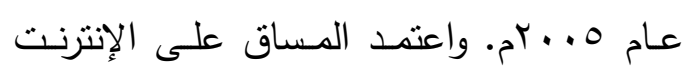

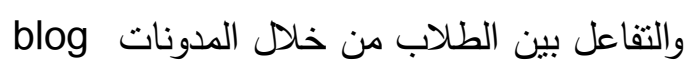

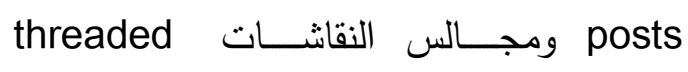
الإكترونيـة، وواجهـة مـودل Moodle (Carr, David الافنراضـــ Second Life F ,20 / 8 / 2013)

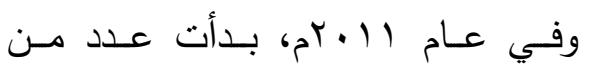

الجامعات المرموقة في تدربس موك لطلابها العاديين الذين ينوون الحصول على شهادتها.

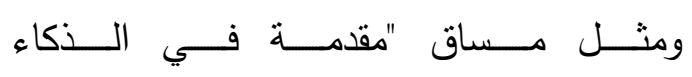

البـث الإذاعي التي بـدأتها جامعـة نيويـورك، ولحق بها عدد من الجامعات المرموقة؛ حيث طلب من المتعلمين قراءة كتب، بينما قام المعلق الإذاعـي بتـدريس الموضـوع. وكانـت ترسـل

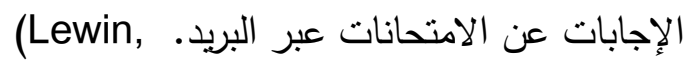
Tamar , 20 /2/ 2013) وانتهت هذه المحاولة بالفشل لصعوبة

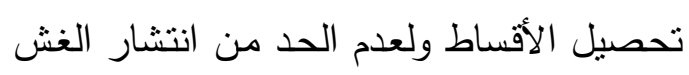
بيـن الطـلاب. وخـلال الحرب العالميـة الثانيـة، اعتمدت الأفـلام لتدريب الملايين على القتال واستعمال الأسلحة في المعارك.

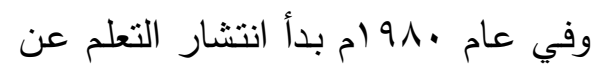

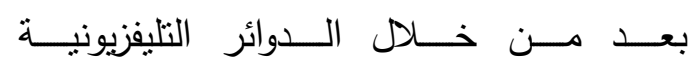
(Zulli ,Floyd,2013)، وكانت بدايـة انتشاره عبر الإنترنت عام 99 ام، من خلادل جيمس وكال

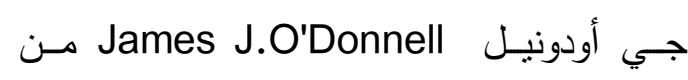
جامعـة ولايـة بنسلفانيا، الذي بـأ في تدريس

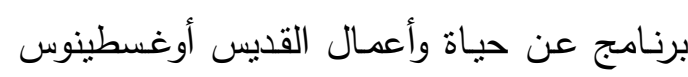
The Life and Works of St. Augustine of Hippo جوفر و البريد الإكتروني، وجذب هذا البرنامج أكثر من · . .0 مشارك من جميع أنحاء العالم . (O'Donnell, James J., 1994) أمسا مـن ناحيـة اعتمـاد الإنترنـت والتعلم

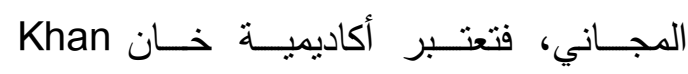
Academy

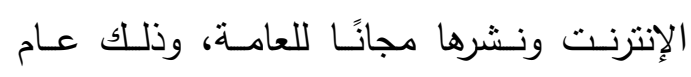


MOOCs وبالتعـاون مـع معهـد جورجيـا للتكنولوجيـا أول درجـة ماجستير عبر مـوك، معاك

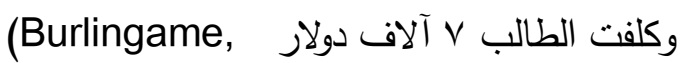

Russ, 23 / 3 /2013)

في سبتمبر عام با • بم، أعلنت EDX شراكة مـع جوجل لتطويـر شـركة EDX، كمنــة (Waldrop, M. Mitchell, مفتوحة المصدر (3 2013 / 13، وقد دخلت موك إلى الدول النامية، والتي كان منها جامعة تايلور بماليزبا

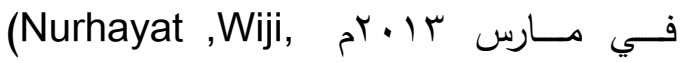
(2013 / 8/ 25/ وجامعة رييكا بكرواتيا في

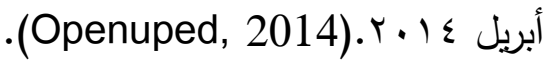

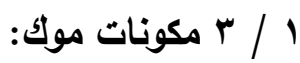
تشمل مكونات موك العناصر التالية: أ. المحتـوى، ويـشمل: مقـاطع فيـديو، كوتهن

$$
\text { وملفات قراءة، وملفات صوتية. }
$$

ب. أنــشطة، وتــشمل: مناقـشنات،

$$
\text { وتكليفات، وتقارير - }
$$

جـ. التقبيمـات، وتـشمل: اختبــارات،

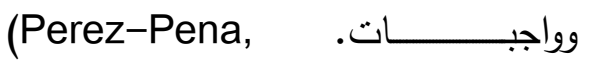

Richard,25 March 2013)

وتتطلب مساقات موك أن يكون المتعلم نشطًا، وليس متلقيًا سلبيًا؛ حيث بيطلب منه المشاركة في المقرر، وبناء ونشر المعرفة، ويحسب لـه درجات على مشاركاته.

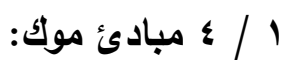
تتمثل أهم مبادئ المساقات المفتوحة عبر
الاصــطناعي" introduction Into Al أول مساق من جامعة خاصـة ، وهو المساق الذي طرحته جامعـة ستانفورد، ووصل عدد الطلاب فيه إلى . . ألف طالب. وإثر نجاح التجربة، أنشأ مدرس المساق شركة سماها يوداستي : Udacity والشائعة. كما أنشئ شركة كورسيرا Coursera التي توفـر للجامعـات العالميـة مجـال طـرح مساقاتها كمشاع لعدد هائل من الطلاب. ويطلق على عام r I ب r عام الـ مـوك نظـرًا لظهـور عـد مـن موفـري هـذه الخدمسة

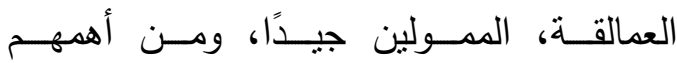
Coursera ارتبط هـذا العـام بانـضمام عـد كبـير مـن وهن مؤسسات التعليم العالي المنطورة - خاصـة في أمريكـا الشمالية - ــ مـوك، والتتي كان مـن أثنرها جامعات: هارفارد، وكاليفورنيا، وبيركلي، وتكساس، وجورج تاون، إضافة إلى كلية وليسلي بطرح مساقاتها التي تعتمد التعلم التقليدي على

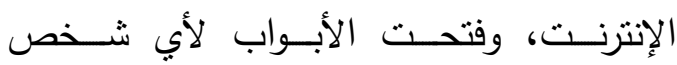
Smith, Lindsey, . بالمـشـاركة مجانــاً $31 / 7$ / 2012) (Pérez-Peña, (Richard.17 / 7 /2012)

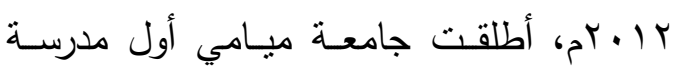
ثانوية على الإنترنت / Troy Onink. 18 / 18 .2012).

Udacity وفي ينـاير آ.rام أطلقت 
وهـو النــوذج الأساسـي للمـوك والذني

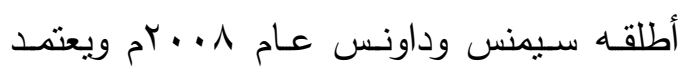

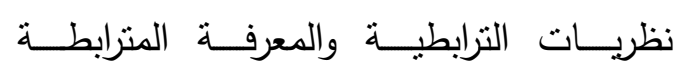
(Connectivism and connected knowledge)

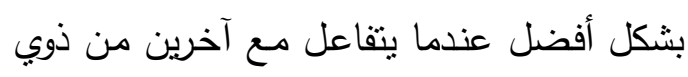

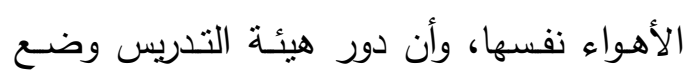
الأطر العامة للموضوع ويترك الأمر للمتعلمين

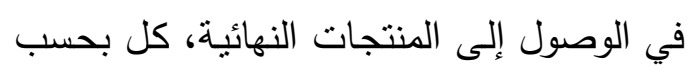

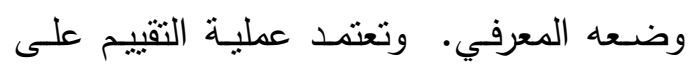
تقييم الأقران. ويمكن لمجموعـات المتعلميـن ولفين

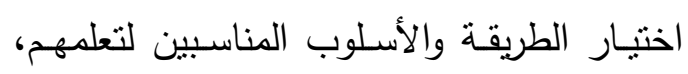

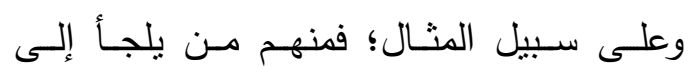

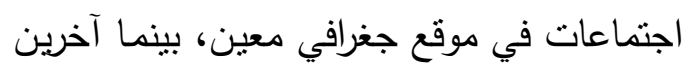
قد يستعملون الوسائط الاجتماعية. ويترك تكوين

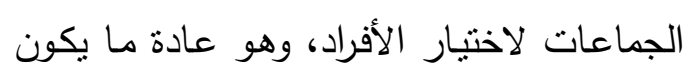

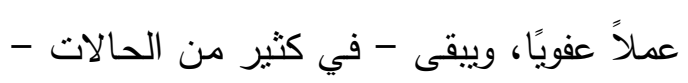
عمل الجماعات نشطًا حتى بعد انتهاء المساق. وفي هذا النموذج من الموك، يكون دور هيئة التبريس ثنانويًا. r. إكس- موك:

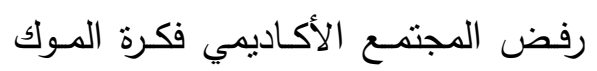
الأساسية لأنها تتعارض مع العديد من أسس العس لكس

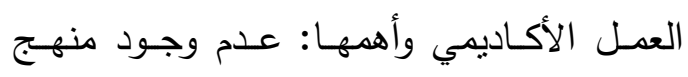

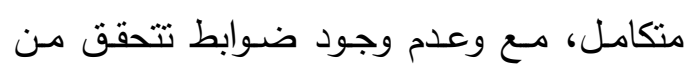

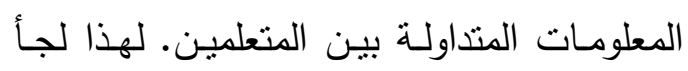
الأكاديميون لنموذج جديد يعتمد طرق النعليم
شبكة الإنترنت فيما يلي:

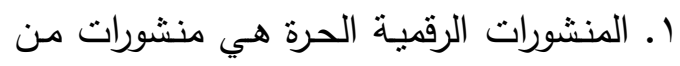
مواد تعليمية عالية الجودة ومنظمة كدورات منهجة. r. متاحـة للاستخدام والتكيف تحت رخصة مفتوحة منل ترخيص المشاعات الإبداعية.

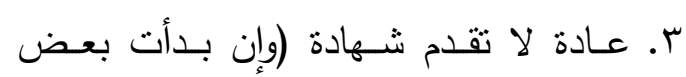

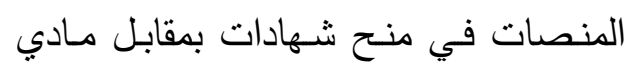
خلا الشهور الأخيرة، وكانت تخطط لهذات بناب مادي

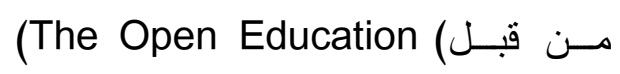
Consortium, 2014) . ع. تنكيـن المحتوى ليتم إنتاجـه في أماكن

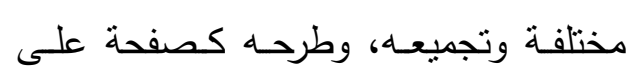
شبكة الإنترنت في متتاول المشاركين.

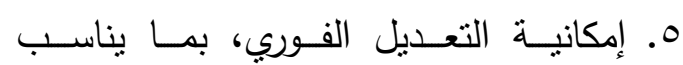
المشاركين.

7. التخذية الرتدة، وتبادل الأفكار ، والتشاركية، والاتصال المستمر .

(Pappano, Laura, 4 / 11 / 2012) (Lewin, Tamar , 20 /2/ 2013)

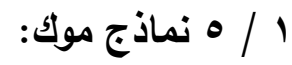

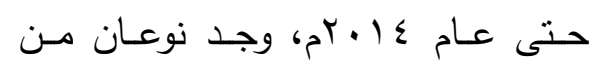

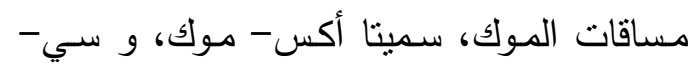

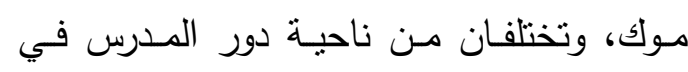

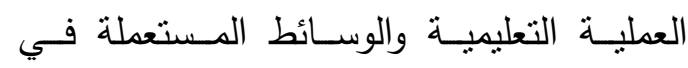
التواصل بين الددرسين والطلاب.

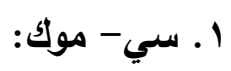


العدد الرابع والخمسـون - 7 •

هذه المساقات المتاحة عبر الإنترنت سيتم

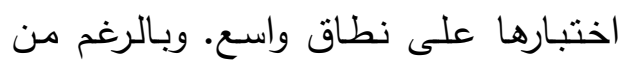

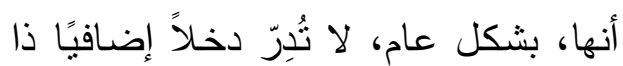

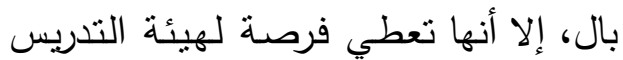
لتطوير طرق جديدة لتدريس العلوم، وتوصيلها إلى جمهور جديد، وتشجيع النقاشـات عبر الوسـائل المـتطورة . (Germain, Elizabeth St.6 / 11 / 2011)

r- مفصل وفقًا لخواص واهتمامات المتعلمين؛ حيث تتسم برامج موك بالمرونة والحداثة، وبالتالي فهي أكثر قدرة على استبعاب براب خواص المتعلمين وتناولها للموضوعات محل الاهتمام الخاص بهم، والقدرة علي إنتاج مساقات أكثر تخصيصًا. ع- القدرة على إضـافة تحديثات مستمرة؛ لتعكس التغيرات في التكنولوجيا، أو الرؤى

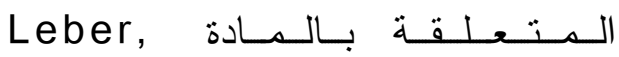
(15/3/2013) Jessica ه- مجموعات النقاش:حيث يمكن أن تشهر مناقثنات مكثفة، وحوارات محفِّة للأفكار حول القضية المثارة، أو المحاضرات، أو مورات حتى المحاضر • وتشجع مجموعات النقاش المتعلمين على تقييم تعليقات الزمـلاء، وهو ما يخلق في الغالب نوعاً من الدردشـة

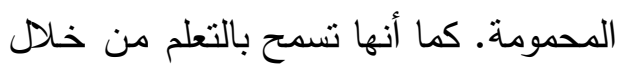
الأقران، فعلى سبيل المثال.. يقوم الطلاب
التقليديـة، لكنه مفتوح لعدد هائل من المتعلمين وأطلقـوا عليـهـ تـسمية "مـوك". وللتفرقـة بيـن

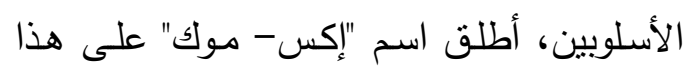
النوع الجديد من المساقات، رغم أن الجامعات الأكاديميـة رفضت هذه التسمية، واعتبرت أن نموذجها هو الموك الأصلي دون إضافات. وفي نموذج "الإكس- موك"، هناك دور رئيس لهيئة

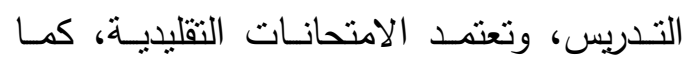
يفرض منصة إطلاق مغلقة، تعتمد على واجهة تطبيق محددة مثل كورسيرا أو يوداسيتي.

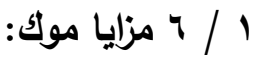

تتمنتل أهم مزايا المساقات المفتوحة واسعة النطاق عبر الإنترنت (MOOCs) فيما يلي: 1- لإقبال المتزايد من قبل المشاركين؛ حيث إنب يمكن أن يصل عدد المشاركين في برنامج دراسي واحد إلى ما يزيد عن مائة وخمسين ألفًا، ومن ثم فإنها تخدم جمهورًا أوسع وأكثر إنى تتوعًا من أي نوع آخر من أنواع التعليم عن إنها

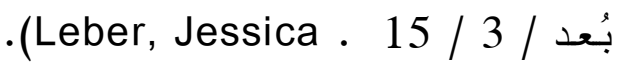
r- قد يشعر عضو هيئة التدريس بِيقِلَ التحدي المتمنل في جعل سلسلة المحاضرات في أحد الموضوعات الثائعة أقصر ، وأكثر

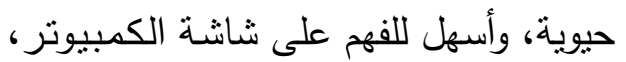
لكن مصممي تلاك المحاضرات الإكترونية المتمرسين يقولون إن تلك المهمة تستحق لئق بجدارة ما يبذل فيها من مجهود، وذلك لأن 
للمقررات الجامعيـة المتاحـة عبر الإنترنت أن يمنح الأساتذة في بداية مشوارهم المهني شيئًا آخر : الشهرة. ويؤكد سان ليجيه (أحد

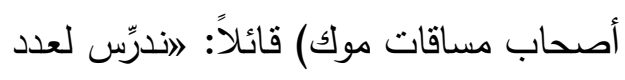
مـن الطـلاب في هذه الدورة، ربمـا أكبر

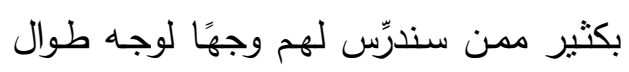

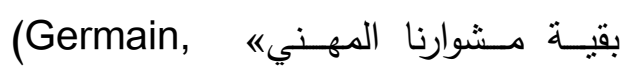
Elizabeth,. St. 6/11/2011) 9- مبدأ المجانيـة؛ فغالبَّا مـا تكون المساقات المتاحة عبر الإنترنت مجانية، ولها منهج

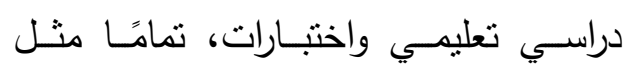
نظيراتها التي تدرس في الجامعات، ويمكن أن بُطلب من المتعلم مقابل مادي (رمزي)،

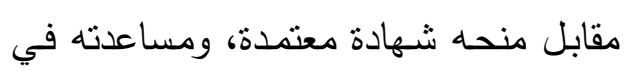
الحصول على فرصـة عمل، ولا يكون هذا

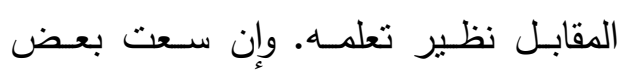
المنـصات خـلد الفـترة الأخـيرة لإلـزام المتعلمين بدفع رسم تسجيل عند التسجيل،

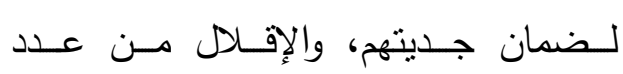
المتسربين منهم.

كما أضـاف أحد الباحثين المزايا التالية

لموك: (Mackness, Jenny, 2013) ا- مناسـبتها لأيــة مجموعـات مهمـا زادت

$$
\text { أعدادها. }
$$

r- إمكانية التعامل بعدد كبير من اللغات

(منل : الإنجليزية، والفرنسية ، والإيطالية، والألمانية، والإسبانية، والتركية، والعربية، ولئل
بمساعدة بعضهم البعض فيما يتعلق بالواجبات المنزلية، أو بمراجعة نتائج

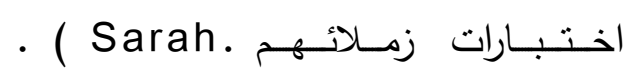

Kellogg,.2013) 7- التكامـل مـع نمط حيـاة المتعلمين: حيـث تتميز الدراسـة باستخدام موك بالمرونة التي تئي

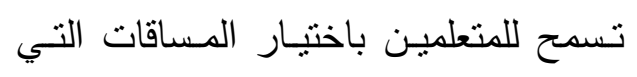
يرغبون في دراستها وتحديد عدد الساعات باتيات

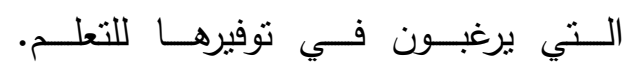
(Germain, Elizabeth,. St. 6/11/2011) - الخدمات الإككترونية الثاملة: تقدم منصات

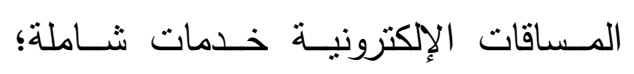
لمسـساعدة المحاضــرِين علـى تـصيم منـاهجهم، ومساعدة الطـلاب في تعليمهم وفي أدائهم الواجبات المنزلية. وبينما بعتقد

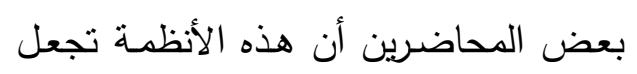

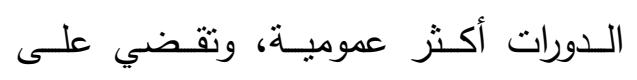

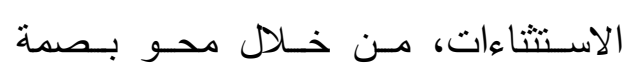

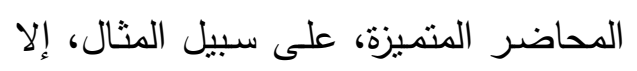

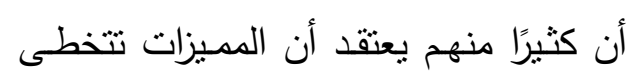

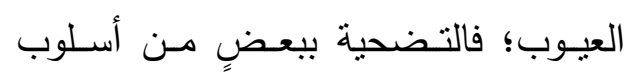
التدريس الثخصي يتيح لهم تبسيط عملية

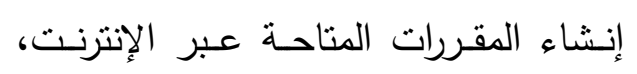
وكسب إضـافات مس خبراء التكنولوجيـا. Sarah (Kellogg, 2013) ^- الشهرة؛ فبإمكان القبول الجماهيري الواسع 
العدد الرابع والخمسـون - 7 •

التدريبيـة المتخصصسة في المجـال، والمخصصة للمحترفين، بشكل مجاني تقريبًا، مما يقلل من الأعباء الاقتصادية

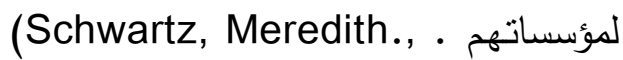
$10 / 5$ / 2013) r- التواصل الدولي بين المتعلمين من خلال المشاركة في المنتديات، مما يؤدي لمزيد من التلاقح الفكري، واستعراض التجارب،

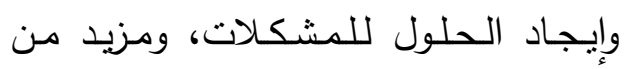
التعاون الدولي في المجال. ع- إفادة أخصائيي المكتبات، بما تحققه من صقل مهاراتهم بهدف الترقية، أو مساعدتهم لأداء عملهم بشكل أفضل، أو تدريب غير العاملين منهم للحصول على وظيفة، بما لادناء ينتج في النهاية نرقية في السيرة الذاتية دون تكلفة - ثقريبًا - أو تجشم عناء سفر. 0- تمكين المكتبيين من التحكم في جدول أعمالهم، فهم غير مجبرين على الذهاب

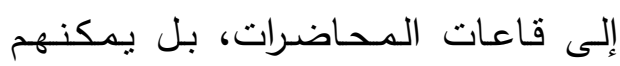
الاطلاع على المحاضرات في أي وقت شاعوا.

צ- التمكن من الحصول على شهادة معتمدة من كبرى الجامعات الدولية كهارفارد وبيل،

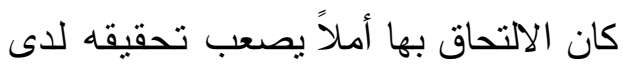
الكثيرين.

V- توثيـق الاتصـال بين هيئة التدريس والمتعلمين؛ لأن المتعلم يتصل بأستاذه من لن لـن

$$
\text { والعبرية...الخ). }
$$

r- عدم التزامنية: ويتيح ذلك مزيدًا من المرونة للمتعلمين في تحديد أوقات الدراسة واختيار المكان المالأم لذلك.

ع- القضاء على الحواجز الزمنية والجغرافية. 0- إمكانية الحصول على المساق في وقت أقصر ، مقارنة بصورته التقليدية. 7- عـدم وجـود حـواجز أمسام الـتحساق المتعلمين. V- V- Vسين مهارات التعلم مدى ود الحياة. - 1مط تعليم غير رسمي، ومن ثم لا يخضع للبيروقراطية، والقوانين واللوائح التقليدية. 9- تعزيز بيئة التعلم بالمشاركة.

وتمتاز برامج موك في مجال المكتبات

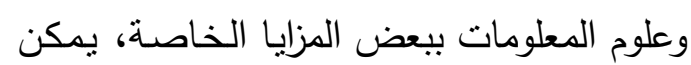
الوقوف على بعضها فيما يلي: 1- إسهامه في تحقيق التكامل بين المجالين النظري والميداني، في ظل وجود عدد كبير

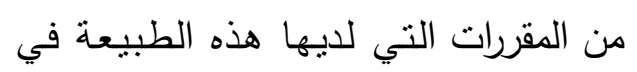
المجال، خاصة مقررات الحاسب، مثل: قواعد البيانات، ونظم المعلومات، وتطبيقات

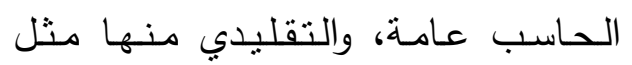

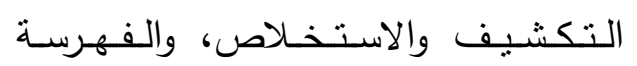
والتصنيف.(Barron, 2013) ץ- الاقتصاد في نفقات الدورات التدريبية؛ حيث يمكن للعاملين في أحدى مؤسسـات المعلومات التسجيل معًا في إحدى الدورات 
من يحصلون على شهاداتها من المسجلين

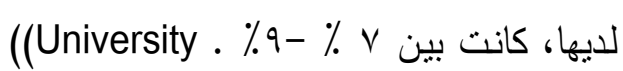
؛ of Pennsylvania. 7 / 11 /2013) حيث كان معظم الطـلاب المسجلين ينوون استكشاف الموضـوع، وليس إكمال الدورة،

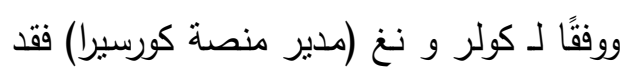

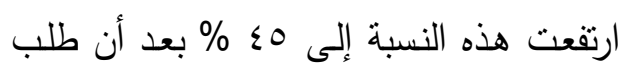

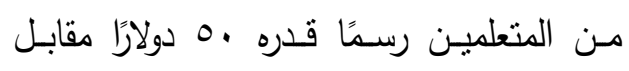
التسجيل فـي المساق، ضــــاناً للجديـة. (Kolowich, Steve ,8 April 2013) r- اعتقـاد البعض بيُعد مـوك عـن التجربـة

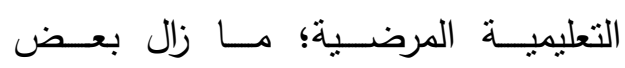
المتشككين في برامج موك في ريب أيضًا

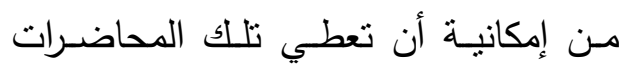

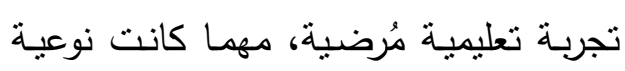

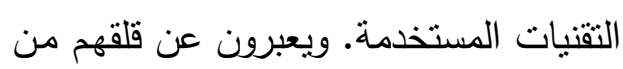

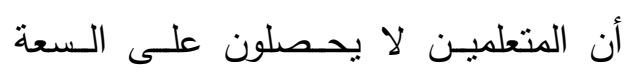

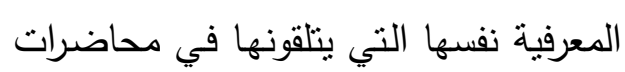

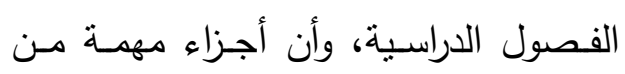
المحتوى الدراسي قد لا يتم التطرق إليها. (Leber, Jessica . 15 / 3 / 2013) ومثل هذه المخاوف يمكن التخفيف

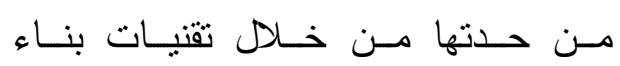
المجتمعـات الـتي تسمح للطـلاب بينـاء صـات ببعضهم البعض، وبمدرسيهمه.

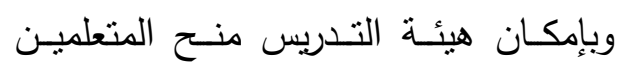

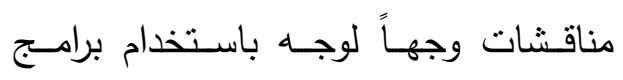

خلا الإنترنت، و يتلقى الأستاذ الرسالة في

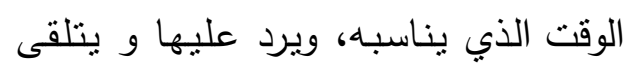
المتعلم الرد في الوقت الذي يناسبه، ويناقثه لونه

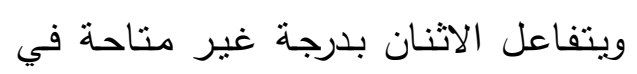
النظام التعليمي التقليدي. ^- إنـه يتناسـب مـع النقدم العلىي الـسريع

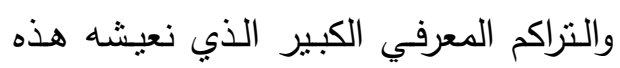
الأيام في تخصص المكتبات والمعلومات؛

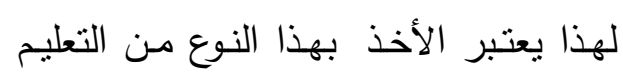

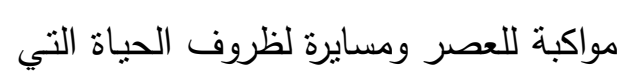

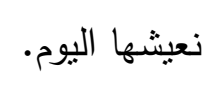

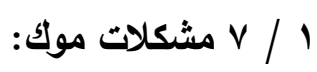

تتمثل أهم مشكلات المساقات المفتوحة واسعة مئل النطاق عبر الإنترنت (MOOCs) فيما يلي:

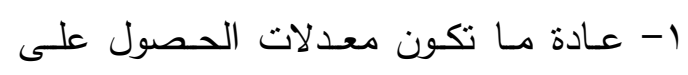

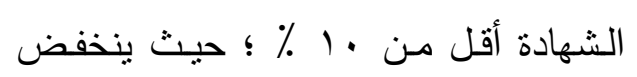
عدد المشاركين ابتداء من الأسبوع الأول . وعلى سبيل المثال ففي مساق:" الكهرباء

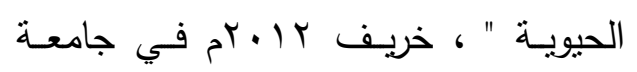

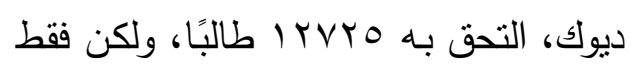

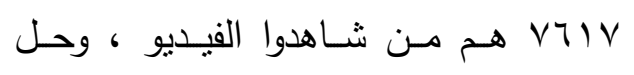

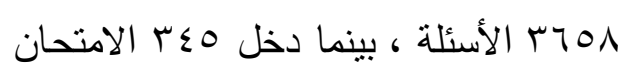

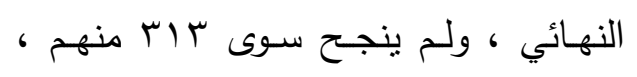
وكـانوا هـم مـن حصل على ولجى الـشهادة. (Jordan, Katy, 23 / 4 /2013) (Catropa, Dayna,24 /2 / 2013) وتشير بيانات Coursera إلى أن نسبة 
العدد الرابع والخمسـون - 7 •

كله، حتى يتمكن كل طالب مـن الدراسـة بالمعدل الذي يناسبه، كما أن المحاضرات لئهن على 》اليوتيوب) أو غيره من مواقع التعلم عبر الإنترنت قد تبقى متاحة إلى الأبدا،

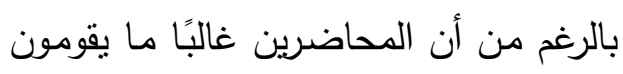
بمحو المواد القديمـة، وقد تفعل الجامعات نفسها ذللك. وعلى العكس.. يعطي كل من

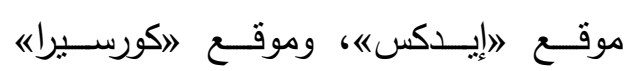

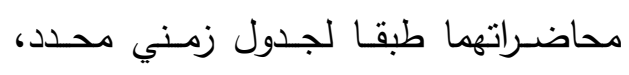

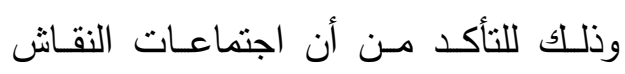

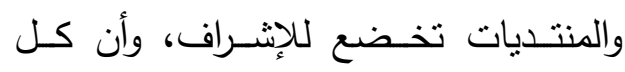
الطلاب يدرسون الأشياء نفسها في الوقت ذاته (Kellogg, Sarah. 2013) ؟- الجهد الكبير المبذول من قبل العاملين في المنـصات؛ حيـث إن التعـديلات الرئيسـة فئة الشاملة لمنـاهج التـدريس المفتوحـة، ومــا تتطلبه من إبداع تحتاج استثمارات ضخمة ومستمرة في العنصر البشري، سواء على إلى لـ المستوى التقني، أو اللغوي؛ فالترجمة الفعالة

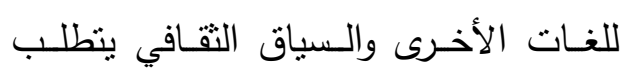
استثمارًا أكثر للمعرفة عند طاقم العاملين، وهذا واحد من أسباب أن اللغة الإنجليزيـة

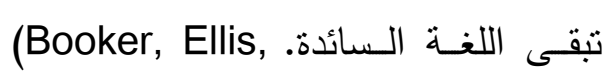

$$
30 \text { / } 1 \text { / 2013) }
$$

- ارتفاع تكلفة هذا النوع من التعليم خاصـة في بداية التأسيس وما تحتاجه هذه المرحلة مـن أجهزة متطوّرة في وسـائل الاتصال
اتصال عبر الإنترنت؛ كمـا أن بإمكانهم التفاعل مع المتعلمين عبر منتديات النقاش الدراسية. ب- اختلاف خلفيات المشاركين؛ فبعضهم قد يكون حاصـاًً على درجات علمية في هذا

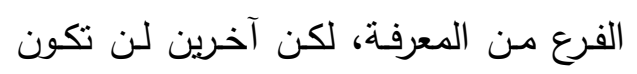

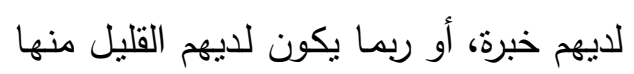
فقط. ومن ثم فإن على المحاضر أن يمتاز بالحرفيـة فـي إدارة المحاضــرة، ويقــول

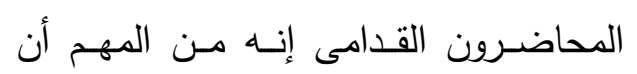
تعطي في بدايـة الدورة خلفيّةً معلوماتيـة توضـح المبـادئ والمعـارف الرئيسة للمـادة (Germain, Elizabeth St. 6/11/2011) ع- الاختلاف الكبير في البيئة التعليمية؛ وتتبع المسشكلة مـن عـدم وجـود محيط واقعـي ملموس، مع عدم قدرة الأستاذ على التجول في المكان. ومن ثم ينبغي تجنب الحكايات، والالتفافات اللفظية، التي قد تبدو منطقية في الفصول الدراسية، لكنها بالطبع تكون غير مناسبة في التدريس عبر الإنترنت. (.Kellogg, 2013) Sarah ه- اختـلاف المساقات الجامعيـة المتاحسة عبر الإنترنت عن التدريس في الجامعة؛ إذ إن الطلاب لا يتلقون بالضرورة المادة العلمية

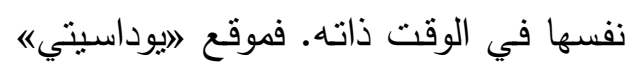

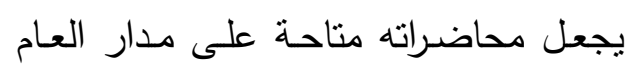


الأمريكية التي تفرض عقوبات على العراق وإيران والسودان وسوريا وكوبا، واضطرت لحجب خدماتها عن التابعين لتنك الدول؛ ومن ثم بمكن لهؤلاء الوصول للصفحة

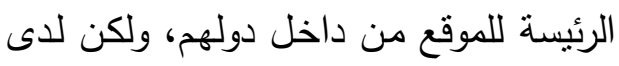
محاولـة تسجيل المستخدم بحسابه الذي دئي يمكنه من الوصول إلى المساقات التعليمية، تظهر لـه الرسـالة التاليـة: "يشير النظـام

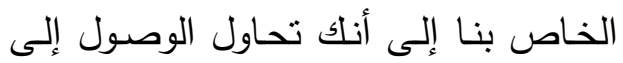

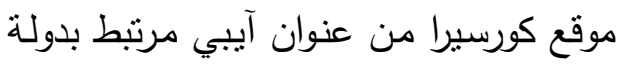
خاضعة حاليًا لعقوبات اقتصادية وتجاريـة أمريكية. وكي يتمكن كورسيرا من الامتثال

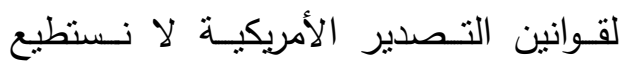
السماح بالوصول إلى هذا الموقع". ويجد الموقع نفسه في حرج شديد؛ إذ إنه ملزم بقرار المقاطعة الصادرة عن مكتب مراقبة الأصول الأجنبية التابعة للخارجية الأمريكية

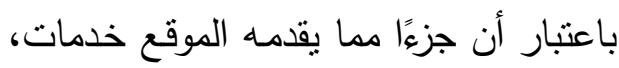
خاصة وأن فلسفة الموقع قائمة على إناحة التعليـم للجميـع داخلـل وخـارج الولايسات المتحدة، خصوصًا أولئك الذين تعوزهم

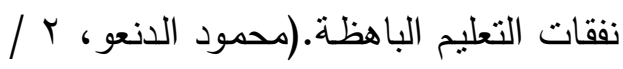

$$
\text { (r.) } \leqslant / 1
$$

ومهما يكن من أمر هذه المشكلات فإنها تتضاعل كثيرًا أمسام الميزات الاستثنائية لبراهـ هردج موك. 1 / 1 العالم العربي ومنصات موك:
الحديثة وتقتيات المعلومات، وكذللك تكلفة الصيانة الفنية، فهي تكلفة تكنولوجيا التعليم وما برتبط بها من تكلفة إعداد المادة العلمية وتصميمها وتكلفة الإرسـال عبر الأفمـار الصناعية وتكلفة أعضاء هيئة التدريس الإسيا

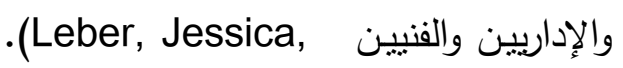
15/3/2015) ^- التدريس بأسلوب مـوك يحتاج من هيئة

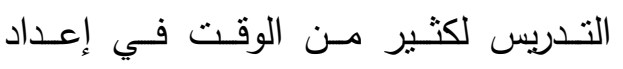
المساقات، والتوصيف الدقيق لها، والمواد

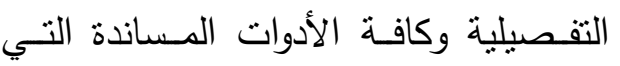

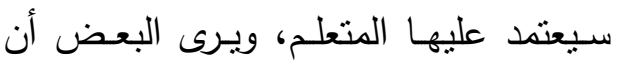
الوقت المطلوب لإعداد مساق موك يزيد بحوالي (74\%) من الوقت المطلوب لإعداد

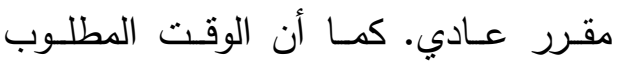

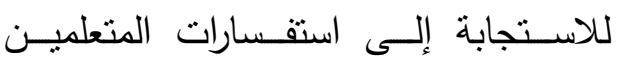

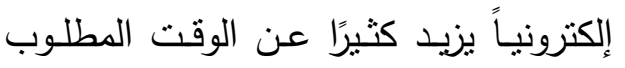

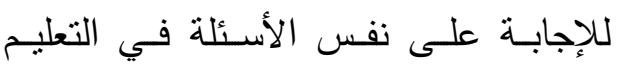

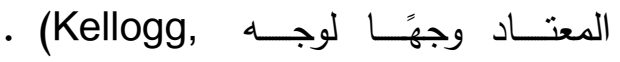
Sarah .2013) 9- الخلط بين العلم والسياسة؛ حيث تضطر

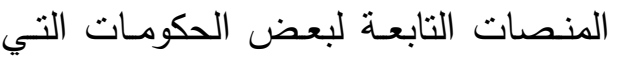
تفرض عقوبات على دول أخرى إلى تتفيذ التهات أوامر تلك الحكومات، بحجب خدماتها عن درل

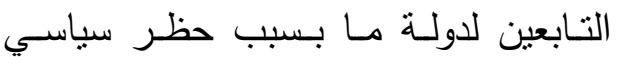
مفروض على هذه الدولـة، وعلى سبيل

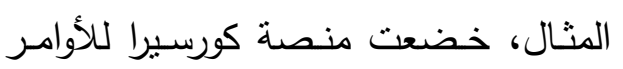


مجموعة من الدورات في مختلف فروع العلم. لا تعتمد فلسفة الأكاديمية بشكل كبير على البحث

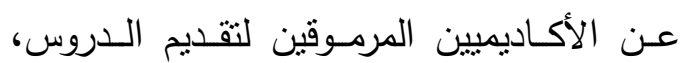
ولكنها تهتم أكثر بمن لديه القدرة على تبسيط العلوم وتقديمها في شكل محبب وجذاب.

لـديها دورات مبسطة فـي مجـالات

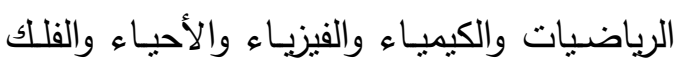

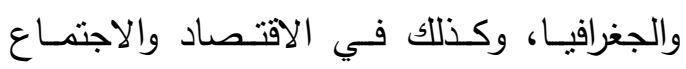

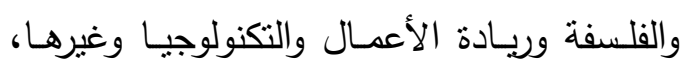

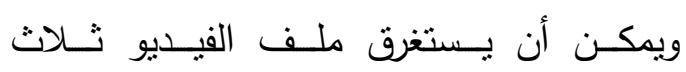
دقـائق.والمحتــوى التعليمسي علـى "التحريـر أكاديميي" هو ما يتم دراسته من الصف الثالث

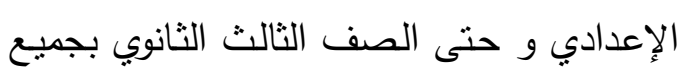
تخصـصاته، أمـا عـن المسشاركين الـذين تتـ مخـاطبتهم وتوجيـه الـدروس لهم، فهم طـلاب

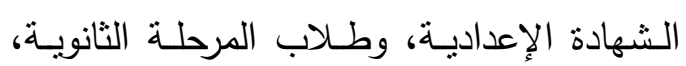
وطلاب الفرقة الأولى بالجامعة، وكذلك كل من يرغب في معرفة خبايا شئ جديد عليه أو يتذكر الأساس العلمي لشئ سبق و أن درسه .

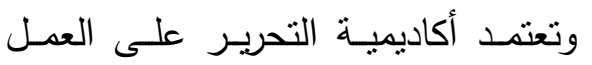
التطوعي، وقامـت بطرح رسـالة على موقعها

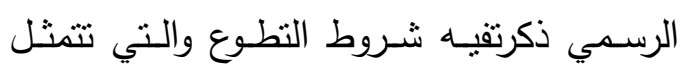
في :وجوب توافر الرغبـة الصادقة لدى المنطوع

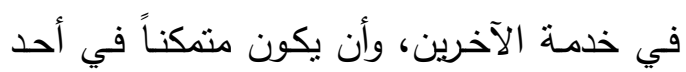

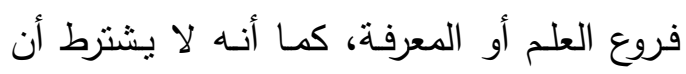

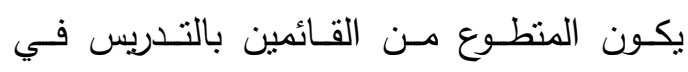
المدارس، بالإضـافة لتمكين طلبة الجامعة من لـن بـن
تعتبر اللغـة المشكلة الأبـرز لعـدد ممـن يريدون التعلم عبر MOOCs، خاصـة وأن معظم هذه المساقات يتم تقديمها باللغـة الإنجليزيـة، وقد

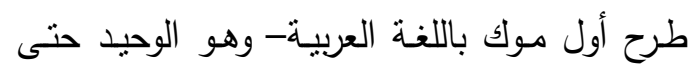
الآن - مـن قبـل جامعـة تيخيـون الإنـرائيلية Technion - Israel Institute of Technology

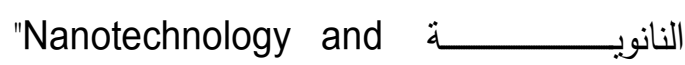
Nanosensors كورسـبرا، واسـتخرق تقديمسه · أسـابيع، ودرسـه البروفيسور حسام حايك. (حسام حايك، ع ( • rم). ورغم انتشار منصات MOOCs على

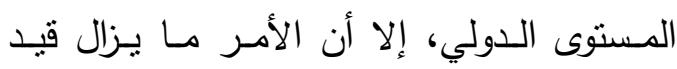

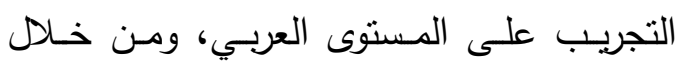

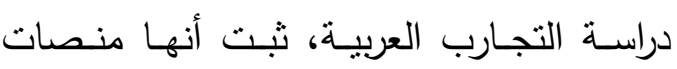

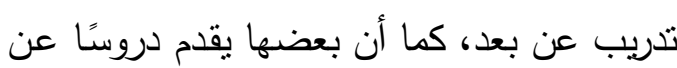

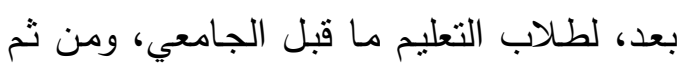
فلا توجد منصة موك عربية متخصصة في

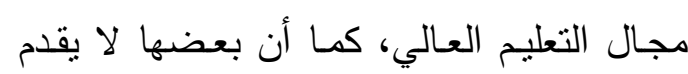

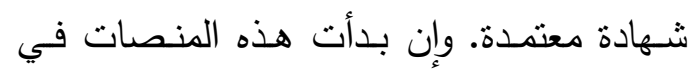
الظهور والانتشار خلال الفترة الأخيرة، وهي في لهي

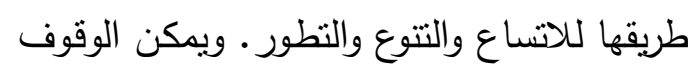
على أبرز هذه المنصات فيما يلي:

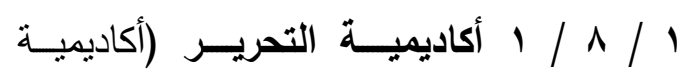

$$
\text { التحرير ، ع ا ب rم): }
$$

بوابة تعليمية غير هادفة للربح، تستهدف إعادة ثقديم المعرفة بطريقة شيقة ومبسطة عبر 
تكون مدرسـاً ناجحاً؟، وتتبـح المنصة - مسن خلال منتداها - إمكانية طرح أسئلة، أو تصفح

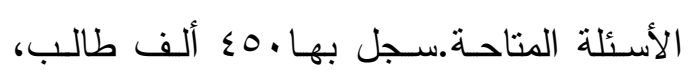

$$
\text { وتمت · r مليون مشاهدة. }
$$

/ / / أكاديمية ملتقى الدارين: 1

أحدى الجمعيـات الخيريـة التابعـة لـوزارة

الشئون الاجتماعية المصرية، يقع مقرها بمدينة الإسكندرية، قائمة على الجهود التطوعية، بدأت الفكرة كمشروع تعليمي هدفه توفير التعليم لجميع الإنيع لهنه النـاطقين باللغـة العربيـة، في مختلف المراحل وفي شتى العلوم.الفكرة عبارة عن موقع إلكتروني خيري وغسير ربحس، يهدف إلسى المسساعدة

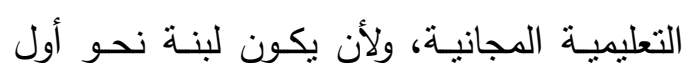
جامعة عالمية مجانية ذات طابع إسـامي. يتيح

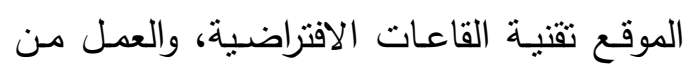

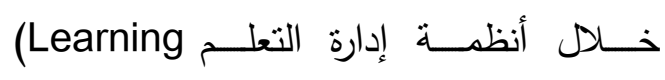
(أكاديميــــــ Management Systems). ملتقى الدارين، عن الأكاديمية، ع ( • بم).

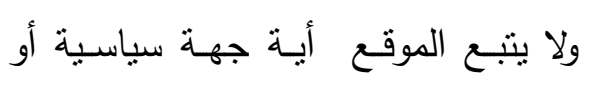

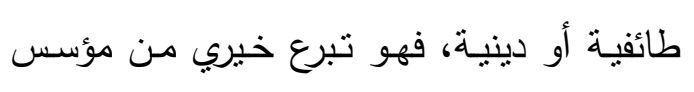

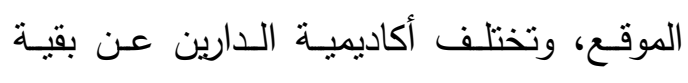
المنصات في أنها ما تزال تقدم دوراتها بالطريقة

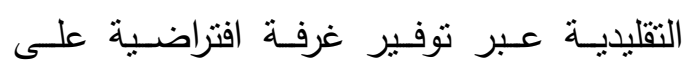
الإنترنت للمحاضـر والطلاب للتواصل مباشـةًة وليس دن خلال تسجيل المواد كما في الطريقة المتداولـة الآن، وتخطط المنصة لرفع الدورات
المساعدة إذا كانت دراستهم في الجامعـة قد ساعدتهم على فهم أكثر لما سبق دراسته في الثانوي، وكذلك إذا كان منمكنًا، ويمكنه شرح أحد الموضوعات بشكل احترافي من الواقع، نتيجة احتكاكه بمجال العمل مباشرة .

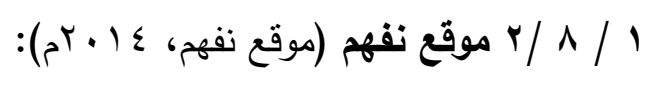

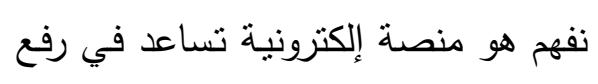
قدرة الطلاب على استيعاب الدروس ومراجعتها من خلال توفير طرق وأساليب تعليمية تفاعلية. مبادرة نفهم هي خدمة تعليمية إلكترونية مبتكرة على الإنترنت تقدم شرحًا مبسطًا لمناهج التعليم المدرسي في مصر وسوريا والسعودية والجزائر عن طريق فيديوهات مدتها من 0- •ب دقيقة.

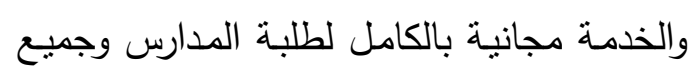
المستفيدين منها. ويحتوي الموقع على أكثر من سب ألف منف ملف فيديو في تبسيط المناهج الدراسية العربية، وإلى جانب المناهج المدرسية، يأتي قسم "تعليم حر" ليقدم عددًا من المقررات التعليميـة العامـة غـير المرتبطــة بـالتعليم الرســي في صـي صورة أساسيات ومبادئ مجالات مختلفة لإثراء وتتمية

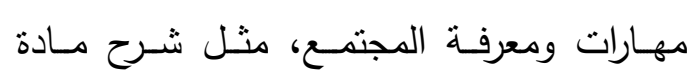

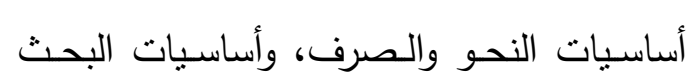

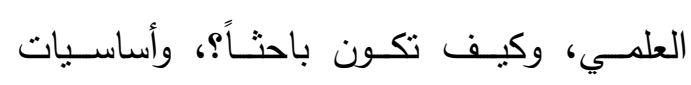

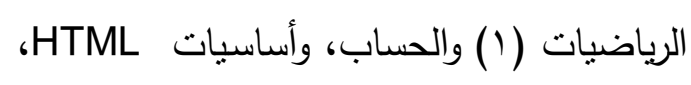
وشرح باللغة العربية، وأساسيات الشرح، وكيف 
العدد الرابع والخمسـون - 7 •

\ / / / ـ وقف أون لايـن(وقف أون لايـن، $:(5,+) \varepsilon$

موقع عربـي للتدريب عـن بعد وتلقي

الـدروس مجانَا، يهتم بشكل أكبر بمجـالات التقنية والبرمجة والإدارة، ويحتوبي على عشرات الدورات في لغات البرمجـة والتسويق والثبكات والعلـوم الإداريـة وغيرهـا، متـاح على الـثبكة الدولية على مدار الساعة، ويتكون طاقم وقف أون لاين من إدارة، ومشرفين، ومدربين وتقنيين من بلدان عربية متعددة. / / 9 / المكتبات وموك:

أحدثت البيئة الافتراضية - كأحد أبرز

إفرازات عصر المعرفة والتكنولوجيا والاتصالات - كثيرًا من التغيرات في جميع مناحي الحياة.

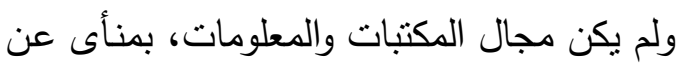

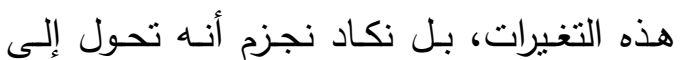
مسرح لتلقي المعرفة، ونموها، وتحليلها، والربط بينها وبين تطبيقاتها المختلفة، تحت مظلة الحياة الثانية Second Life، والتي لم تعد حكرًا على المستخدمين النمطيين، كما أنها ليست مجرد تقتيـة أو حاجـة تشبع فضول مدمني الشبكات الاجتماعيـة. ومن هنا فقد دخلت برامج موك عالم المكتبات والمعلومات، كما دخلت إلى غيره

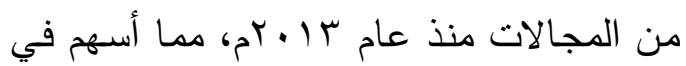
تمكينهـه مـن مواكبـة العـصر، والإفـادة مـن الإمكانـات الاستتثنائية التي تتمتـع بهـا برامـج موك. ونستعرض فيما يلي العلاقـة بين مجال
والمحاضـرات على الإنترنتـ. (أكاديميـة ملتقى الدارين، عن الأكاديمية، ـ ( ب (ب).

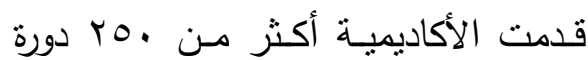

تدريبيـة مجانيـة في مجـالات متعـدة، وتوفر إمكانية الاطلاع على محتويات هذه الدورات من خـلال قناتهـا على موقع يوتيـوب. (أكاديميـة ملتقى الدارين،الوسائل المتاحة، ع ( • بم). ويتميز الموقع بما يلي: (أكاديمية ملتقى

$$
\text { الدارين، الوسائل المتاحة، ع ( • rم): }
$$
1- حضور المحاضـرات الحيـة على الهـواء مباشرة بالصوت والصورة من خلال الموقع. r- تواصـل الدارسـين مـع المحاضـر بوسـائل التواصل المختلفة. r- التسجيل والحضور مجاناً من خلا الموقع. ع - إمكانية تحميل المحاضرات المسجلة. 0- خدمة التقييم والاختبارات للدارسين. 1- خدمة إبداء الرأي في المادة المقدمة والنقاط التي يجب أن يراعيهـا المحاضـر لزيـادة النفع - يتيح الموقع تبادل الخبرات من كل أنحاء

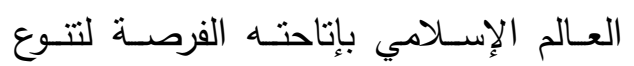
الدارسين والهحاضرين. 人- إتاحته لخدمة تمتد بعد انتهاء مدة كل دورة لطرح التساؤلات التي قد تواجـه الدارسبن أثناء تطبيقهم لما تم دراسته. 9- يصدر الموقع إفادات بنسبة حضور الطالب

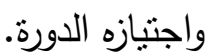


سـلوكيات مستستكي المعلومـات فـي البيئـة الرقميـة، واتجاهـاتهم وتوقعـاتهم للتعلــم عبـر

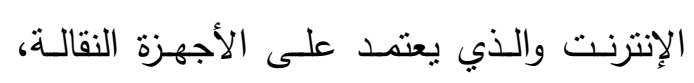

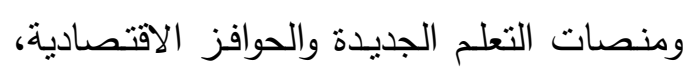

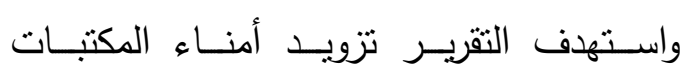
بالمعلومات المهمة حول الاتجاهات والمحركات التي تعيد تشكيل التعليم، والفرص والتحديات التي يُحدثها منل هذا التحول في بيئة المكتبات. انتهى التقربر إلى عدد من الحقائق والتوقعات المتنلــة فيمـا يلـي: ( / OCLC, 6 / . $(2014$

1- يوحي التقرير بأن الوزن التراكمي لتغيير عـادات المستهلك، وتمكين الثقنيات مثل بنل MOOCs والهواتف الذكية، وارتفاع تكاليف ونئن التعليم الجامعي، سبعيد تثبيت التوقعات السابقة وسيحدث تغييرات دائمة في التعليم

$$
\text { والتعلم مدى الحياة. }
$$

r- يمثل هذا التقرير محطة نوعية في سلسلة

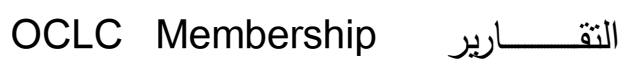
Reports الاتجاهات الناشئة التي تؤثز على المكتبات

$$
\text { وأخصائي المكتبات. }
$$

r- ينظر تقرير نقطة تحول إلى آراء المتعلمين على الإنترنت ومخـاوفهم الخاصـة بتكلفـة التعليم العـالي، وتجـاربهم مـع التعلم عبر

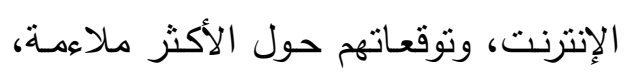
وأدوارهم في المستقبل في ظل نماذج التعليم
المكتبات والمعلومات وبرامج موك المعاصرة.

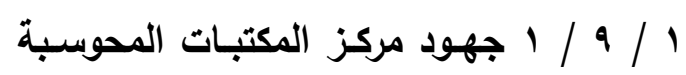
على الخط المباشر OCLC: OCLC

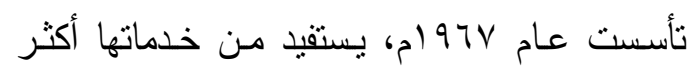
من ع V ألف مكتبة، تنتشر في •V V دولة، بمكنه

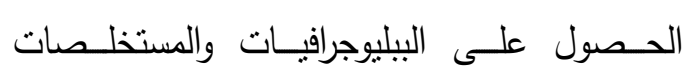
والنصوص الكاملة. والمركز عبارة عن تعاون بين المكتبات والأرشيفات والمعاهد العلمية الأخرى التي تئي تشارك في المعلومات عن المقتيات الموجودة في

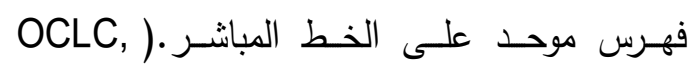
( 2014 ويقوم أعضاء OCLC بإنتاج وصسيانة الفهرس العالمي للمكتبات.World Cat، والذي يعد أكبر قاعدة بيانات في العالم على الإنترنت،

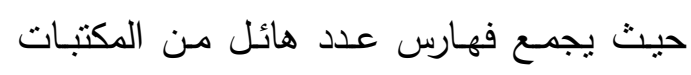
حول العالم. (OCLC, 2014) ومن أهداف OCLC، تخفيض تكاليف

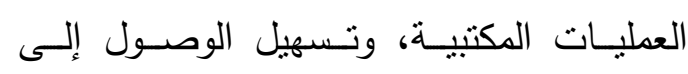
المعلومات العلمية والمعرفة في العالم. ( OCLC, .) 2014 وقد أدت جهود فرق البحوث التسويقية

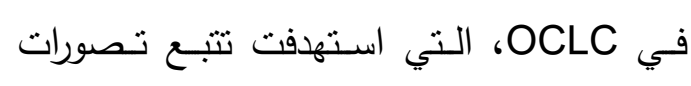
المستهلكين للمعلومـات لأكثر مـن عقد مـن الزمـان إلى الخروج بتقرير بعنوان: "في نقطـة

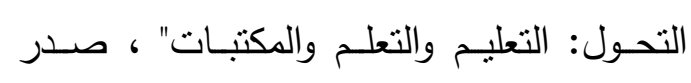
في هب يونيو عـ ا •rم. وقد استكشف التقرير 
العدد الرابع والخمسـون - 7 •

ج- يوفر التقريـر نقطـة تحول بيانـات خاصــة بمواقف المستهلكين وتصوراتهم حول التعلم،

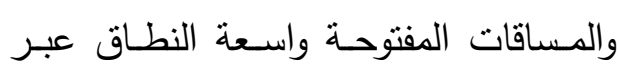
الإنترنت. كما يتضمن أيضًا بيانات حول توقعات المتعلمين لطبيعة مدى انخراطهم في الحرم الجـامعي واستخدامهم للمكتبـات سواء في داخل المكتبة أو عبر الإنترنت.

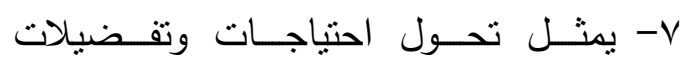
المستهلكين، فرصـة جديدة للمكتبات لتقديم كل الخدمات وتوفير سبل الراحة التي من شـأنها أن تزبـد مـن تأثنير وتعظيم أهميتها للمتعلمين عبر الإنترنت. ويتكون التقريـر مـن ستة فصول على لإنرى النحو التالي:

الفصل الأول: يقدم بيانـات حول التقدم

الذي أحرزه التعلم عبر الإنترنت؛ حيث يتسارع اعتماد مستهلكي المعلومات للتعلم عبر الإنترنت للحـصول علـى الــرجات العلميـة، وتطويـر مهارات العمل، وتحقيق التميز، والإثراء الذاتي. وقد شاركOCLC في هذا الفصل بوضع خبراته الخاصـة بنماذج التعلم عبر الإنترنت، بما في ذلك MOOCs، جنبًا إلى جنب مع انطباعات

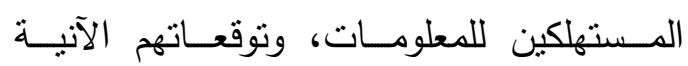
والمستقبلية الخاصة بالتعليم عبر الإنترنت.

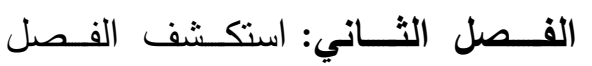
الاتجاهـات إزاء التعليم الجـامعي. وقد شــارك OCLC

\section{الجديدة.}

Cathy De "ترى السيدة "كاثي دي روزا" Rosa ، نائب رئيس OCLC للأمريكيتين والمساهم الرئيسي في تقريـر OCLC Membership على النماذج التقليديـة للتعلم. وقد عبرت عن ذلك قائلة: "نحن نرى دلائل هذا في نتائج الأبحاث التي نجريها، ونلمس نقاط التحـول فـي طريقـة تفكير المستنهكين ورغبتهم في إدارة تعلمهم. فالطلاب وأولياء الأمسور حريصون على مزيد من الراحسة

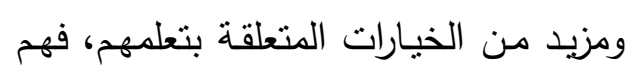

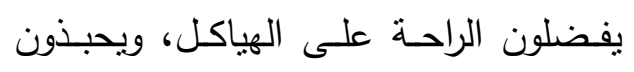
الخدمة الذاتية على الخيارات المحددة سلفًا، لماتهات وقد استطاع متعلمون من جميع الأعمار إحراز كثير من النجاحات من خلال التعلم

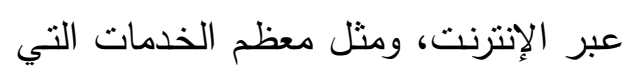

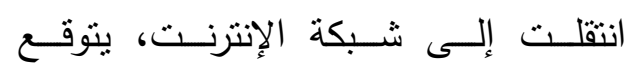
المستنهكون مـن هـذه الخدمات الجديدة مواصلة التحسن في نوعيتها والزيادة في هي شعبيتها" - مواصله 0- التغيرات في التعليم والتعلم عبر الإنترنت لها مقتضياتها، كما لها الفرص التي توفرها للمكتبـات، فنفس القوى الرقميـة التي تعيد تشكيل التعليم سوف تعيد تشكيل توقعات

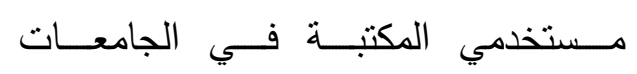
والمجتمعات. 
الملتحقين في برامج الدراسة عبر الإنترنت.

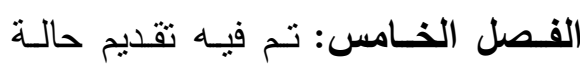

دراسية حول تأثير MOOCs، وكيـف يتم

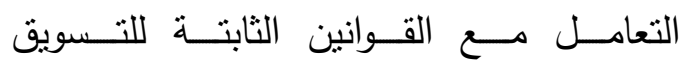
"immutable laws of marketing" Al "النسويق الناجح الني وضعتها "آل ريز

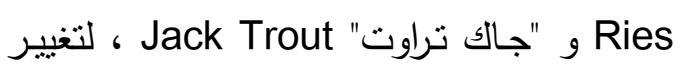
تصورات المستخدمين حول التعليم.

الفـصل السادس: لخص هذا الفصل

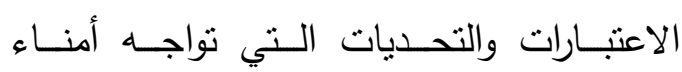

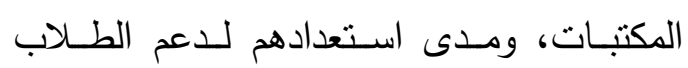
الملتحقين في التعليم عبر الإنترنت.

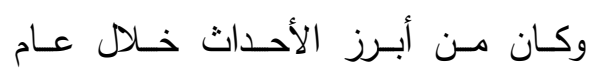

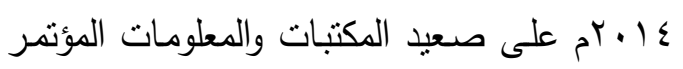
الدولي الذي عقده OCLC بالنعاون مـع الجمعية

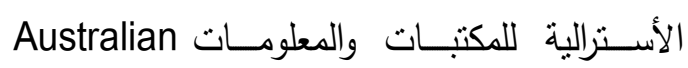
Library and Information, Association ALIA Council of Australian University Librarians, CAUL

The State Library of Queensland

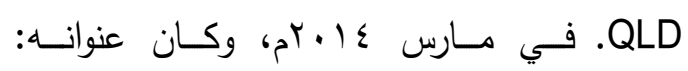
الككتبـات ومـوك والتعليم على الخط المباثـر Libraries, MOOCs and online learning

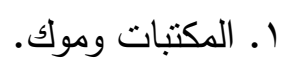
r. قـضايا متششابكة (المجموعـات، وحقـوق
الخاصـة بروئيـة المستهولكين للمعلومـات حول

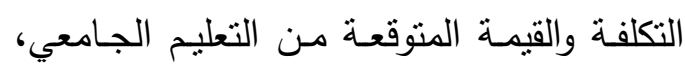
مؤكدًا على أن المتعلمين بمتلكون نظرة ثاقبـة

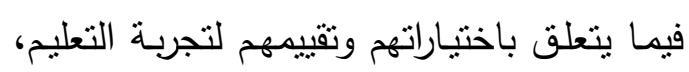

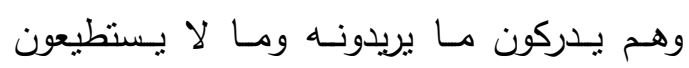
تحمله. الفصل الثالث: يعاود الفصل الخوض في

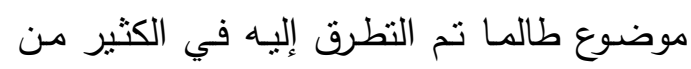

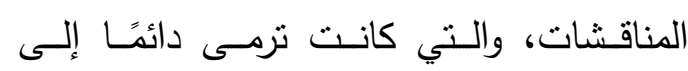

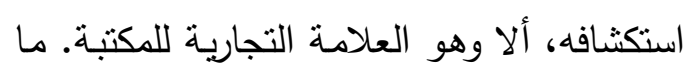

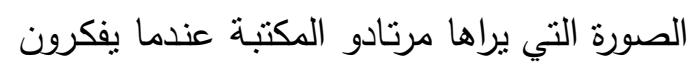

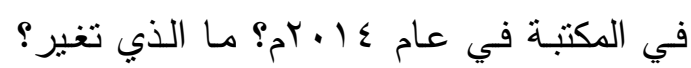

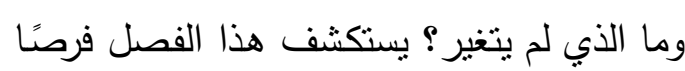

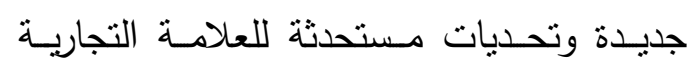
للمكتبـة في ظلـ تبنى مستهلكي المعلومـات مهارات واتجاهات جديدة للتعلم عبر الإنترنت. الفـصل الرابـع: يستكشف دور المكتبـة داخل الحرم الجامعي. باستخدام تقنية الخرائط

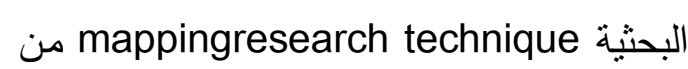
خـلال رسم خارطـة لنقافـة الطلبـة، والكوادر الأكاديميـة، والعاملين في الكليات، والخريجين من أجل فهم أفضل لاتجاهاتهم حول تجربـة

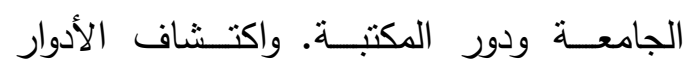
الاستثائية وغير الاستثائية التي تلعبها مكتبات ودات الاندات الجامعات في تشكيل خبراتهم التعليمية بشكل عام. كما تم في هذا الفصل استكثاف الخبرات الجديدة التي تضيفها المكنبات الجامعية للطلاب 
العدد الرابع والخمسـون - 7 •

بمساقات مـوك، أو برامج التعلم عن

بعد.

- يمكن استغلال نظم التعلم عن بعد لأداء

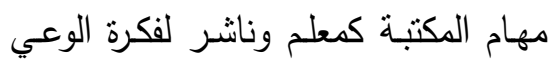

$$
\text { المعلوماتي. }
$$

وقد أسـندت الإفـلا خـلال عـام ع ا • بم

إلى عدد من الخبراء، مهمة العمل على بحث البيئة المتغيرة التي تحيط بنا وتحديد الاتجاهات التي ستؤثز على إناحة المعلومات في السنوات القادمة. وقد أدت هذه الجهود إلى الخروج بتقرير إفلا حول الاتجاهات IFLA Trend Report التي رأت أنه سوف يساعد المكتبات ومؤسسات

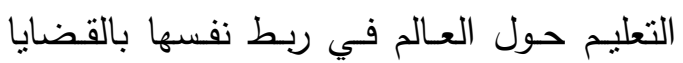
الجديدة وتقديم أفضل خدمات ممكنة للمستخدم. وقد ركز التقرير على حجم المعلومات التي يتم إنتاجها عبر الإنترنت وسرعة إنتاجها.

وقد حدد التقرير خمسة اتجاهات تشكل

مجتمــع المعلومــات، تمنلــت فـي: التعليــ Education Civic شاركة المدني. والمـ

Transfo والتحول التكنولوجي Engagement

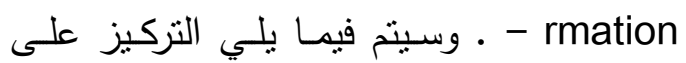
الاتجاه الثاني، وذلك فيما يلي:

الاتجـاه الثاني: التعلم الإككتروني عبر شبكة الإنترنت سيجعل من عملية التعلم أكثر الإنب ديمقراطية وتتوعًا. (IFLA., 2014). أكد التقرير أن التوسع العالمي السريع في موارد التعليم عبر الإنترنت سيجعل فرص التعلم
المؤلــف والمعلومــات، ومحــو الأميــة المعلوماتيـة، والوعـي المعلومـاتي، وأسـاليب الاقتباس والبحوث و مهارات الموظفين) r. كيف يمكن أن تدعم المكتبـات الأكاديميـة

$$
\text { التعلم عبر الإنترنت؟ }
$$

ع. كيـف يمكـن للمكتبـات الأخـرى (العامـة،

والمتخصـصة، والوطنيـة، والمدرسـية) أن

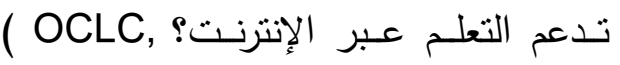

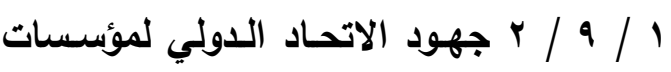
المكتبات والمطلومات IFLA المتود المات

يعــــ الاتحــاد الــدولي لمؤســسات المكتبات IFLA منظمـة غير حكومية مستقلة، ويعتبر أهم منظمة دولية تمثل مصالح المكتبات

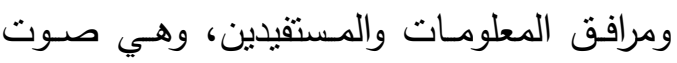

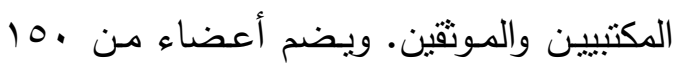

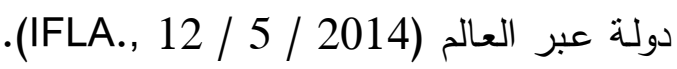

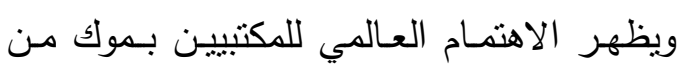
خلال إفراد الـ IFLA محورًا كاملاً في مؤتمره المنعقد في مايو، بحضور حوالي ثلاثة آلاف هوند

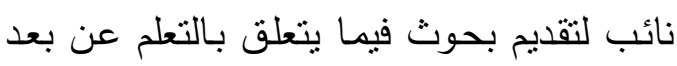

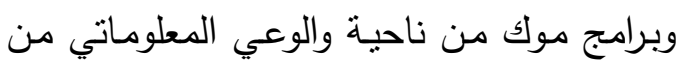
ناحية أخرى (IFLA, 2012). وقد انتهى المؤتمر في هذا المحور إلى ما يلي: - يعد الوعي المعلوماتي عنصرًا فاعلاً في كافة مقررات التعلم عن بعد؛ حيث ينبغي أن بتمتع المتعلمون بدرجة من من فئن

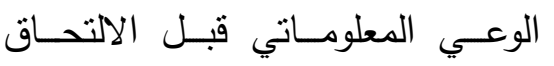


0- سـهولة الحصول على طرق تحديد أماكن

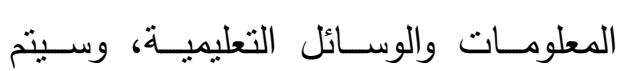
التركيز في المستقبل بشكل أكبر على ولى

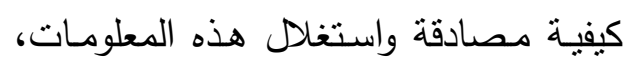

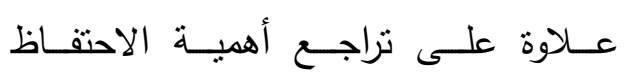
بالمعلومات.

ج- رغـم مـا تواجهـه الطـرق التقليديـة للتعلُم والمدفوعة بالتعليم عبر الإنترنت من بعض رغ

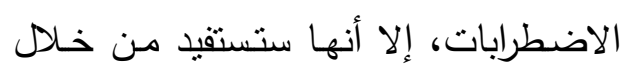
تخفيض التكاليف وزيـادة فرص الحصول الحصن على فرص التعلم على نطاق أوسع. - V تشكيل سوق التعليم في المستقبل بفعل تأثنر فير شـبكات تقودهـا شـركات الأعمـال مثنل

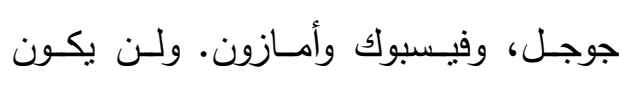

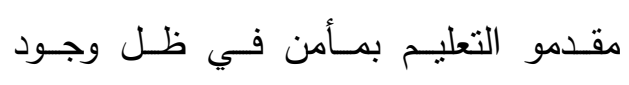
المنصات الجديدة مثل كورسيرا و إيدكس والتي توفر مجموعة واسعة من المحتوى.

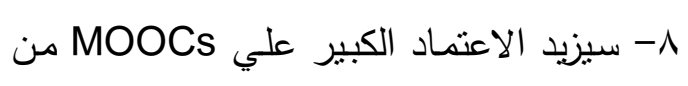
القيمة المضافة للوسطاء الذين يقدمون منبرًا للتعليم وشبكات التوجيـه والدراسـة التعاونيـة والتعاون والدعم غير الرسمي، وينطبق هذا التغيير علي التعلم عبر الإنترنت أو وجهًا لوجه.

ا 9 / / / تجربـة مكتبـات جامعة بنسلفانيا

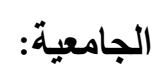

تعد جامعـة بنسلفانيا رابع أقدم مؤسسة للتعليم العالي في الولايات المتحدة، تأسست في
أكثر وفرة، وأرخص ثمنًا، وأكثر يسرًا. وسيحظى

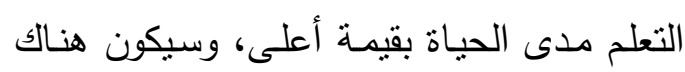
مزيد من التقدير للتعلم الرسمي وغير الرسمي. التطورات المحتملة: ا- توافر مصادر التعليم المفتوحـة المصدر وتقنيات تدريس المساقات المفتوحة واسعة النطاق عبر الإنترنت (MOOCs)، وسيعمل هذا على إحداث تحولات في مشهد التعلم العالمي على مدى العقد المقبل.

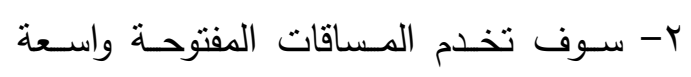
النطاق عبر الإنترنت مزيدًا من الدارسين

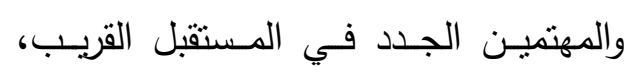
والذي من المتوقع أن يفوق عددهم العدد العدي

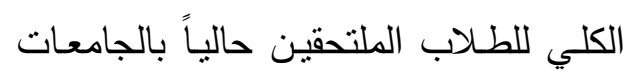
في مختلف أنحاء العالم. ب- أصبحت الفرص الرقمية للتعلم مدى الحياة متطلبًا ضروريًا على نحو منزايد في أكثر الاقتصاديات عولمـة. وسيكسب هذا مزيدًا

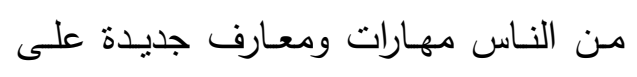
مدى حياتهم، في ظل بيئة تكنولوجية سريعة

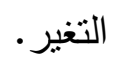
ع - سيعمل نوع جديد من الاستراتيجيات الأوسع

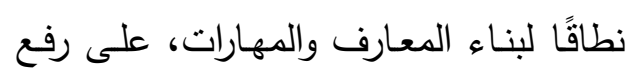
مستويات الاعتراف والنقدير لمسارات التعلم الرسـي وغير الرسـي. كمـا أن المهارات

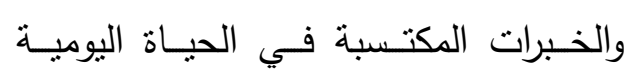
ستصبح أكثر وضوحًا وأعلى قيمة. 
العدد الرابع والخمسـون - 7 •

إتاحة دلبل استخدام المنصات، كما يمكنها مساعدة مرتـادي المكتبـة بالإجابـة مباشـرة

$$
\text { على استفساراتهم ذات الصلة. }
$$

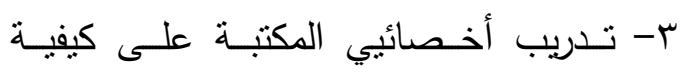

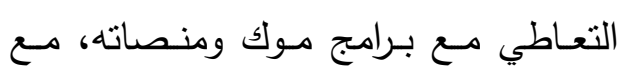
تشجيع أعضاء هيئة التدريس على إنتاج مساقات متخصصة في مجال المكتبـات اتمات والمعلومات.

ع - المشاركة في المنتديات الخاصـة بـ مـوك؛ حيث يمكن لأخصائيي المكتبة - من خله المنتديات المتخصصة -التفاعل مـع هيئة التـدربس والمتعلميـن فيمـا بتعلـق بتبـادل

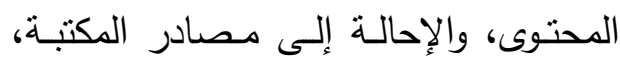
وتلعب المكتبة دورًا جيدًا فيما يتعلق بإفادة هيئة التدريس حول نشريعات حق المؤلف. / 9 / ـ برنامج الوعي المعلوماتي وموك: حددت اللجنة الرئاسية للوعي المعلوماتي Presidential Committee of Information Literacy المكتبات الأميركيـة: ALA في تقريرهـا النهائي لعام 919 ام "أن الثخص الواعي معلومانتًا هو القادر على إدراك متى يحتاج للمعلومات، ولديه القدرة على تحديد مكانها وتقييمها واستخدامها. فهو الثخص الذي تعلم كيف يتعلم Learned How to Learn يعرف كيف يصل إلى المعلومات ويستخدمها،

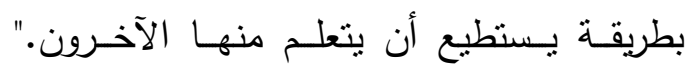

أربعينيات القرن الثامن عشر، وتعتبر الجامعة اليوم واحدة من أكبر جامعات القطاع الخاص في الولايـات المتحدة. وتتمتع الجامعـة بشهرة

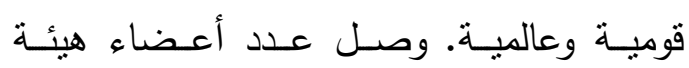

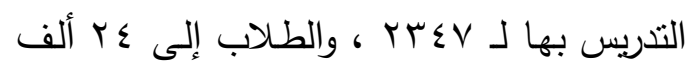
طالب، إضـافة إلى نحـو 11 ألفًا بالدراسـات

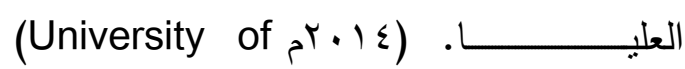
Pennsylvania

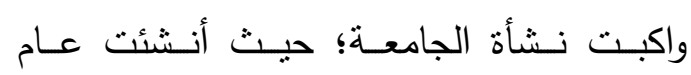
• V ام، ويصل عدد مصادرها إلى ستة ملايين.

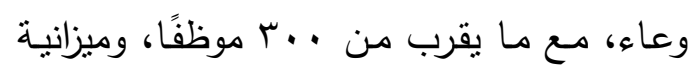

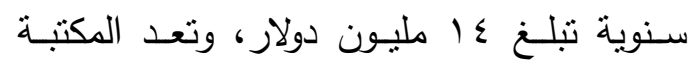
واحدة من أفضل المكتبات البحثية في أمريكا (Penn Libraries. About, الـــشمالية. (2014 وكانـت في طليعـة المكتبـات التي

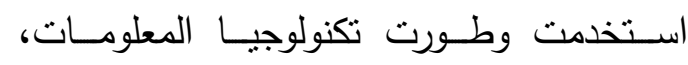
كالفهرسـة المحوسـبة، منـذ سـبعينيات القـرن

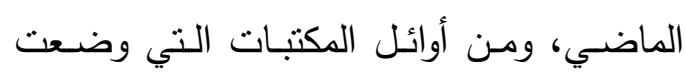

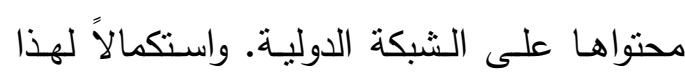

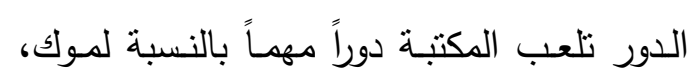
يتمثـلـل فيمسـا يلـي: . Penn Libraries) Services, 2014) 1- خدمـة مـوك؛ حيـث تتبـح المكتبـة روابط مباشرة بمنصات موك الكبرى، ومن أهمها

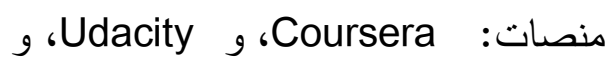

\section{.EDX}

r- تتمثل الميزة النسبية التي توفرها الخدمة في 
ع. الوعسي البحـثي، أو القدرة على فهـم

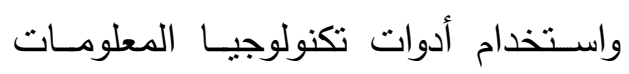
الأساسية ذات العلاقة بعمل الباحث.

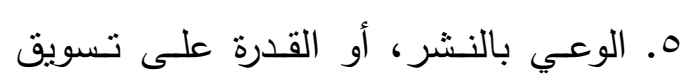

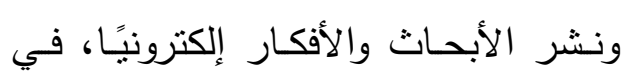
أشكال نصية أو ذات وسائط متعددة ... لتعريفها بالمجتمع الإلكتروني العلمي.

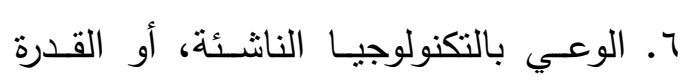
المستمرة على تبـني، وفهـم، وتقييـم

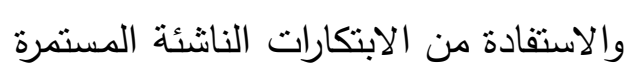
لتكنولوجيا المعلومات. V. الوعي النقدي، أو القدرة على التقييم الناقد

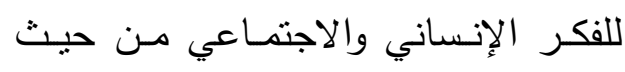
نقاط الضعف والقوة، وإمكاناته وحدوده

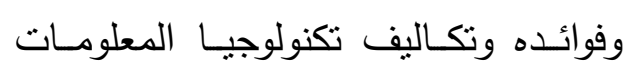
(Shapiro, Jeremy J. and Shelley K. Hughes (Mar/Apr

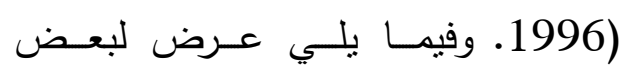

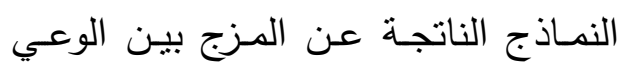
المعلوماتي وموك في المكتبات:

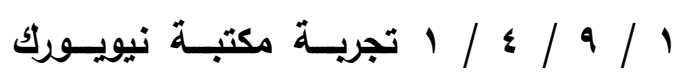
New York Public Library العامـة / :NYPL

تعد مكتبة نيويورك العامة أكبر مكتبة

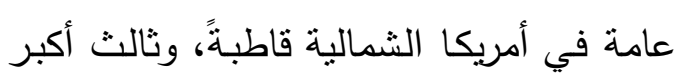

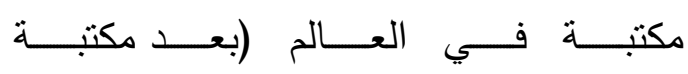

(ALA, 1989)

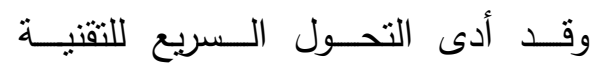
واستخدامها بصورة مكثفة في إناحسة مصادر المعلومات، وميكنة الإجراءات في المكتبة، إلي

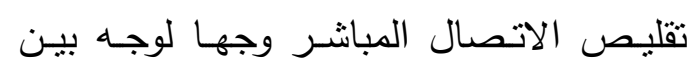
المستفبد والمكتبي، ومن ثم فقد برزت أهمية برامج الوعي المعلوماتي عبر البيئة الرقمية

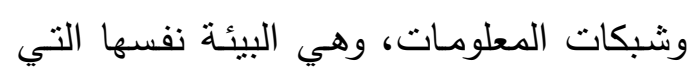
Oتعامـل معها المستفيدون. ( Orr et al., (r...)

وقد حدد شـابيرو وهيـوز "المنهـج النموذجي" الذي اشتـمل على مفـاهيم أميـة الحاسب، والمهارات المكتبية، مقترحين سبعة

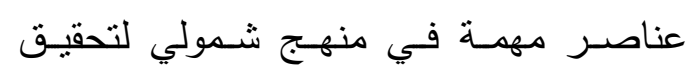
الوعي المعلوماتي. تمثلت فيما يلي: ا. الوعي بـالأدوات، أو القدرة على فيلى فهم

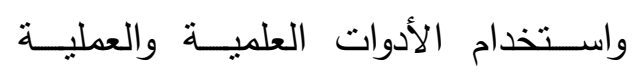
لتكنولوجيا المعلومات الحالية ذات العلاقة بالتعليم وبمجالات العمل والحياة المهنية التي يتوقع الفرد أن يحياها.

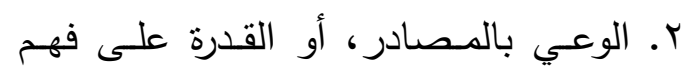

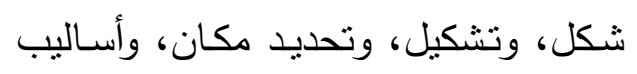
الوصول إلى مصادر المعلومـات، يوميًا من خلال موارد الشبكة.

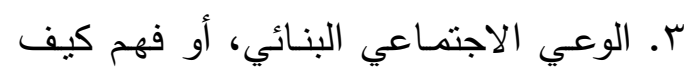
تكون المعلومة مُنتجة اجتماعيًا. 
العدد الرابع والخمسـون - 7 •

التـني الـثديد لنسبة الحـضور ببرامـج كورسبرا وغيرها من المنصات، والذي يقف عند 9 \%، وقد يكون سبيه نقص الدعم التربوي والمجتمعي.

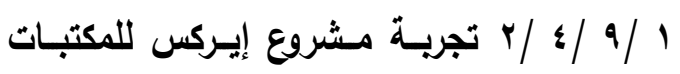
IREX's Global الكوني

\section{:Libraries project}

IREX

تقدم برامج قيادية ومبتكرة لتحسين نوعية التعليم

وتعزيز الإعلام المستقل وتتمية مجتمعات مدنية

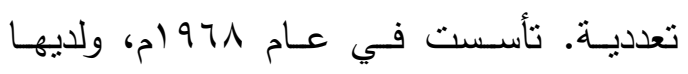

$$
\text { شراكات مع أكثر من . . } 1 \text { دولة. }
$$

وتعمـل المنظمـة في مساعدة المكتبـات

على توفير أفضل خدمة لمجتمعاتها من خلا: ا ـ تحسين فرص الحصول على المعلومـات للمـواطنين مـن خــله تزويـــ المكتبـات بالتكنولوجيا الملائمة. r. تـدريب أخصائي المكتبـات على تقديـم خدمات معلومات إلكترونية حديثة لمرتادي المكتبة.

r. تعزيـز صـوت المكتبـات على الـصعيدين الوطني والمحلي مـن خـلاد زيـادة قدرات

$$
\text { جمعيات المكتبات الوطنية. }
$$

ـ. تعزبـز الـدعم الحكومسي للاعتراف بالدور

الأساسي للمكتبـات في المجتمع الحديث.

وتلعـب المنظمـة دورًا (IREX, 2014)

كبيرًا في علاقتها بـبرامج مـوك كجسر ولـر
الكونجرس والمكتبة البريطانية)، كما أنها أحد

أهم مكتبـات الأبحـاث في الولايـات المتحدة

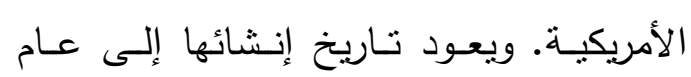
190 ام. وتضم المكتبة بكل فروعها نحو مليـون وعــاء معلومسـات. New York )

Public Library, 2014) ويتجلى دور المكتبـة في علاقتها بـ موك فيما نوفره من الدعم المؤسسي والبنيـة الأساسية

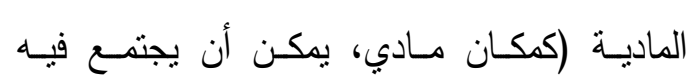

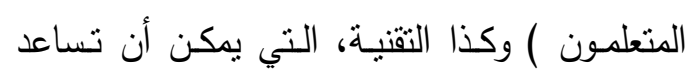
المتعلمين في الانخراط في الدورات على الإنترنت.

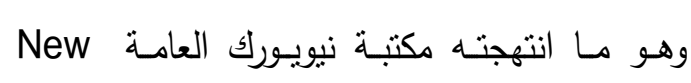
York Public Library

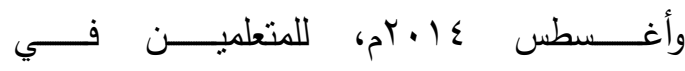
برنـامج :"تكنولوجيا المعلومـات" المقدم من خـلد منصة كورسبرا، لمدة ستة أسابيع، بواقع ، و دقيقة

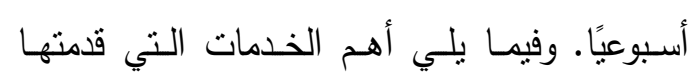
المكتبة للمتعلمين: Gashurov, Irene, Curtis) Kendrick, 11/06/2014) ا- نوفير البنيـة التحتيـة المعلوماتيـة الخاصـة بها، إضافة إلى توفير محتواها الإلكتروني والورقي.

r- توفير موقعها المادي لتجمع المتعلمين . ب- توفير ميسر متخصص من مرتادي المكتبة موفها لمساعدة المتعلمين.

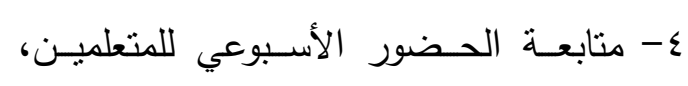
والذي وصل إلى مستويات قياسية في ظل 
يتولى قيادة ثورة موك حالبًا عدد من أكبر

المنصات منـل: كورسيرا، ويوداسـيتي، وإيـكس؛

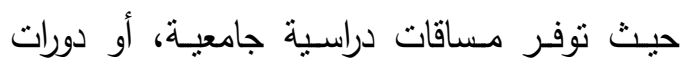

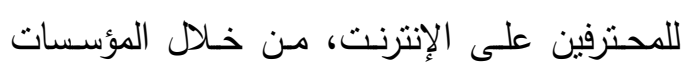

الشهيرة والرائدة المهتمـة بـالتعليم العـالي وتتيحهـا

للمتعلمين في جميع أنحـاء العـالم · وفيمـا يلي تعريف بأهمها:

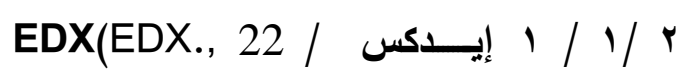
:10 /2014)

منصة مجانية، لا تهدف للربح المادي.

تستهدف إطلاق المساقات عبر شبكة الإنترنت،

أسسها معهد ماساتشوستس للتكنولوجيا وجامعة لهنة

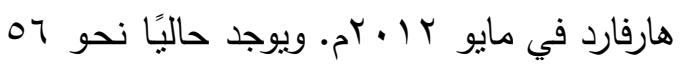
مؤسسة تعليمية تقدم مساقاتها من خلالها. وقد مايو

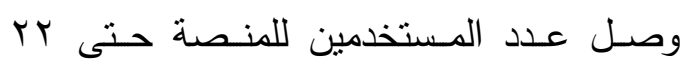

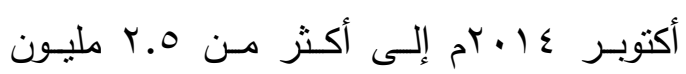
مستخدم، حصلوا على أكثر من · ع بمساقًا. وتقدم مساقات MOOCs بالتعاون مـع لدماتى

عدد مـن أفضل الجامعات في العـالم، مثل: هارفارد، وبركلي، وغيرها. وتشمل التخصصات

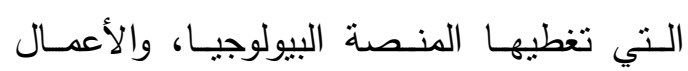

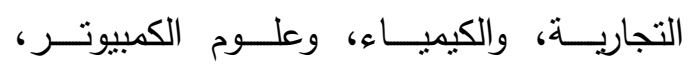

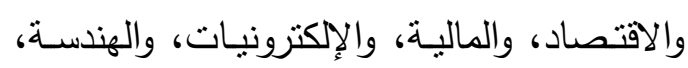

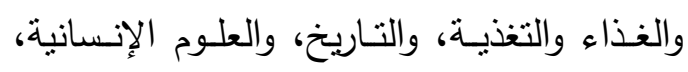

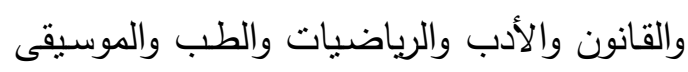
والفلسفة والفيزياء، والعلوم، والإحصاءات.

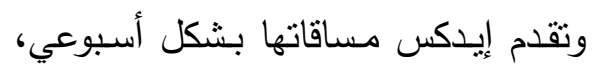

للتواصل العلمي، خاصـة في الدول النامية، ومن أبرز جهودها في هذا الإطار، تجربتان جيدنان في كل مـن: ملدوفا وهي دولـة

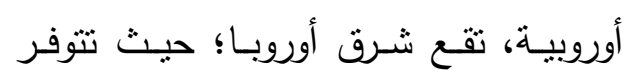

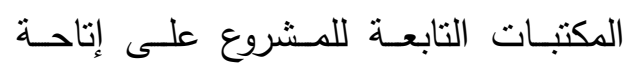
تـدريس المرتـادين بـرامج مـوك المتعلقـة

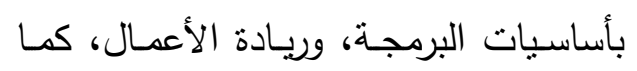
تتيح مكتبات أوكرانيا إمكانيـة التفاعل بين السيدات وخبراء الصحة فيما يتعلق بالصحة

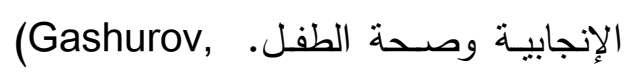
Irene, Curtis Kendrick, 11/06/2014)

1 / • 1 مساقات مـوك المقدمسة في مجـال

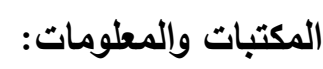

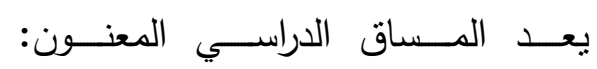

"Hyperlinked Library" دراسي قدم في مجال المكتبات والمعلومات، وهو المساق الوحيد المتخصص في المجال حتى دئى

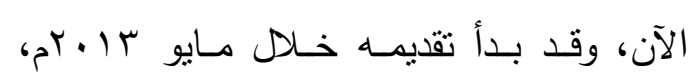
ودرسه Michael Stephens الأستاذ المساعد ولهايو بقسم المكتبات والمعلومات، بجامعة ولايـة سان San José State University جـوس

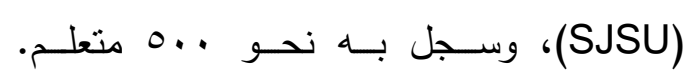
. (Schwartz, Meredith., 10/5/2013) r- الاراسة التطبيقية: r / / نمـاذج رائـدة لمنصات مـوك (النمـاذج التي سيتم التطبيق عليها): 
العدد الرابع والخمسـون - 7 •

الجامعي وعلى شبكة الإنترنت.

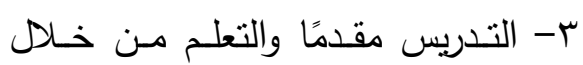

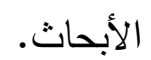

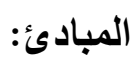

$$
\text { ا - عم الربحية. }
$$

r - منصة مفتوحة المصدر .

r- التعاون مع كافة المؤسسات المعنية

$$
\text { بالتعليم. }
$$

ع - الاستدامة المالية.

Udacity(NPR., يوداسيتي r / / r

:23 / 1 /2013), (Udacity, 2014) منصة تعليمية تهدف للربح أسسها كل

من:Debastian Thrun Stavens

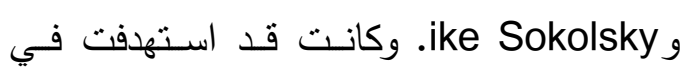
البداية تقديم مساقات دراسية جامعية، إلا أنها الآن باتــت تركـز علـى الـدورات المهنيـة

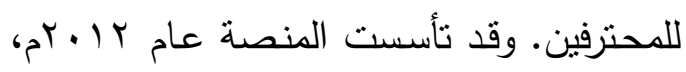
وتعتمد في تمويلها على التمويـل الاستتماري المباشـر مـن خـلال عـدد مـن المـشروعات المات الاقتصادية، بالإضـافة إلى الاستثمار من قبل أحد مؤسسيها، وهو Thrun

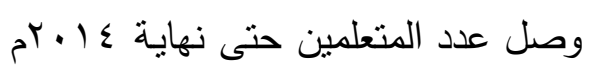

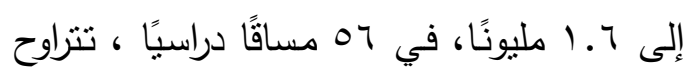

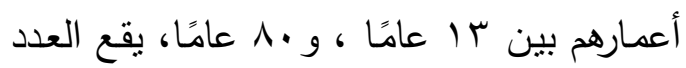

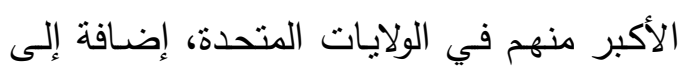

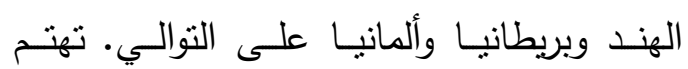
المنصة بالمسـاقات الدراسـية الجامعيـة، وكـا
بمعدل من 0 إلى V أسـابيع للمساق، بمتوسط • 1 دقائق للمحاضرة، التي تحوي أثرطة فيديو، تتخللها تمـارين تعليميـة تفاعليـة، كمـا تحتوي المساقات على إحالات إلى مصادر إلكترونية،

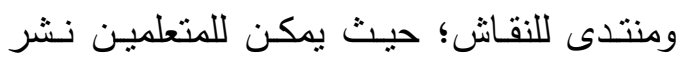
ومراجعـة الأسئلة والتعليقات مـع غيرهم بشكل تفاعلي. وتقدم المنـصة نـوعين مـن الـشهادات للمتعلمين، هما:

- الثهادة المجانية، وهي شرفية، لان يتم الالتحاق بالوظائف من خلالها. - الشهادة مدفوعـة الأجر ، ويمكن

$$
\text { الحصول على وظيفة من خلالها. }
$$

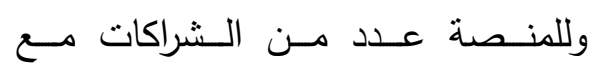

المؤسـسات التعليميـة فـي الولايـات المتحـدة، ونـات

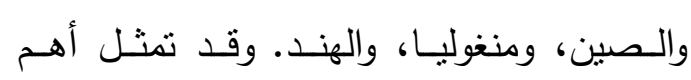
المساهمين في المنصة في جامعات: ستانفورد، وكامبردج، وكاليفورنيـا في بيركلي، وهارفارد،

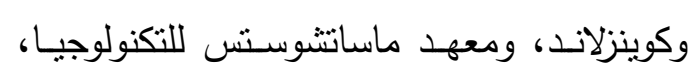

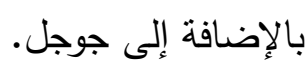
الرسالة: تحقيق أعلى درجات الجودة في التعليم،

سواء عبر الإنترنت، أو في الفصول الدراسية. الأهداف:

1- توسيع فرص الحصول على التعليم للجميع. ץ- تعزيـز التعليـم والتعلـم في الحـرم 
الجينـوم، والـصحة العامـة، وعلـوم الفضاء،

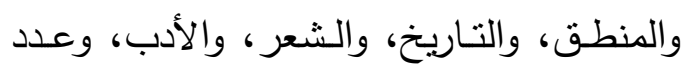

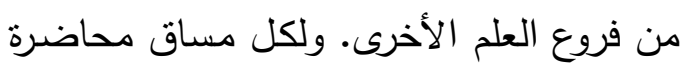
على الفيـديو (مترجمـة باللغـات الفرنسية، والإيطاليـة، والتركيـة، والإسـبانية، والـصينية،

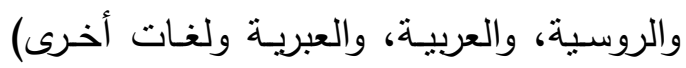
ومهام على المتعلـم إتمامهـا. وتعتمـد في اختباراتها على نظام تقييم الأقران ـ كما توفر كورسيرا لكل مساق مجالات للنقاش. ويعتمد بعض المتعلمين على الالتقاء فيما بينهم في أماكن جغرافيـة محددة من خـلال نظام "مينتج دوت كوم". وتعتمـد نظم ديناميكيـة الضغط على المفاتيح للتأكد من مصداقية الطـلاب (Coursera., About,2014) . والمساقات المقدمـة من خـلال كورسيرا هي المناهج الدراسية الخاصة بأكثر من . . 1.

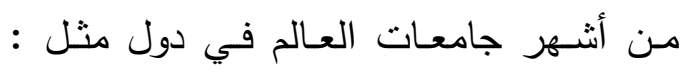
الولايات المتحدة الأمريكية، وكندا، وأستراليا، وإنجلتزا، والصين، وروسيا، واليابان، وتركيا،

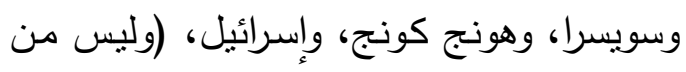
بينها دولة عربية) من بينها جامعات جونز ونز

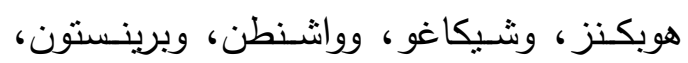

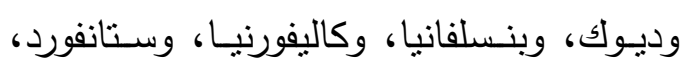

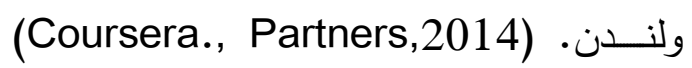
وحتى نهاية \ 1 • ب م يدرس عبر هذه المنصة

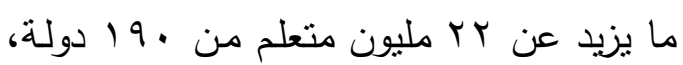
مسجلين على الأقل في مساق تعليمي واحد،
بالدورات المتخصصة في مجال الحاسب الآلي، نتيجـة الشراكة مـع مؤسسات: جوجل، ونفيديا، ومايكروسوفت، وأوتوديسك، مـع وجود مساقات مؤنسات حول الجبر والإحصاء والائتمان. رسالة يوداسيتي:

نشر التعليم، وتيسير الوصـول إلبـه،

بأسعار معقولة، وتحقيق المشاركة الفعالة، بما يكفل تمكين الطـلاب من النهوض بحياتهم

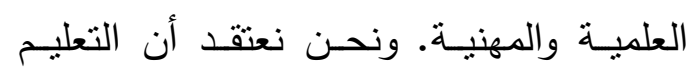
العالي هو حق أساسي من حقوق الإنسان.

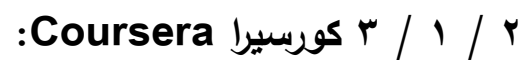
شركة تقنية تربوية ربحية (رغم أنها في بدايتها لم تستهدف الربح) توفر مساقات هائلة

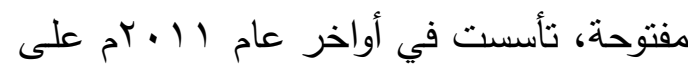
يدي أستاذين جامعيين في علوم الكمبيوتر في

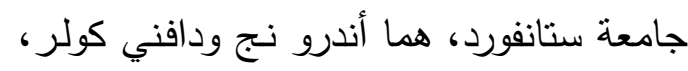
بعد أن لاحظا أنسه في وقت سـابق من تلك فئك السنة، سـجل بجامعة ستانفورد حوالي ل . 1. ألف طالب في مقررات تعليمية على الإنترنت كانت الجامعة قد طورتها. (McConnell, Kathryn, 18 / 12/ 2012) وينتـح هـذا الموقع عـدًا كبيرًا مـن المساقات الدراسـية تصل إلى هـ مساقاً دراسيًا، (من المخطط أن تصل إلى ....

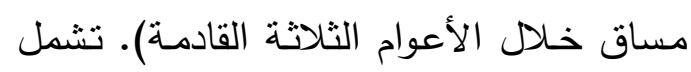

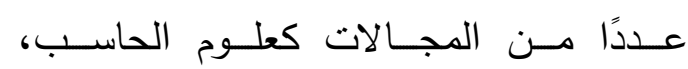
والإحصاء، والرياضيات، والاقتصاد، وعلوم 
العدد الرابع والخمسـون - 7 •

ع - التعلم المختلط. (الدمج بين التعليم التقليدي، وجهاً لوجه، والتعليم عبر الإنترنت).

(Coursera., About ,2014)

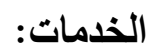

من الخدمات التي يقدمها مشروع كورسيرا ما يلي:

1- إمكانية الحصول على شهادات معتمدة من

الموقـع، يحـصل عليهـا الطالب المؤهـل

مقابل قيمة مادية.

r- بيـع معلومـات وبيانـات عـن المتعلميـن

المشاركين لشركات يمكنها الاستفادة منها

سواء في برامج تسويقية أو إحصائيات أو

غيرها.

ب- إمكانيـة نقييـم المتعلميـن المـشاركين في أحـد

المساقات، أو الدورات بطلب مـن شـركات أو

مؤسسات، وذلك مقابل دفع فيمة مالية معينة

لكورسيرا لتقييم متعلمين بعينهم لغرض تعبينهم أو الاستفادة من مهاراتهم.

ع- إمكانية دفع قيمـة مالية لأحد العاملين في

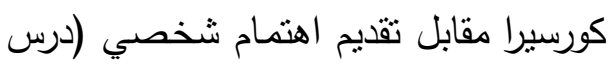

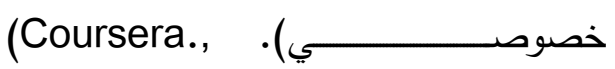

.Services ,2014)

r / r معايير التعلم عبر موك، بالتطبيق على

المنصات الدولية (عينة الدراسة):

فيما يلي تطبيق معايير التعلم عبر موك،

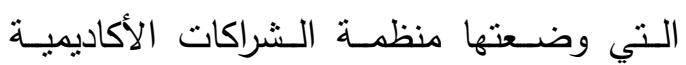

Academic Partnerships, AP
أمسضوا نحسو ..ع مليـون دقيقـة تعليميـة،

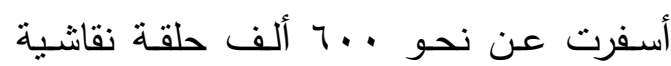
..(Coursera., Community,2014) . وبـالطبع الـرقم يزيد كل عدة ثوانٍ! وتأني الولايـات المتحدة في المركز الأول من حيث

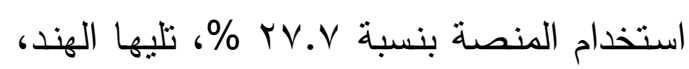

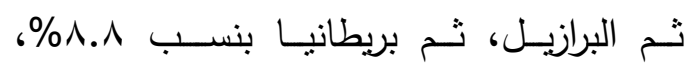

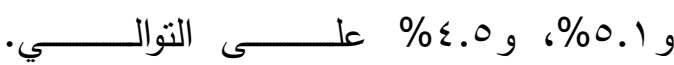
.(Balch,Tucker , 2014)

وقد جذبت الشركة عند تأسيسها r r مليون دولار مـن خـلاص رجـال الأعمـال، الـذين يمولـون المشاريع الرائدة، ومسن شركاء الجامعات. ممـا أتاح

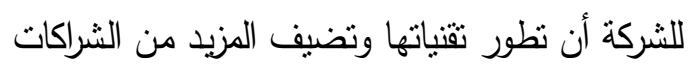
الجامعية كي تتمكن من الوصول إلى عدد أكبر من

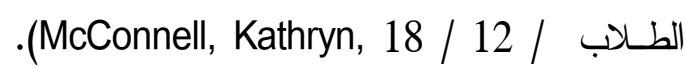
2012)

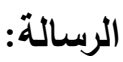
تقديم تعليم فعـال عبر الإنترنـت، مسن خـل شراكات مـع أكبر مؤسسات التعليم في نعاي العالم، مجانًا. (Coursera., About 2014)

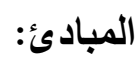
للقيام بالرسالة السابقة فإن المنصة تعدل على تحقيق أربعة مبادئ، هي: 1- تقديم تعليم فعال عبر الإنترنت. r- التعلم بهدف الوصول للإتقان. r- ثقييم الأقران. (من المتعلمين في نفس بل (المساق) 
تلعبب مقدمـة المساق، وملامحسه العامـة

دورًا مهمًا في تحقيق الهدف الأساسي لله؛ فهي

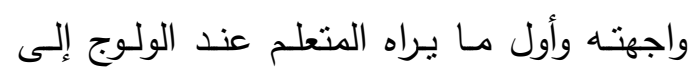
المساق، ومسن ثم يـرتبط هذا المعيـار بكيفيـة

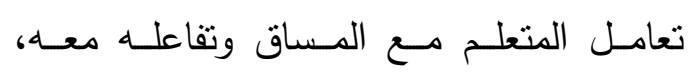
ووصـوله إلـى المعلومـات والخـدمات المقدمـة بسهولة ويسر دون حاجـة إلى تدريب. ومدى ولى إلى

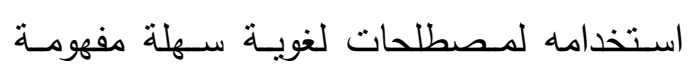
يستطيع من خلالها أن يـألف الموقع. واحتواء المقدمة على أكبر قدر من المعلومات المباشرة

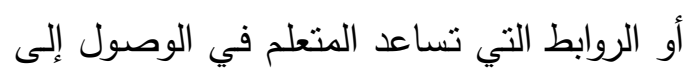

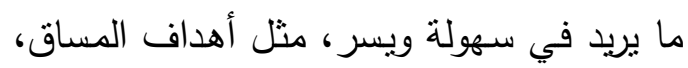

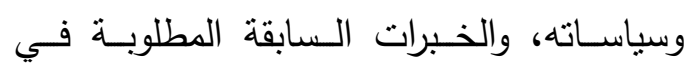

ثمانية بنود، والمطروحة في أربعين عبارة على

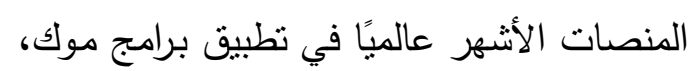
ولا يستهدف هذا التطبيـق الوصـول إلى أكفأ

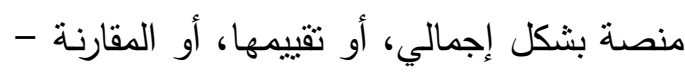

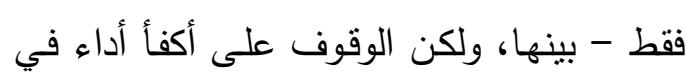
كل بند من البنود الثمانيـة، أيًَا كانت المنصة الثها صاحبة هذا الأداء، ومن ثم استعراض أدائها في

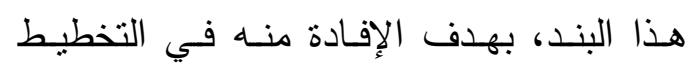
للمنصة العربية. أولاً: المعـايير الخاصــة بمقدمــة المـساق

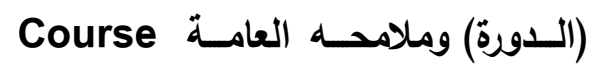

\section{:Overview and Introduction}

جدول رقم (0)

المعايير الخاصة بمقدمة المساق (الدورة) وملامحه العامة (؛) (•)

\begin{tabular}{|c|c|c|c|c|c|c|c|c|c|}
\hline \multicolumn{3}{|c|}{ كورسيرا } & \multicolumn{3}{|c|}{ إيدكس } & \multicolumn{3}{|c|}{ يوداسيتي } & \\
\hline غوافير & محايد & موافق & غوافير & محايد & موافق & غوافير & محايد & موافق & \\
\hline$\% r$ & $\% r$ & $\% 97$ & $\%$ & $\% r$ & $\% 9 \leq$ & $\% 0$ & $\%$ & $\% 94$ & 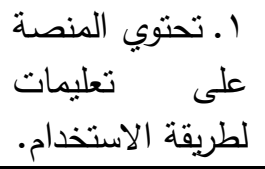 \\
\hline$\% 1$ & $\% r$ & $\% 9 \vee$ & $\% r$ & $\% r$ & $\% 90$ & $\% r$ & $\%$ & $\% 9 \varepsilon$ & 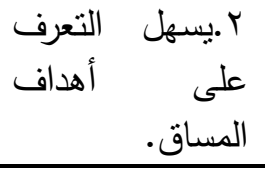 \\
\hline$\% r$ & $\% r$ & $\% 9 \leq$ & $\% \leq$ & $\% r$ & $\% 9 \leq$ & - & $\% \vee$ & $\%$ \% & الما تلحتوي المنصة \\
\hline
\end{tabular}


العدد الرابع والخمسـون - 7 •

\begin{tabular}{|c|c|c|c|c|c|c|c|c|c|}
\hline$\%$ & $\% 1$ & $\% 97$ & $\% 0^{\circ}$ & $\% r$ & $\% 94$ & $\% \Gamma$ & $\% r$ & $\% 90$ & بالوضوح. ت الستم السياسات \\
\hline$\% 1$ & $\% r$ & $\% 9 V$ & $\% 0^{0}$ & $\% 0^{\circ}$ & $\% 9$. & $\%\urcorner$ & $\% r$ & $\% q r$ & 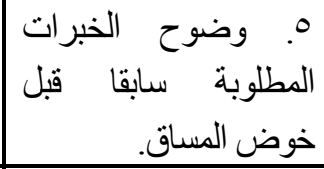 \\
\hline$\% 7$ & $\% r$ & $\% 9 r$ & $\% \varepsilon$ & $\% r$ & $\% 9 \varepsilon$ & $\% 0^{\circ}$ & $\% r$ & $\% 94$ & 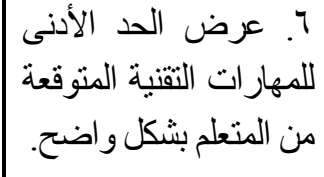 \\
\hline- & $\% r$ & $\% 91$ & - & $\% \wedge$ & $\% 9 r$ & - & $\% r$ & $\% 9 \vee$ & 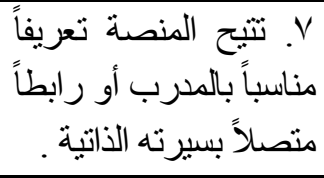 \\
\hline- & $\% r$ & $\% 9 \vee$ & $\% r$ & $\%\urcorner$ & $\% 9 r$ & $\% 7$ & $\% 1$ & $\%$ \% & 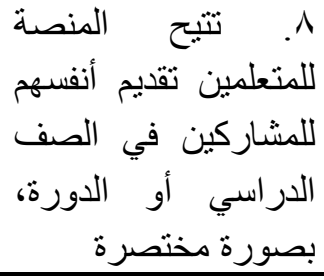 \\
\hline$\% r$ & $\% r$ & $\% 97$ & $\%$ & $\% \varepsilon$ & $\% 9 r$ & $\%$ & $\%$ & $\% q \leq$ & المتوسط \\
\hline
\end{tabular}

أيقونـة (استعراض المساق) للمسجلين في المساق، وبمجرد الضغط عليها يتم التوجها إلى لوحة المعلومات التي تتضمن محتويات

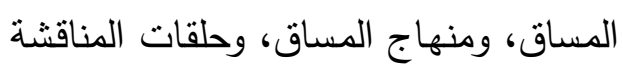
والمزيد. ץ- سهولة التعرف على أهداف المساق؛ حيث تتاح على الصفحة الرئيسية للمساق، وتتسم باتـساقها مـع محتوى المسـاق، وشـمولها وتدرجها، خاصـة مـع وجود نماذج إرشـادية

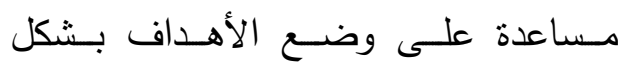

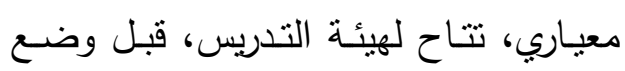

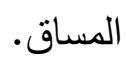
r- تحتوي المنصة على قواعـد للسلوك،
المتعلم، ومعلومات عن هيئة التدريس، ومزبـج من القواعد السلوكية والأخلاقية . ومسن خـلال الوقوف على واقع منصة كورسبرا كأعلى منصة حصلت على درجات

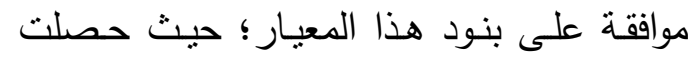

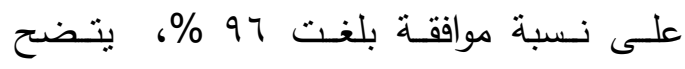
الاتساق بيـن النتائج السابقة وواقع المنــة حيث تتسم مقدمـة المساقات وملامحها العامـة التي تتيحها البيئة الافتراضية لكورسيرا، بما يلي: 1- وضـوح التعليمـات الخاصــة بطريقــة

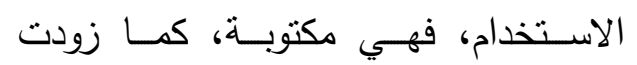
المنـصة بملـف فيـديو تعليهـي لطريقـة فئة استخدام المنصة، فعند بدء المساق ستظهر لئر لئر 
والـشمول؛ حيـث تشنتمل على معلومـات واضـحة ووافيـة عن السياسـات الحاكمـة لـ: شروط الاستخدام، والقيود العمريـة (الأعمار المسموح بهـا) ، وإخـاء المسئولية، وحق التعديل، وحسابات المستخدمين، وسياسـة الخصوصــية، وسياســة حقـوق التأليــ والنششر، والمسساقات والـشهادات، والرسـوم والضرائب، وسياسة رد مقابل التشجيل...

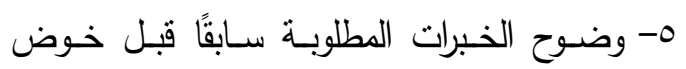
المساق؛ حيث بحدد كل مساق المنطلبات القبلية لاراسـته، وهـي غالبَّا في صـورة عـدند مـن المساقات، أو المقررات التي ينبغي أن يكون المتعلم على علم بها قبل بدءء المساق، وهي لبـي

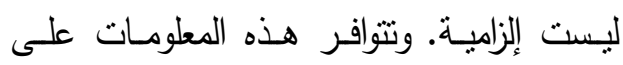
الصفحة الخاصـة بالمساق. كمـا بمكن للمتعلم طرح هذا السؤال على المنتدى ليحصل على لئ اقتراحات من الزملاء أو المشرفين على المساق. وليوداسيتي روئة جيدة في هذا الإطار (رغم أنها لم تحصل على أعلى الدرجات في هذا البند)؛ حيث تصنف البرامج إلى برامـج "المبتدئين Beginner classes "، "المتوسطة Most Intermediate classes Advanced courses وفقاً للمعرفة المسبقة بالموضوع. - وتتاسب الأولى الأفراد ممن ليس لديهم

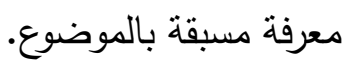
- أما المتوسطة فتتطلب بعض المعرفة بلهوفئ
والممارسـات الأخلاقيـة، وهي متاحسة على . واجهة المنصة، إضافة إلى ميثاق الثرف، وهو تعهد يقدمسه المتعلم، يقر من خلالهـ بالالتزام بالقوانين والأخلاقيات التي تحددها المنصة لضمان عملية تعليمية سلسة وذات مستوى عال. وتؤكد قواعد السلوك على ضرورة تحاشي المتعلمين لما يلي: - المحتوى الـذي يـشهر بـالآخرين، أو يضايقهم أو يهددهم.

- المحتوى الذني ينتهـك حقوق الملكيـة الفكريـة، مثنل حقـوق التـأليف والنشر والعلامات أو الأسرار التجارية. - المحتوى الذي لا يجوز للمتعلم الكشف لهمبل عن سريته بموجب التزامات تعاقديـة أو واجبات محددة. - المـواد التي تحتوي على فاحشة (أي الإباحية) لغة أو صورًا. - الإعلانـات، والمـواد الترويجيـة، أو أي الإبـان شكل من أنثكال الإغراء التجاري. - المحتوى الـذي ينـاقش أنسشة غيـر مسشروعة بقصد ارتكـاب مثنل هـذه

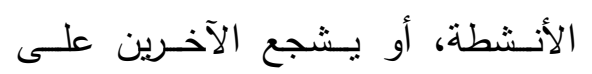
ارتكابها. - المحتوى الذي يزرع البرمجيات الخبيثة، أو يؤذي الموقع، أو أحد المستخدمين. ع - تتسم السياسات الخاصة بالمنصة بالوضوح 
العدد الرابع والخمسـون - 7 •

الفرد إلى تحقيقها، وأهداف التعلم في البيئة الإككترونية هي نتائج أو حاجات محددة مرغوبة أو مطلوب تحقيقها في فترة زمنية محددة. فهي متعلقة بما يجب إنجازه ... أو ما تسعى المنصة إلىى تحقيقهـ، متمنلـة في الأهـداف المعرفيـة

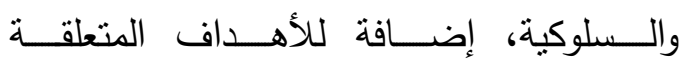
بالاتجاهـات، وتكمن أهميـة هذه الأهداف في تحديدها لمسارات أنشطة التعلم واستراتيجياته، وصـولاً إلى أسـاليب التقييم والقيـاس وأدواتـه .

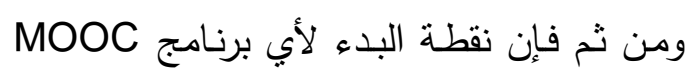

$$
\text { هي تحديد الأهداف. }
$$

وينبغي أن تتسق أهداف المساق مـع فلسفته والمحتوى التعليمسي وطبيعـة العصر ومجتمـع لتصع

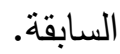 - أما المتقدمة فتتطلب معرفة كبيرة بالموضوع. - بالموطوع. - ويمكن الوصول إلى معلومـات عن المتطلبات القبلية للاراسة من خلال قسم "What do I ماذا أريد أن أعرف؟ " في نفس الصفحة. צ- عـرض الحـد الأدنـى للمهـارات التقنيـة

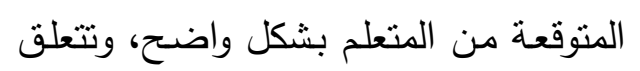

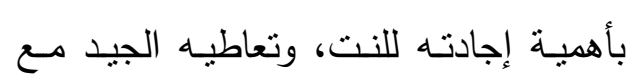 شبكات التواصل الاجتماعي، كحد أدنى.

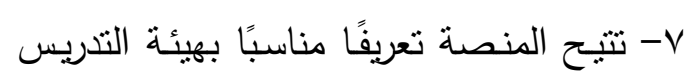

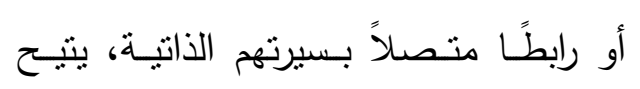

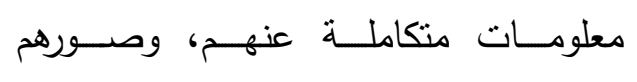
الشخصية، وسبل التواصل معهم. 1 تتيـح المنــة للمتعلميـن تقديم أنفسهم للمشاركين في المساق الدراسـي، بـصورة مختصرة، مـن خـلال لوحـة المعلومـات الخاصـة بهم، التي يمكنهم الوصـول إليها من خـل تسجيل البريد الإلكتروني وكلمة لهنة المـرور، ويمكن للمتعلم مـن خـلال لوحته

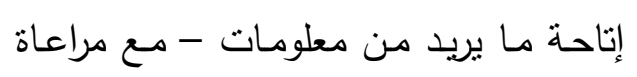

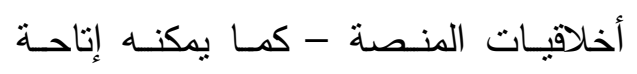
صورته الثخصية كذللك. Learning ثانياً: أهداف التعلم و الكفاءات كندات Competencies\&Objectives الهدف بصفة عامة هو الغاية التي يسعى 
جدول رقم (7)

أهداف التعلم و الكفاءات

\begin{tabular}{|c|c|c|c|c|c|c|c|c|c|}
\hline \multicolumn{3}{|c|}{ كورسيرا } & \multicolumn{3}{|c|}{ إياكس } & \multicolumn{3}{|c|}{ يود/سيتي } & \\
\hline موأفيّق & محاي & موافق & موافقير & محايد & موافق & موافقير & محايد & موافق & \\
\hline$\% 10$ & $\% \Lambda$ & \%VV & $\% \backslash \varepsilon$ & 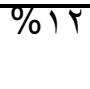 & $\% \vee \varepsilon$ & $\% \vee$ & $\% \backslash V$ & $\% \vee 7$ & للقياس. أهداف التعلم قابلة \\
\hline$\% \varepsilon$ & $\% \wedge$ & $\% \wedge \wedge$ & $\% 7$ & $\% r$ & $\% 9 r$ & $\% r$ & $\% \Lambda$ & $\% 9$. & 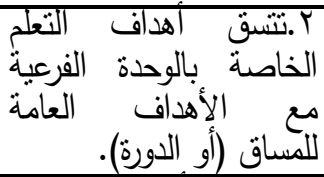 \\
\hline$\% \Gamma$ & $\% 9$ & $\% \wedge \wedge$ & $\% Y$ & $\% \wedge$ & $\% 9$. & $\% Y$ & $\% r$ & $\% 97$ & بالمنطقية. \\
\hline$\% r$ & $\begin{array}{l}Y \\
\% \\
\%\end{array}$ & $\% \vee 7$ & $\% \circ$ & \%Yr & $\% \vee r$ & $\% r$ & $\%$ \% . & $\% \vee V$ & 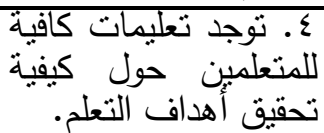 \\
\hline$\% r$ & $\begin{array}{l}T T \\
\%\end{array}$ & $\% \vee 0$ & $\% r$ & \%Yr & $\% \vee 7$ & $\% 1$ & $\%$ \%T & $\% \vee \wedge$ & 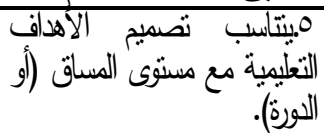 \\
\hline$\% 0$ & $\% 1 \varepsilon$ & $\% \wedge 1$ & $\% 7$ & $\%$ & $\% \wedge 1$ & $\% \varepsilon$ & $\% \backslash \varepsilon$ & $\% \wedge r$ & المتوسط \\
\hline
\end{tabular}

وجود اتساق - أيضًا - بين أهداف المساق

والتقويم. خاصـة وأنـه توجد قواعد إرشـادية

تتيح معايير الأهداف التي ينبغي مراعاتها،

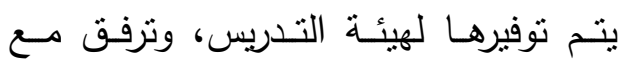

المخطط.

r- القابلية للقياس.

r- العمليـة والواقعيـة؛ حيث ترتبط في قطاع

منهـا، بمـدى توظيـف المسـاق لخدمسة

المتطلبات الحياتية.

ع- التسلـسل المنطقي والجدولـة الزمنيـة؛ حيث

يرتبط تحقيق كل هدف - سواء على مستوى

المساق ككل، أو على صعيد الوحدات الفرعية

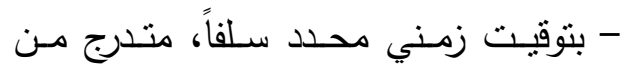

المعرفـة، كما ينبغي أن تتسم بالشمول والتتوع والتوازن والواقعية، مع القابلية للتحقق.

ومسن خـلال الوقوف على واقـع منصة

إيدكس كأعلى منصة حصلت على درجات موافقة على بنود هذا المعيار ؛ حيث حصلت

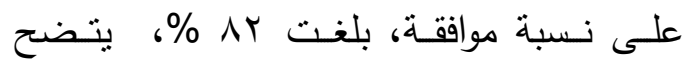
الاتساق بين النتائج السابقة وواقع المنصة؛ ومن خلا الولوج إلى عينة عشوائية من المساقات،

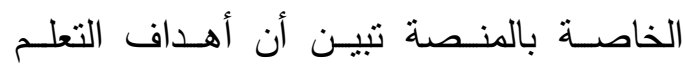
المطروحة بالمساقات تتسم بما يلي: 1- الاتساق بين أهداف المساق عامة وأهداف باف لهات الوحدات الفرعيـة، مـع وجـود اتساق بيـن الأهداف والمحتوى، كما أبرزت المؤثـرات 
العدد الرابع والخمسـون - 7 •

وضـوح الأهداف، وتوازنها، واتساقها الداخلي الأبسط إلى الأصعب.

$$
\text { والخارجي. }
$$

0- وجـود تعليمات - غير مباشـرة - تمكن

ثالثًا: التقييم وإلقياس Assessment and المتعلميـن مـن تحقيـق الأهداف، مرتبطــة

\section{:Measurement}

التقييم في البيئة الإلكترونية هو عملية

منهجية تقوم على أسس علمية، تستهدف إصدار الحكم - بدقة وموضوعية - على مدخلات البرنامج وعملياته ومخرجاته، اعتمادًا على كل من التقييم الآلي وتقييم الأقران. ومن ونانه ثم فإن الغاية من التقييم هو الوقوف على مدى

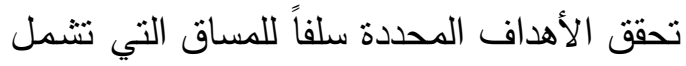
اكتساب المعارف والمهارات والاتجاهات. ويتعلق التقييم والقياس بتوافر معايير

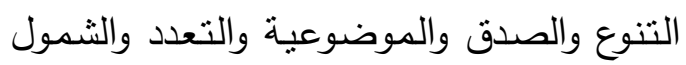

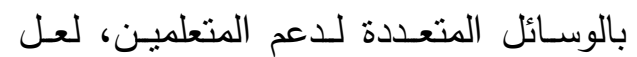
أنثـرها توفير التفاعل المباشـر من خـلاص النواصل مع هيئة التدريس، وإدارة المنصة. إضـافة إلى إتاحة منتدى لكل مساق، ينتح للمتعلم إمكانية النواصل مـع الزملاء وهيئة

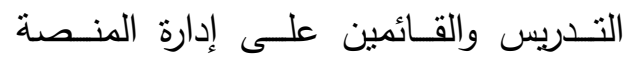
ومناقشتهم في مختلف القضايا المتعلقـة بالمساق الدراسي، وسبل تحقيق أهدافه. ويؤكد على أهمية معايير جودة أهداف

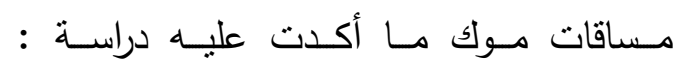
من ضرورة (Kazakoff, Carmen, 2014 )

جدول رقم (v)

التقييم والقياس

\begin{tabular}{|c|c|c|c|c|c|c|c|c|c|}
\hline \multicolumn{3}{|c|}{ كورسيرا } & \multicolumn{3}{|c|}{ إيدكس } & \multicolumn{3}{|c|}{ يوداسيتي } & \\
\hline غوافير & محايد & موافق & موافقير & محايد & موافق & موافقير & محايد & موافق & \\
\hline$\% r$ & $\% V$ & $\% 9$. & $\% r$ & $\% 4$ & $\% 94$ & $\%$. & $\% 4$ & $\% \wedge \varepsilon$ & 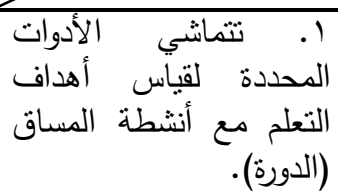 \\
\hline - & $\% r$ & $\% 91$ & - & $\% r$ & $\% 9 \wedge$ & $\% 1$. & $\% r$ & $\% 9 \mathrm{~V}$ & 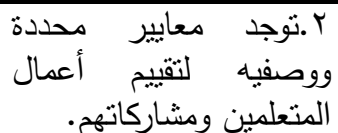 \\
\hline$\% 7$ & $\% r$ & $\% 91$ & $\% r$ & $\% 0$ & $\%$ \%र & $\% 1$ & $\% 1$. & $\% \wedge 9$ & r.بتتس أدوات التقييز بالتنسلسل. \\
\hline$\% r$ & $\% r$ & $\% q \varepsilon$ & $\% r$ & $\% r$ & $\% 97$ & $\% r$ & $\% r$ & $\% 90$ & ع. تتسم أدوات التثقيبم بالتتوع. \\
\hline$\% 0$ & $\% 1$ & $\% q \varepsilon$ & $\% r$ & $\% r$ & $\% 94$ & $\% 0$ & $\% r$ & $\% 94$ & 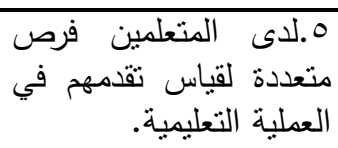 \\
\hline$\% r$ & r.o & $\% 94.0$ & $\% 1.0$ & $\% \varepsilon .0$ & $\% q \varepsilon$ & $\% ץ .0$ & $\% 0$ & $\% 91.0$ & المتوسط \\
\hline
\end{tabular}


أسئلة الاختيـار مـن متعدد والأسئلة ذات والثفافية، والاتساق مع الأهداف.

$$
\text { الإجابات القصيرة. }
$$

r- لدى المتعلمين فرص متعددة لقياس تقدمه في العملية التعليميـة؛ حيث يمكن للمتعلم حل نفس الاختبار ثناث مرات، وتحتسب له له

$$
\text { الدرجة الأعلى. }
$$

ع- توجد معايير محددة ووصفيه لتقييم أعمال

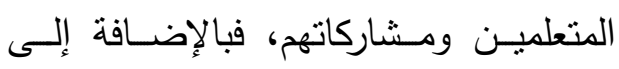

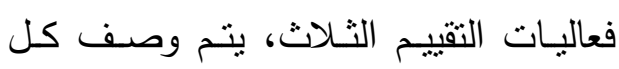
فعالية على حدة، وعلى سبيل المثال في الأسئلة مفتوحسة: توضـح المنصة الحقائق

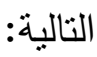

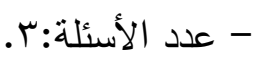

$$
\text { - النسبة المئوية: } 010
$$

- الهـدف: تشجيع التفكير الإبـداعي،

وتستتد أجوبتها إلى المعرفة المكتسبة المبة

فـي المسـاق، إضـافة إلـى خيـال

المتعلمين وتجاربهم الثخصيّة.

- التوقيـت: يعطى موعـد الاختبـارات

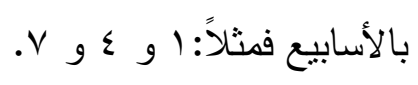

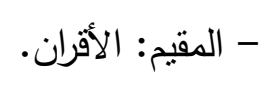

- تدرج الـرجات: للحصول على " شهادة

إنهاء " ينبغي الحصول على درجة نهائية

\% .

إنهاء بامنياز" ينبغي الحصول على درجة ولئ

$$
\text { نهائية . 9\% أو أكثر. بأن }
$$

0- تتسم أدوات التقييم بالتسلسل المنطقي؛ حيث
ومن خلال الوقوف على واقع منصة إيككس

كأعلى منصة حصلت على درجات موافقة على بنود هذا المعيار ؛ حيث حصلت على نسبة موافقة، بلغت ؟9 \%، بتضح الاتساق بين النتائج السابقة وواقع

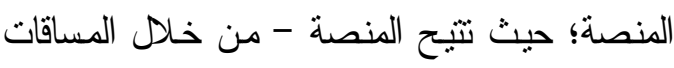

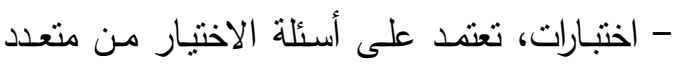

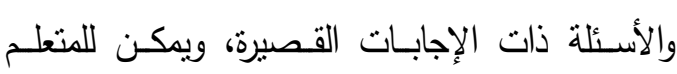
الاطلاع على نتيجته في نهايـة حله للاختبار ، من خلال صفحة تسجيله، أو تظهر لله تلقائيًا في نهاية

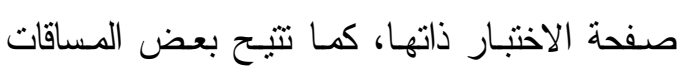

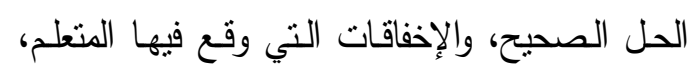
وتتيـح بعض المساقات إمكانيـة حل الاختبـار دون أدنى مشكلة، إلا أن البعض يسمح بذللك، مع خصم

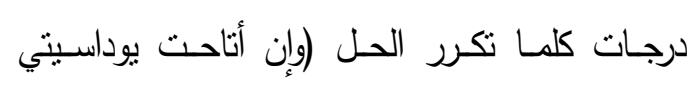
إمكانية الحل أكثز من مـرة دون عقوبات)، ويمكن للمتعلم المتشكك في درجاته مراجعة إدارة المنصة، التي يمكن أن تتصفه لو كان له حق.

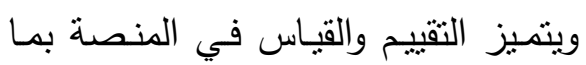
1- تثماشـي الأدوات المحددة لقيـاس أهـداف التعلم مع أنشطة المساق (الدورة).

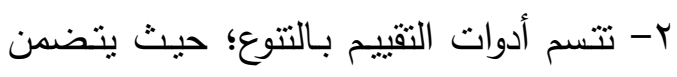
المساق ثخلاث فعاليات أساسيه قابلة للقياس هـي: الاختبـارات الأسـبوعية، والأسـئلة المفتوحة، ومشروع الإنهاء، كما تتتوع بين 
يمثل إعداد المحتوى التعليمي عبر موك

منظومـة منكاملـة تضم مجموعـة مـن المراحل

تتجـز مـن خــلال متخصـصنين في جميع

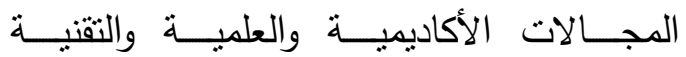

والفنية .وبنقسم الإعداد إلى ثلاث مراحل رئيسة

تبدأ بالتخطيط، ثم التصميم، وتتتهي بالإنتاج. والمحتوى التعليمي المستخدم في موك لـه به له

سمات ومواصفات خاصـة تمبزه عن المحتوى

التعليهـي المستخدم فـي الأنظمـة التعليميـة

التقليدية، أهمها استخدام أسلوب التعليم الذاتي،

لذلك فإن عملية إعداد المحتوى تتطلب قوى بشرية ذات كفاءات خاصـة، وعليه لا بد أن يتم إعداد المحتوى اعتمادًا على النماذج التي تقدمها فرق الدعم العاملة بالمنصة للأساتذة والمدربين، وهـي فـرق مسن المتخصـصبن فـي التربيـة وتكنولوجيـا التعليم، والتقويم، وفنيين في نظم

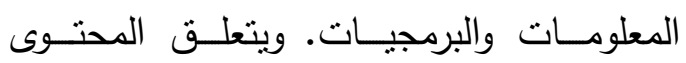

تبـدأ بالاختبـارات الأسبوعية (ابتـداء مـن الأسبوع الأول)، وتتوسطها الأسئلة مفتوحة، وتختتم المساق من خلال مشروع الإنهاء.

وتجدر الإثـارة إلى وجود نوعين أساسبين

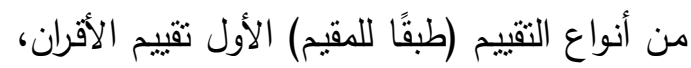
والثاني التقييم الآلي، ويفضل البعض النوع الثناني، اعتقادًا منهم بأنه الأكثر موضوعية، وهو ما أسفر

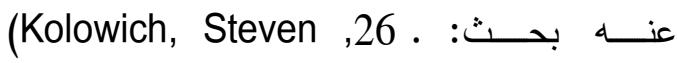
March 2013) واقع التعليم العالي وتفاعله مع موك، وطبق على منصات إيدكس، ويوداسيتي، وانتهى - فيما يتعلق

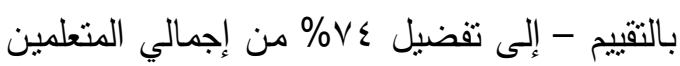
التقييـم الآلسي، مقارنـة بتفضيل عب \% لتقبيـم

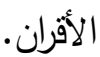

وهناك علاقة بين التزام المتعلمين بحل الاختبارات الأسبوعية، وإنهاء الدورات، ومن ثم لثرات بهن الحصول على الشهادة، وهو مـا توصـل إلبـه تقرير Duke University الذي طبـق على Bioelectricity: A Quantitative " مسساق Approach

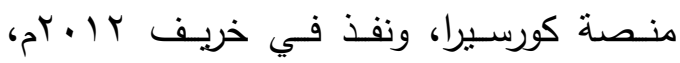
وانتهى إلىى أن هب \% مـن المتعلميـن الذيـن أجابوا على سؤال واحد صحيح كحد أدنى من الن الني اختبار الأسبوع الأول، حصلوا على الشهادة، وكان عددهم rاس طالبًا من Vr دولة، ( Duke ) .(University Report, Feb. 2013 رابعًا: المحتوى التعليمي: 
جدول رقم (^)

المحتوى التعليمي

\begin{tabular}{|c|c|c|c|c|c|c|c|c|c|}
\hline \multicolumn{3}{|c|}{ كورسيرا } & \multicolumn{3}{|c|}{ إيدكس } & \multicolumn{3}{|c|}{ يود اسيتي } & \\
\hline موأفير & محايد & مواقق & موافِقِير & محايد & موافق & موافِير & محايا & موافق & \\
\hline$\% V$ & $\% 0$ & $\begin{array}{c}\% \wedge \wedge \\
\% \curlyvee\end{array}$ & $\% \mathrm{~V}$ & $\% \Gamma$ & $\% 9$. & $\% 7$ & $\% \Gamma$ & $\% 91$ & 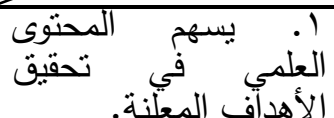 \\
\hline$\% r$ & $\% \wedge$ & $\% 9$. & $\% 9$ & $\% Y$ & $\% \wedge 9$ & $\% 0$ & $\% \Gamma$ & $\% 94$ & 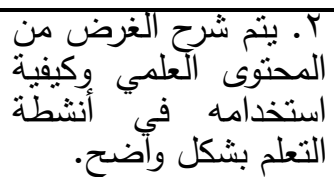 \\
\hline$\% \Gamma$ & $\% 1$. & $\% \wedge V$ & $\% 11$ & $\% T$ & $\% \wedge \vee$ & $\% \varepsilon$ & $\% \wedge$ & $\% \wedge \wedge$ & 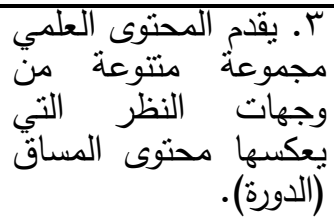 \\
\hline$\% \varepsilon$ & $\% \wedge$ & $\% \wedge \wedge$ & $\% 9$ & $\% Y$ & $\% \wedge 9$ & $\% 0$ & $\% 0$ & $\% 9$. & المتوسط \\
\hline
\end{tabular}

r- تغطية المحتوى للأهداف والأفكار والمفاهيم

$$
\text { والسلوكيات المتضمنة في المساق. }
$$

ع- الترابط والتكامل بين الخبرات التي يقدمها

$$
\text { محتوى المساق. }
$$

ه- يرتبط بالمهارات الحياتية وإدارة الحياة بصفة

عامة.

ج- مراعـاة التنظيـم والتسلـسل المنطقي في

$$
\text { عرض المحتوى. }
$$

V خلو المحتوى من أخطاء التكرار - خ

ᄉ- تتظيم المحتوى في شكل خطوات منتابعة هنة

$$
\text { وفق تسلسل منطقي. }
$$

9- تجزئة المحتوى إلي فقرات قصيرة منرابطة

$$
\text { تحقق أهداف التعلم. }
$$

وللمحتـوى التعليهـي فـي مـوك أهمبـة

Canvas ": خاصــة، ففـي دراســة أجرتهــــا
التعليمسي بمعـايير الثراء والتتـوع والاتساق مـع الأهداف، والارتقاء بجودة التعليم.

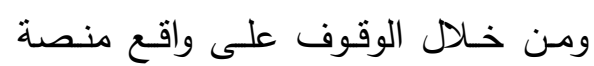

يوداسيتي كأعلى منصة حصلت على درجات

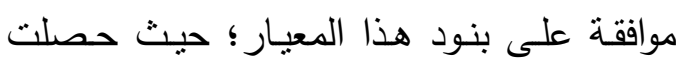

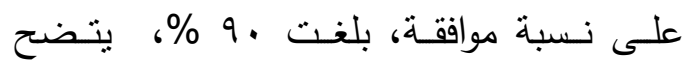
الاتساق بين النتائج السابقة وواقع المنصة، ومن لهن خلال الولوج إلى عينـة من المساقات المتاحة من خلالها، تبين أن المحتوى العلمي للمساقات

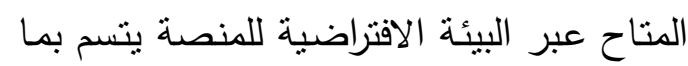
1- ارتباط المحتوى بالأهداف التعليمية للمساق.

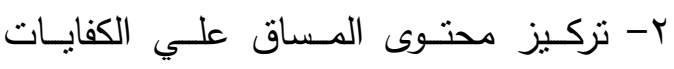
المعرفية والمهاريـة، والسلوكية المحددة التي يستهدفها المساق. 
العدد الرابع والخمسـون - 7 •

\section{Learner Interaction and ومشاركتهم}

:Engagement

توجد علاقة طردية بين التفاعل الإيجابي

والتحصيل العلمي وسلوك المتعلمين في بيئة موك، بينمـا هنـاك علاقة سـلبية بين التفاعل

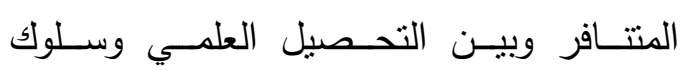
المتعلمين؛ حيث أنه يؤدي إلى انخفاض مستوى ولثي

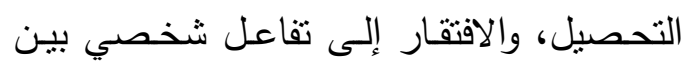
المتعلمين وهيئة التدريس بشكل فعال، إلى جانب

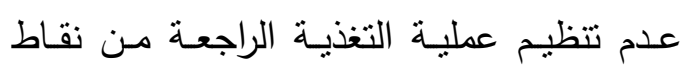
الضعف المحتملة والأساسية في التعلم عن بعد.

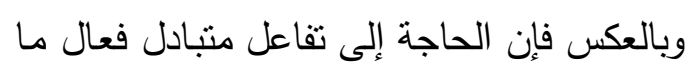

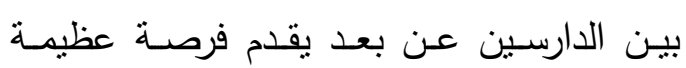

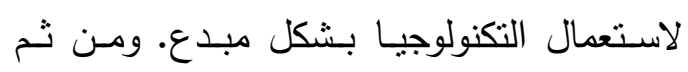
تتعلق التفاعليـة في بيئـة مـوك بمـدى توافـر
Network على عينـة مـن المتسربين مـن المسساقات

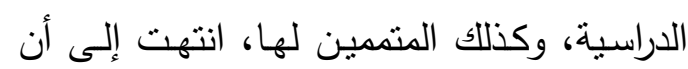

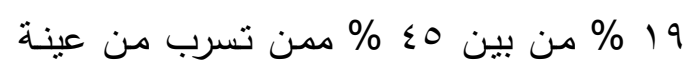

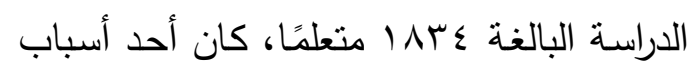

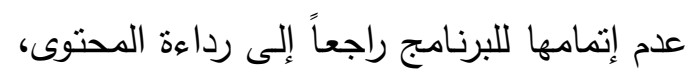

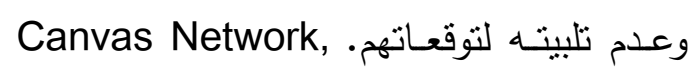
كما تم الانتهاء في الدراسة ذاتها إلى أن هب \%

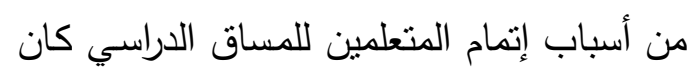
راجعًا لجـودة المحتوى التعليمسي. Canvas (Network, 2013)، فالدراسـة قاسـ في أحد جوانبها مزايا وسلبيات المساقات من وجهة نظر فلانة المتعلمين.

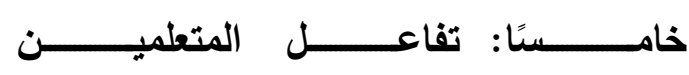

جدول رقم (9)

تفاعل المتعلمين ومشاركتهم (ؤ)

\begin{tabular}{|c|c|c|c|c|c|c|c|c|c|}
\hline \multicolumn{3}{|c|}{ كورسيرا } & \multicolumn{3}{|c|}{ إيدكس } & \multicolumn{3}{|c|}{ يوداسيتي } & \\
\hline موافيّ & محايد & موافق & موافِّير & محايد & موأفق & موافيّ & محايد & موافُق & \\
\hline$\% 0$ & $\% \Gamma$ & $\% 9 Y$ & $\% \mathrm{~V}$ & $\% r$ & $\% 91$ & $\% \Gamma$ & \%र & $\% 90$ & أهداف التعلم النشطنة التعلم \\
\hline$\% \mathrm{~V}$ & $\% Y$ & $\% 91$ & $\% 0$ & $\% \mathrm{~V}$ & $\% \wedge \wedge$ & $\% 7$ & $\% 0$ & $\% \wedge 9$ & 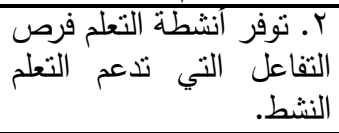 \\
\hline$\% r$ & $\% r$ & $\% 90$ & $\% 0$ & $\% r$ & $\% 94$ & $\% r$ & $\% r$ & $\% 97$ & 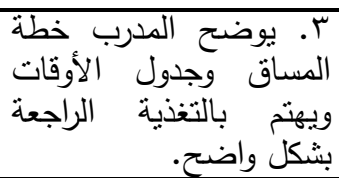 \\
\hline$\% 1$. & $\% \mathrm{~V}$ & 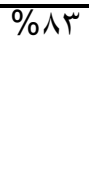 & $\% \mathrm{~V}$ & $\% \mathrm{~V}$ & $\% \wedge \uparrow$ & $\% 11$ & $\% r$ & $\% \wedge V$ & 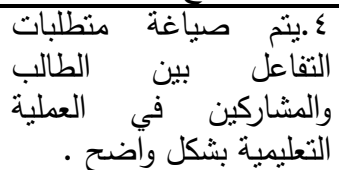 \\
\hline 0.0 & «.0 & $\% 9$. & $\% 4$ & $\varepsilon .0$ & $\% \wedge 9.0$ & $\% 0.0$ & $\%$ \%.० & $\% 94$ & المتوسط \\
\hline
\end{tabular}

101 
ومقاطع الفيديو، والمقالات ، وتكوين مجموعة دراسة Study Group في فيسبوك، أو من خـلال: جوجل هانقاونس.

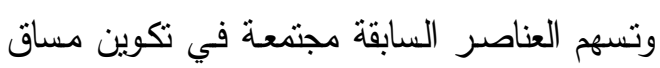
متكامل، متزابط، قائم على الثفاعل والمشاركة بين

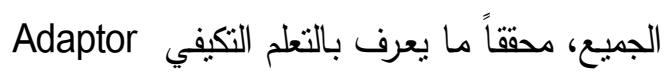
.Learning ع- توفير التفاعل المباشر من خلال هيئة التدريس

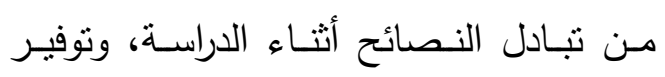
تعليمات مفصلة حول كل الدفاهيم أو عطليات

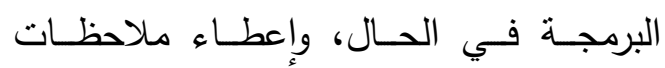

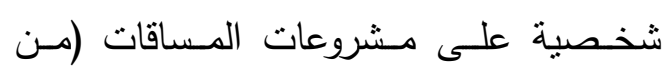
منطلق اهتمام المنصة بالمساقات المتخصصة في تكنولوجيا المعلومات بدرجة أكبر). ه- تزويد المساقات بوسيلة تفاعل أساسبة لتلقي

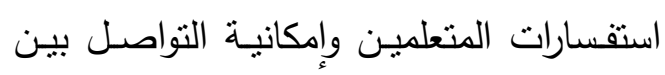

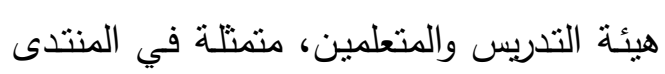
الذي تتبحه المنصة لكل مساق، الذي يوفر للمتعلم إمكانيـة التواصل مـع الزملاء وهيئة

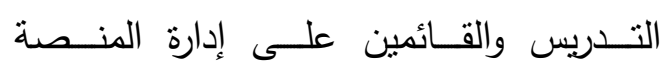
ومناقـشتهم في مختلـف القـضايا المتعلقـة الدانة بالدساق الدراسي،كما تتيح المنصة فنيات

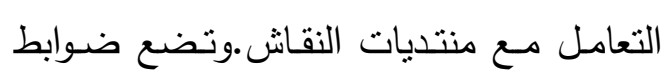
محددة لاستخدام المنتدى، كما يلي:

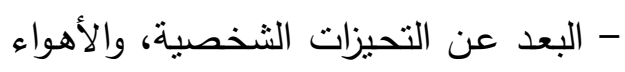

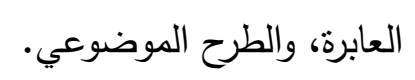

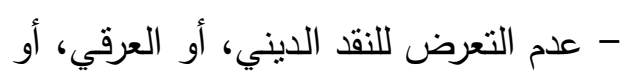

الأنشطة وتأثيرها، والإسهام في التعلم النشط، والتتوع، والاتساق مع أهداف المساق.

ومن خلال الوقوف على واقع منصة يوداسيتي

كأعلى منصة حصلت على درجات موافقة على بنود

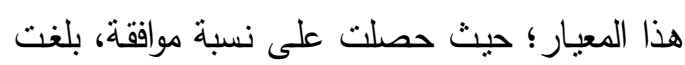

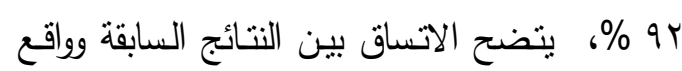
المنصة؛ حيث تدعم المنصة أنشطة النطلم، وكنا

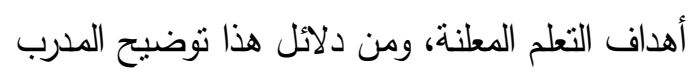

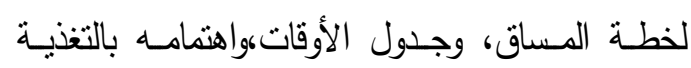

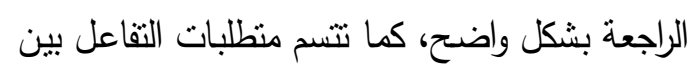
المتطلم والمشاركين في العطلية التعليمية بالوضسوح. وتثناز عناصر الثناعل المناحة في البيئة الافتراضية اللمنصة بما يلي: 1 - بداية المساق بعبارات ودية ترحب بالمتعلم

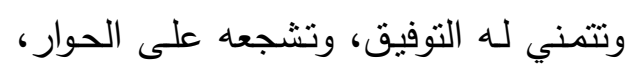

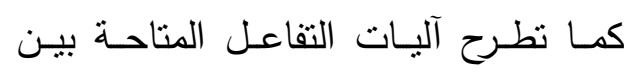

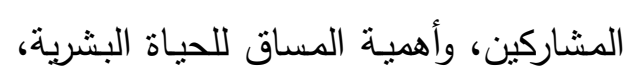
وتحدد الفئات المستهدفة من التدريس. r- وجود مخطط تدريس المساق، في صفحة البدء، يتكون من عدد الوحدات ومكوناتها وتوقيتاتها. r- إمكانية الاختيار بين أنماط مختلفة من التفاعل

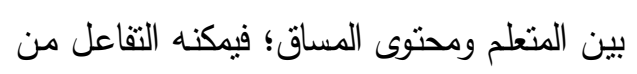

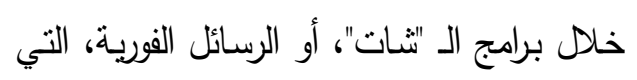

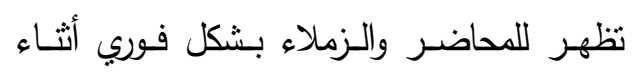

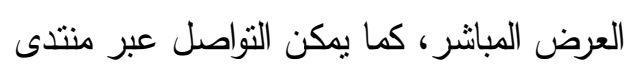

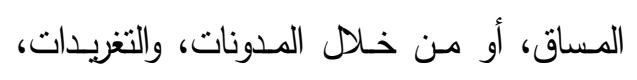


طسالبي العمل (بالإضـافة بـالطبع للحصول على المساق المحدد).

V- نتيح المنصة فرص عمل في مجالات ثلاثة أساسية، يمكن للمتعلم التسجيل فيها، هي:

$$
\text { - مطور ويب. }
$$

$$
\text { - مراجع جودة داخلي. }
$$

ᄉ- تقديم قائمسـة بأسـماء المتعلميـن وبريدهـــ

الإلكترونسي بمـا بساعد في التواصـل فيمـا بـاء

بينهم، من خـلال الآليات المختلفة، إضـافة

لتوافر الصفحات الثخصية (للتعلم وهيئة

التدريس)؛ حيث يمكن أن يكون للمشارك

صفحة شخصية يضع فيها صورته وما يشاء

مـن المعلومـات عـن نفسه (في حـدود

المسموح بـه في أعراف المنصة)، وبستطيع

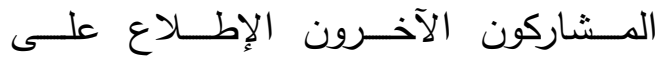
الصفحات الثخصية لبعضهم البعض.

9- الاتصال بالدعم الفني للمساعدة علي مدار

اسـتخدام المسساقات، مـن خـلال الآليـات

المساعدة، منل: التلميح النصي عند حدوث

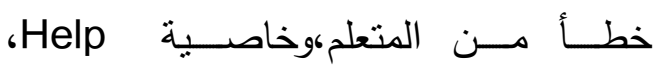

$$
\text { وصفحات المساعدة. }
$$

• ا- المساقات مـزودة بـأزرار تحكم، تعمـل

بالضغط مره واحدة على الزر، تمكن المتعلم

من التحكم في تسلسل عرض المحتوى.

ويؤكد على نجاح منصة يوداسيتي مـا

توصـل إليـه Terence Loose، مـن خـلال
الأيديولوجي، أو الجغرافي، أو اللغوي

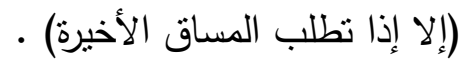

- أن تــم ردود الفعـل بالإيجابيـة، والبعد عن السخرية، والألفاظ النابية،

$$
\text { والهجوم الشخصي. }
$$

ويواجهـ المتعلمون الذين يخرجون عن

أعراف المنصة عقوبات يمكن أن تصل إلى إلغاء المساق.

7- إمكانيـة التواصـل مـع خبراء الـصناعة

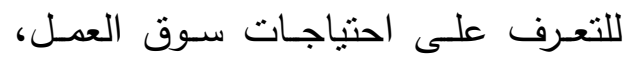

والفـرص المتاحـة.(وهـو موضـع شـكوى

منتسبي كورسيرا، الـذين يضصون عدم

توفير فرص عمل - بشكل جيد - من

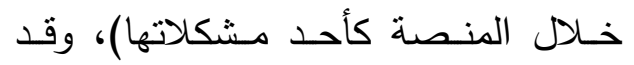

تميزت يوداسيتي في هذا الإطار؛ حيث

تعمل بشكل منسق مع الشركاء من رجال

الأعمال وخبراء الصناعة للتعرف على بلى ملى لهن

الوظـائف والمهارات التي يتطلبها سوق

العمل. كمـا أنها تتيـح قائمـة بالمؤسسات

المساعدة في توفير فرص العمل والمنح

الدراسية، ومن أهمها: AT\&T Aspire،

‘Genesys Works YearUp,

Boys \& Girls Clubs of

Communities In gamerica

Schools Jobs for America's

، Girls Who Code ،Graduates

كما تضع الثروط التي ينبغي توافرها في 
رغم الأهمية الثديدة لتكنولوجيا المعلومات، فلا ينبغي إغفال الهدف الأصيل من برامج موك، الأهيل

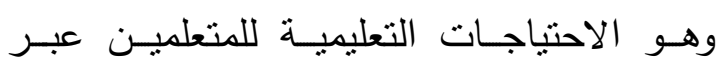
الإنترنت.

وتتعلق التكنولوجيا المستخدمة في برامـج

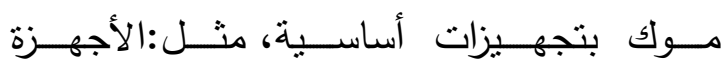

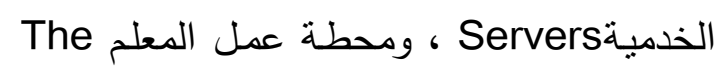
teacher's workstation المتعلـــــ The learner's workstation ، The internet access واستعمال الانترنت وتضم أجهزة الحاسب الآلي وشبكاته، ووسـائط متعددة من صوت وصورة، ورسومات، وآليات

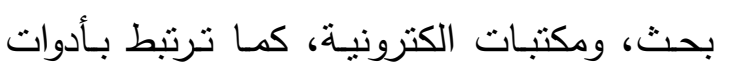
متتوعة من أثـهرها المحادثة Chat، والمؤتمرات الصوتية Audio Conferences، ومؤتمرات من وهوتهرات الفيديو Video Conferences، واللوح الأبيض White Boar E Satellite Programs

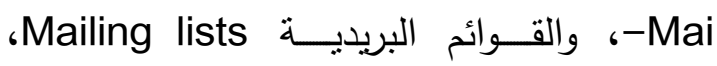
ومجموعـات النقـاش Discussion Groups ولت الن ونقــل الملفـات File Exchange، والفيديــو
دراسـة مسحية تم تطبيقها على عينـة مسن المتعلمين المتفوقين الذين اجتازوا مساقاتهم من المرة الأولى، وانتهى إلى أن أهم ما يميزهم تمنل فيما يلي:المن (Loose, Terence, 2014) - التواصل (مع الآخرين عبر الثبكة).

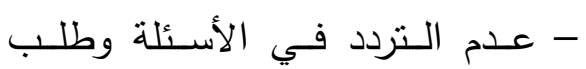

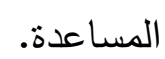

التواجـد علـى صــــات التواصـل

$$
\text { الاجتماعي. }
$$

ولتفاعـل المتعلميـن ومسشاركتهم دور

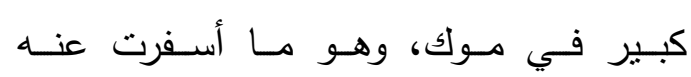

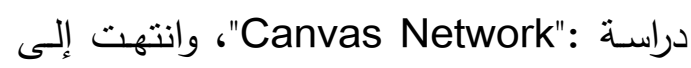

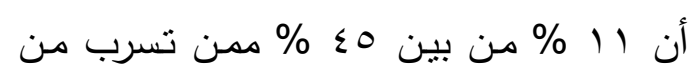

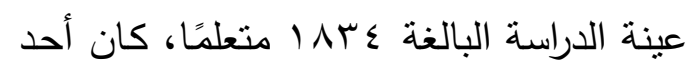

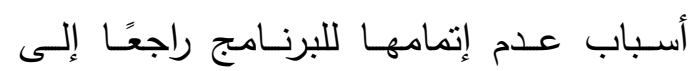

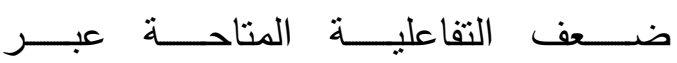
المنصات.(Canvas Network, 2013) وانتهت الدراسـة ذاتها إلى أن مدن اجتازوا برامج موك، كانوا من النشطين

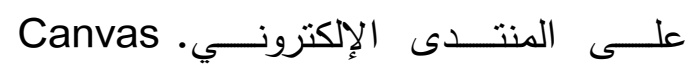
(Network, 2013)

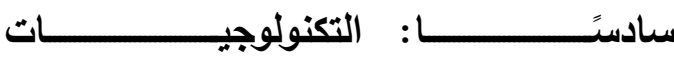
المستخدمة Course Technology تعتمـد بـرامج مـوك بشكل كلي على لـ

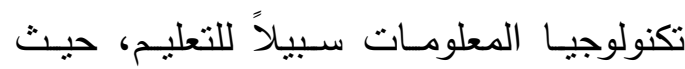
ساهمت هذه التكنولوجيا في انتشاره، وخفضت من تكلفته، وزادت من فاعليته. والحقيقة أنـه 
العدد الرابع والخمسون - 17 •

جدول رقم (· )

التكنولوجيا المستخدمة

\begin{tabular}{|c|c|c|c|c|c|c|c|c|c|}
\hline \multicolumn{3}{|c|}{ كورسيرا } & \multicolumn{3}{|c|}{ إيإكس } & \multicolumn{3}{|c|}{ يوداسيتي } & \multirow{2}{*}{ العبارات } \\
\hline موافِّي & محايد & موافق & موافيّن & محايد & موافق & موافيّر & محايد & موافق & \\
\hline$\% \varepsilon$ & $\% r$ & $\% 9 \varepsilon$ & $\% 0$ & $\% r$ & $\% 9 r$ & $\% 0$ & $\% \varepsilon$ & $\% 91$ & أهداف التنعلم. التقنية المستخدمة \\
\hline$\% \mathrm{~V}$ & $\% r$ & $\% 9$. & $\% \backslash 1$ & $\% r$ & $\% \wedge \mathrm{V}$ & $\% 0$ & $\% r$ & $\% 94$ & 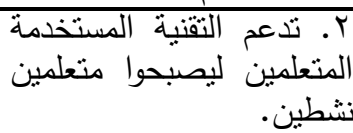 \\
\hline$\% \wedge$ & $\% 1$ & $\% 94$ & $\% \wedge$ & $\% 1$ & $\% 91$ & $\% \wedge$ & $\% r$ & $\% 9 r$ & البالفعالية (الدورة) على الإبحار في مكتونتات \\
\hline$\% \Gamma$ & $\% r$ & $\% 90$ & $\% 0$ & $\% r$ & $\% 94$ & $\% 0$ & $\% r$ & $\% 9 r$ & 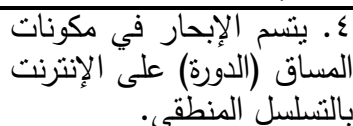 \\
\hline$\% r$ & $\% r$ & $\% 97$ & $\% r$ & $\% r$ & $\% 94$ & $\% r$ & $\% r$ & $\% 90$ & 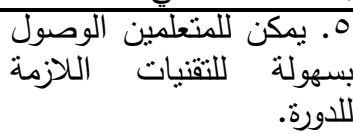 \\
\hline$\% \varepsilon$ & $\% r$ & $\% 9 \varepsilon$ & $\% \mathrm{~V}$ & $\% r$ & $\% 91$ & $\% 0$ & $\% r$ & $\% 94$ & 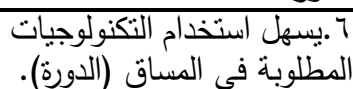 \\
\hline$\%$ \% . & $\% r$ & $\% 94.0$ & $\% \mathrm{~V}$ & $\% r$ & $\% 91$ & $\% \leqslant .0$ & $\%$ \%.o & \%वर & آلمتوسط \\
\hline
\end{tabular}

تكون إمكانيـات ذاكرة الوصـول العشوائي

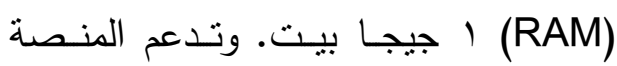

$$
\text { المتصفحات التالية: }
$$

(أحــــــ Chrome -

.Firefox $(r \mu+)-$

Safari $(7 .++)-$

.Internet Explorer $({ }+)-$

أمسا فيمـا بتعلـق بـأجززة المحمـول فـإن

تطبيقات المنصة متاحة حاليًا على أجهزة آي لي

فون ، وآي بـاد فئة (iOS 7)، وأندرويد فئة

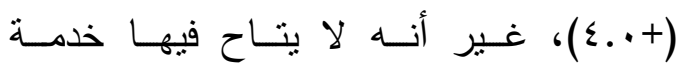

المنتديات، أو تقييم الأقران حتى الآن.
التفـاعلي Interactive Video، والأقـراص المدمجة CDs. - اعبة

ومـن خـلال الوقوف على واقع منصة

كورسبرا كأعلى منصة حصلت على درجات موافقة على بنود هذا المعيار ؛ حيث حصلت

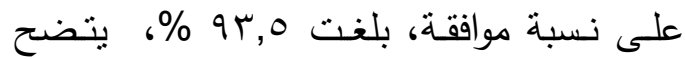

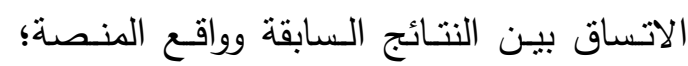
ويمكن الوقوف على هذا فيما يلي: 1- بساطة الاحتياجـات الماديـة مـن الأجهزة والمتصفحات، وسـهولة اسـتخدامها؛ فمـن منطلبـات المنصة،وسـيلة اتصال بـشبكة الإنترنت، يمكن الاعتمـاد عليها للوصـول إلـى الموقـع، وتحميـل المحاضـرات، وأن الإنـ 
ي- استخدم أسهم فهرس المحتويات وقوائم

الاختبار كارتباطات نشعبية.

r- تدعم التقنية المستخدمة أهداف التعلم، كما تدعم المتعلمين ليصبحوا متعلمين نشطين؛ ومن خلال الوقوف على واقع المنصة تبين التزامها بالمعايير الداخلية التالية: أ- معايير النصوص، حيث تتسم بـ: الوضوح، بـانيل

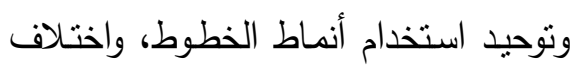
أبناط العناوين الرئيسة، وتباين لون خطوط

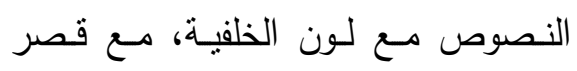

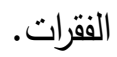

ب- تتسم الصور والرسوم بما يلي:

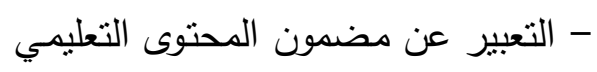

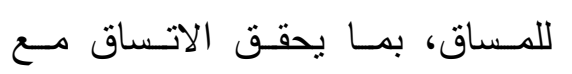
الأهداف. - البساطة والوضوح.

- تجنـب اسـتخدام الـصور المزدحمـة ولـوحة

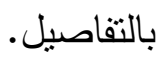
- مراعـاة التتاسـق والتوازن بيـن الصور والرسوم والنصوص. ج - نتسم مقاطع الفيديو بما يلي:

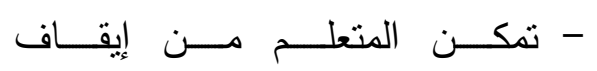

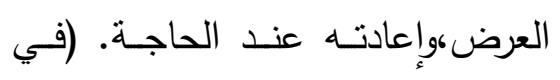
حال العرض غير المباشر ) - تجنب احتواء الثاشـة علي أكثر من مقطع. - التزامن بين الصوت ولقطة الفيديو -
كما يحتاج المتعلم كاميرا ويب مدمجة، وفي حال عدم توافرها يمكن استخدام كاميرا ويب

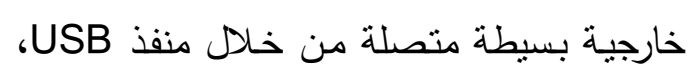

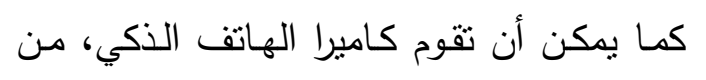
خلاد توصيلها بجهاز الكمبيوتر بالمهمة ذاتها،

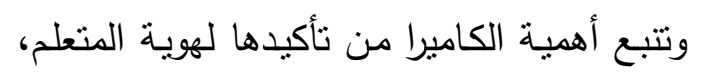

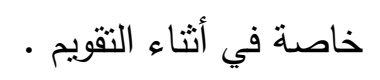
r- يتسم الإبحار في مكونات المساقات على لـ

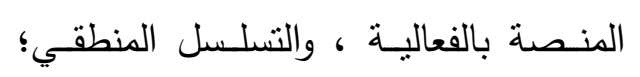
حيث تتسم المنصة بما يلي:

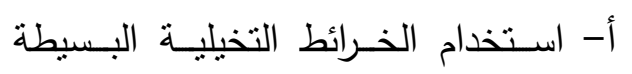

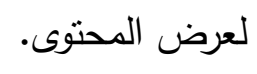
ب- ثبـات مواقـع أدوات التصفح داخـل صفحات المساق. ج - احتواء جميع الصفحات على زر الصنات العودة إلى الصفحة الرئيسية.

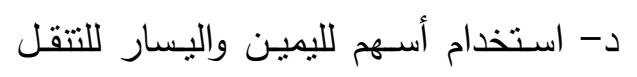
بين الصفحات. هـ- بساطة الأسلوب المستخدم للتتقل بين عناصر محتوى المساق. و - استخدام أدوات التصفح الرسومية. ز - بساطة أدوات التصفح المستخدمة. ح- تجمـع أزرار التصفح في شريط أفقي أسفل الثاشـة، يتم وضـع كافة الأزرار المستخدمة عليه.

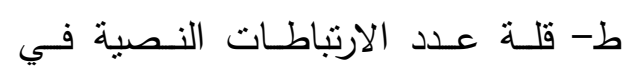
المقطع لضمان عدم التشتت. 
العدد الرابع والخمسـون - 7 •

- تجنب استخدام الصدى مع الصوت. - المؤثرات الصوتية طبيعية وقريبة قدر

$$
\text { الإمكان من الطبيعة. }
$$

هـ- كــا تتيـح المنصة الأدوات التقنيـة التالية التي تساعد على تحقق أهداف التعلم، وتساعد المتعلم ليكون نشطاً، وتتمنل هذه الأدوات فيما يلي:

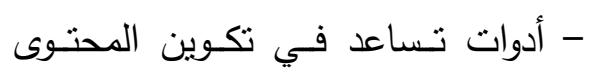

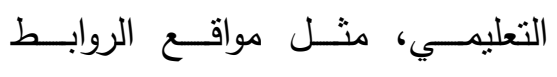
الاجتماعيـة، ومواقع الصور، ومواقـع

$$
\text { الفيديو والمدونات والويكي وغيرها. }
$$

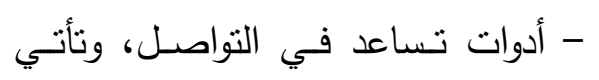
مكملة لوظيفة البربد الإكتروني مثل

(Twitter). خدمة تويتر - أدوات تشاعد في النتبيك الاجتماعي، تونزي، مثل موقع فيس بوك (Face book) وموقع ماي سبيس.(MySpace) - أدوات تسـاعد في فاعليـة الأدوات ماتي سن السابقة: مثنل استخدام خلاصـات

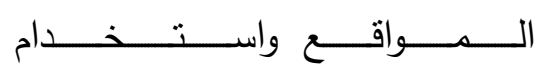
الوسوم (Tags) لتوصيف المصادر المختلفة.

وفي الحقيقة فإن للتكنولوجيا المستخدمة أثرًا جيدًا على جودة المنصات، بل وجودة الحياة بصفة عune Krumsvik عامة، وهو ما توصل جلئ إليه

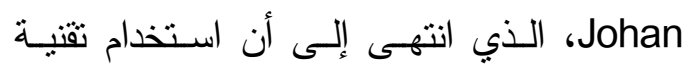
المعلومات والاتصالات يؤدي إلى حصول الطالب الب لن
- إمكانيـات نتزبـل محاضـرات الفيديو؛ حيث يمكن تحميل ملفات مضغوطة

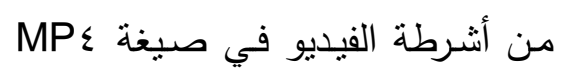
والنصوص في شكل SRT لجميع المساقات، وكذللك شـرائح العـروض التقديمية الخاصة بها. - إتاحة المحاضرات الخاصة بكل أسبوع مرة واحدة (غالبًا في بدايـة الأسبوع)، ويمكن للمتعلم تحميلها أو مشاهدتها في الوقت الذي يناسبه.

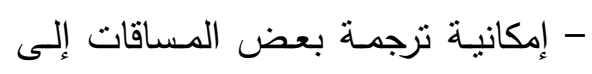
عدد من اللغات، إذا لم يكن المتعلم

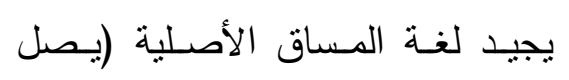

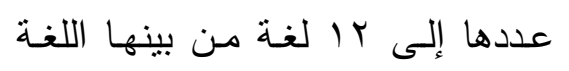

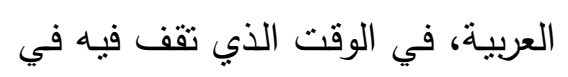
يوداسيتي عند خمس لغات).

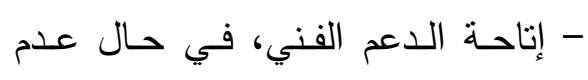

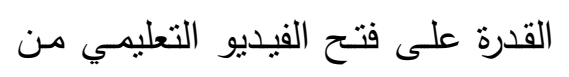

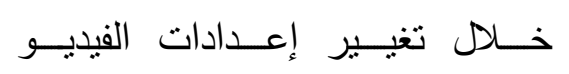

$$
\text { د - يتسم الصوت بما يلي: الافتراضي. }
$$

- تتاسبه مع الوظيفة المصاحب لها.

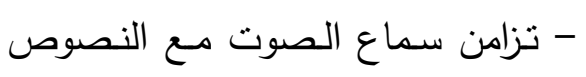

$$
\text { المكتوبة. }
$$

- قـدره المتعلم علـي إيقاف وضـبط

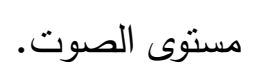


وضـوحها، مثـل توفيرهـا لــمجموعات دعـم

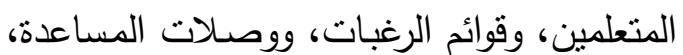
ومساعدة المتعلمين في حل المشكلات التقنية، وطرق التسجيل سـواء في المساقات أو في فعاليات المنصة المختلفة كالمنتديات والمؤتمرات الصوتية، ومؤتمـرات الفيديو، والقوائم البريديـة،

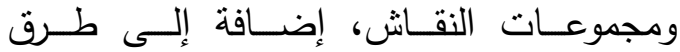
الاستخدام، والإضـافة والحذف، وكتابـة التقارير التهر وإمكانية التواصل مـع هيئة التدريس، سواء من
على فـرص أعلى ليعيش حالـة مـن الرخـاء والاستقرار المـادي، نتيجة لكون هذا النـوع مـن التعليم يثجع على التخرج، وبالتالي زيادة الخيارات الوظيفيـة وعدم الانزلاق في بيئة تولد المشناكل الاجتماعية في وقت لاحق. Krumsvik, Rune) Johan, 2012)

\section{سابعًا: دعم المتعلم Learner Support :} تتعلـق عمليـات دعـم المتعلـم بتوفيـر المنـصات للـدعم الفـني واللوجيـستي ومـدى

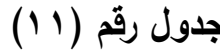

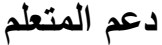

\begin{tabular}{|c|c|c|c|c|c|c|c|c|c|}
\hline \multicolumn{3}{|c|}{ كورسيرا } & \multicolumn{3}{|c|}{ إيدكس } & \multicolumn{3}{|c|}{ يوداسيتي } & \\
\hline موافير & محايد & موافق & موافير & محايد & موافق & موافيق & محايذ & موافق & \\
\hline$\% 4$ & $\% r$ & $\% 94$ & $\% V$ & $\% r$ & $\% 91$ & $\% r$ & $\% r$ & $\% 9 \leq$ & 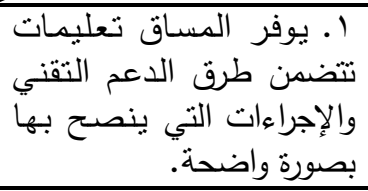 \\
\hline$\% 7$ & $\% 1$ & $\% 94$ & $\% r$ & $\% r$ & $\% q \varepsilon$ & $\% \varepsilon$ & $\% r$ & $\% 94$ & 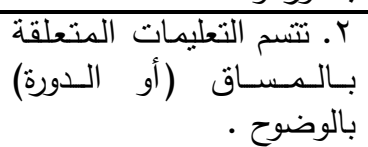 \\
\hline$\% r$ & $\% r$ & $\% 9 \xi$ & $\% r$ & $\% 0$ & $\% q 4$ & $\% \mathrm{~V}$ & $\% r$ & $\% 91$ & بالوباسات وخدمات التعليمات المتسعلقة \\
\hline$\% 0$ & $\% r$ & $\% 94$ & $\% 1$. & $\% 0$ & $\% \wedge \diamond$ & $\% 1$. & $\% Y$ & $\% \wedge \wedge$ & 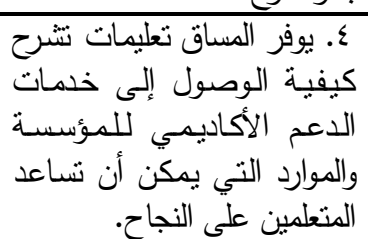 \\
\hline$\% 0$ & $\% r$ & $\%$ \%व & $\% \mathrm{~V}$ & $\%$ \%.० & $\% 9 \cdot .0$ & $\% 4.0$ & $\% r$ & $\% 91.0$ & المتوسط \\
\hline
\end{tabular}

كورسيرا، يتضح الاتساق بين النتائج السابقة خلا بربدهم الإلكتروني، أو من خلال برامج الـ وواقع المنصة؛ فقد حصلت على نسبة موافقة،

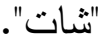
ومن خـلال الوقوف على واقع منصة بلغت به \%، عيث توفر المنصة تعليمات 
العدد الرابع والخمسـون - 7 •

$$
\text { البريد الإكتروني. }
$$

- Help إناحة خاصبة الإنروبه -

- برنـامج التغذيـة المرتـدة. back program

- مسساعدو التدريس المـشترك(TAs)

Community Teaching

Assistants

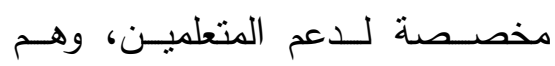

متعلمـون سـابقون حاصـلون علـى

المساق نفسه من قبل، تكمن مهمتهم

في تقديم الدعم المستمر للمتعلمين،

على المستوبين التعليمي والتقني.

- إمكانيـة ترجمـة بعض المساقات إلى

عدد من اللغات، إذا لـم يكن المتعلم

يجيـ لغـة المساق الأصلية (يـصل ليكل

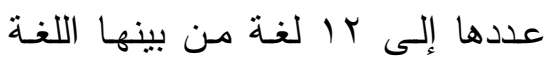

العربية، في الوقت الذي تقف فيه في

يوداسيتي عند خمس لغات).

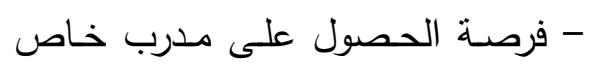

(يقـوم بـدور المـدرس الخصوصـي ملهي

( بمقابـل مـادي)، مـن خــل بل برنامـج

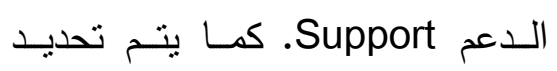

مواعيد العمل، والساعات الأسبوعية

المخصصة للمتعلم (• (1 ساعات).

كما تتميز تعليمات الدعم الفني بالوضوح،

وعلى سبيل المثنال فهي تعطي تعليمات واضـحة

حول: الاحتياجـات الماديـة المطلوبـة مـن الأجهزة
تتضمن طرق الدعم التقني والإجراءات التي ينصح بها بصورة واضـحة. وتتسم التعليمـات

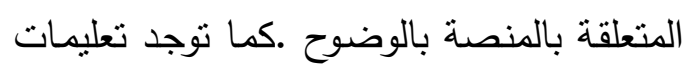
تشرح كيفية الوصول لخدمات الدعم الأكاديمي. وتتمثل أهم عناصر دعم المتعلم التي نتيحها المنصة فيما يلي: المن المن

1- الـدعم الفـني، واللوجيـستي مـن خــل

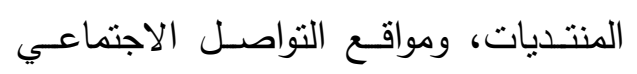

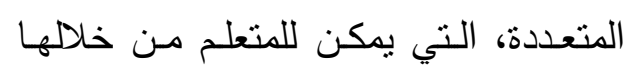

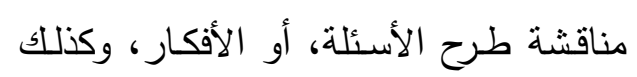

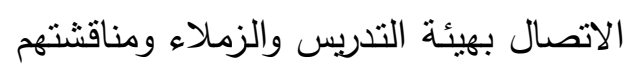

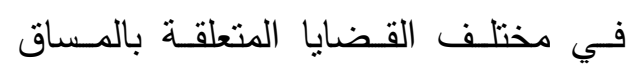
الدراسي. ץ- الإجابة على الاستقسارات بشكل فوري من خلا: أ. توافـر خاصـية الإجابـة على أسـئلة المتعلم حول المساق. ب. بفحات المساعدة. ج. استمرارية عمليات التوجيه والمساعدة في جميع الصفحات.

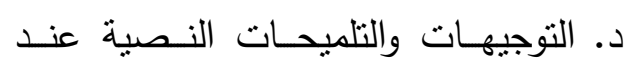
حدوث خطأ من المتعلم. هـ. توضيح ماهية الخطأ وسبب حدوثه وما يمكن أن يفعله المتعلم عند حدوث الخطأ.

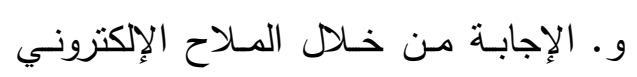

.Cyber navigator ز. وفي حال تعذر ذلك يتم الإجابة عبر 
تعتبر قضية إمكانية الوصول من الأمور المهمة جدًا بالنسبة لمنصات موك، وتتعلق هذه

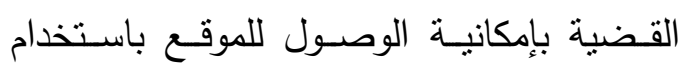

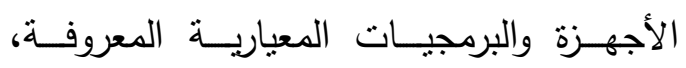

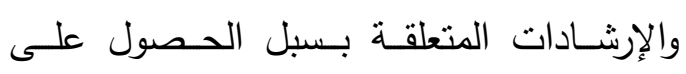
التكنولوجيا المستخدمة، وطرق الحصول عليها، ومـدى احتياجها إلى بيئـة خاصـة، وإمكانيـة

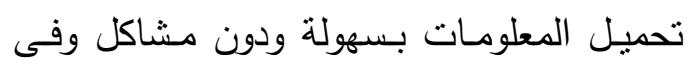
وقت معقول، ووضوح الأيقونات، ومدى احتواء المساق على الفهارس المساعدة، ومحركـات البحث، وسـهولة تصميم المساق، واستنيعابه للتكنولوجيا الدساعدة، وجودة الروابط البينيـة،
والمتصفحات، وامكانيات ذاكرة الوصول العشوائي، وتقديم إرشادات وتعليمات واضحة نساعد المتعلم

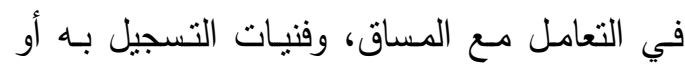

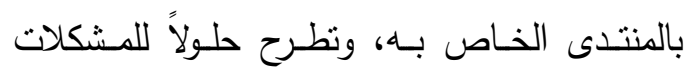

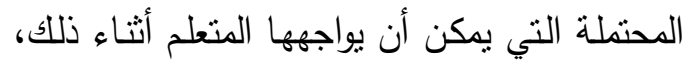
مثل تغيير عنوان بريده الإلكتروني، وعدم عمل الفهل

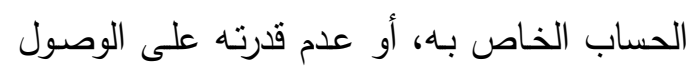
إلى حسابه، وكيفية إيقاف أو بدء استثبال رسائل البّل البريد الإلكتروني، وسبل تغيير إعدادات الحساب

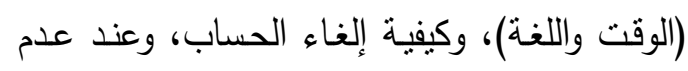
القدرة على فتح الفيديو التعليمي. ثامنًا: إمكانية الوصول Accessibility :

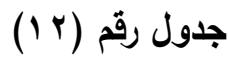

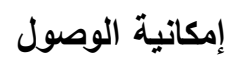

\begin{tabular}{|c|c|c|c|c|c|c|c|c|c|}
\hline \multicolumn{3}{|c|}{ كورسيرا } & \multicolumn{3}{|c|}{ إيدكس } & \multicolumn{3}{|c|}{ يوداسيتي } & \multirow{2}{*}{ العبارات } \\
\hline موافيز & محايد & موافق & غوافير & محايد & موافق & موافق & محايد & موافق & \\
\hline$\% r$ & $\% \varepsilon$ & $\% 9\{$ & $\% 0$ & $\% \varepsilon$ & $\% 91$ & $\% r$ & $\% 0$ & $\% q 4$ & 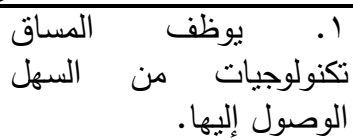 \\
\hline$\% r$ & $\% 0$ & $\% q r$ & $\% r$ & $\% \mathrm{~V}$ & $\% 91$ & $\% 1$ & $\% 4$ & $\% 94$ & حول يقدم كيفية المساق إرشادات \\
\hline$\% \varepsilon$ & $\% 1$ & $\% 90$ & $\% r$ & $\% \wedge$ & $\% 9$. & $\% r$ & $\% \vee$ & $\% 91$ & 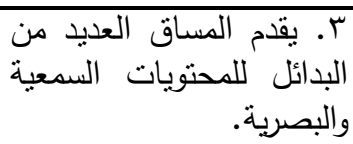 \\
\hline$\% r$ & $\% r$ & $\% 9\{$ & $\% 0$ & $\% \wedge$ & $\% \wedge \vee$ & $\% 0$ & $\% \varepsilon$ & $\% 91$ & القراءة ويقلال تصنيم الانحرافات. \\
\hline$\% 1$ & $\% 7$ & $\% 94$ & $\% 1$ & $\% 11$ & $\% \wedge \wedge$ & $\% r$ & $\% r$ & $\% 9 \varepsilon$ & 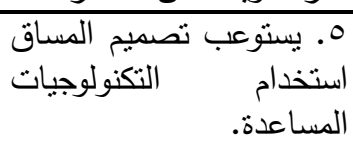 \\
\hline$\% r$ & $\% \varepsilon$ & $\% 9\{$ & $\% r$ & $\% \wedge$ & $\% \wedge q$ & $\%$ & $\% 0$ & $\% q 4$ & المتوسط \\
\hline
\end{tabular}


العدد الرابع والخمسـون - 7 •

البيئة الافتراضية للمنصة بما يلي:

1 - وضوح وظائف الأيقونات والأزرار - وليه

r- تتـاول المسساق لقائمسة محتوبـات تفـصيلية مسشتملة علـى الأهـداف والمخرجات التعليمية.

r- ربط كل صـفحة بسابقتها وببدايـة الوحدة وبداية المساق.

ع- ربط أجـزاء المسساق مسع بعـضهاف البعض بروابط.

ه- إمكانيـة التعامل مـع المساقات على بـى

$$
\text { مدار الساعة. - مدانه }
$$

צ- وجود فهرس لعرض الموضوعات.

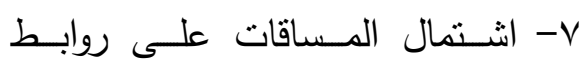

$$
\text { لمصادر تعلم مناسبة. }
$$

1- تقديم رابط خاص لموقع المؤسسة

التعليمية التي قامت بنشر المقرر .

9- إمكانيـة استخدام الصور كروابط أو

وصلات.

ومـن خـلال اسـتعراض النتائج السـابقة

يتضح جليًا التقارب الثديد في النتائج الإجمالية
ومحـددات المـرور للمسـاقات، مثـل كلمـات المرور ، والمتطلبات الأخرى للشبكة.

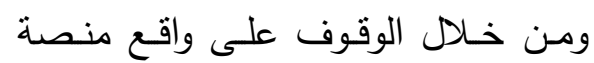

كورسيرا كأعلى منصة حصلت على درجات

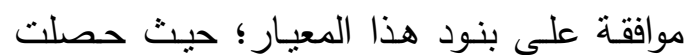

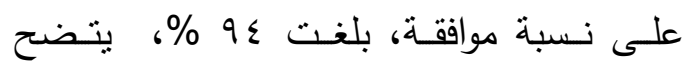
الاتساق بيـن النتائج السابقة وواقع المنصة؛ حيث تتعدد أسـاليب وأدوات الوصسول والإبحسار في البيئة الافتراضـية للمنصة، فهي تستخدم

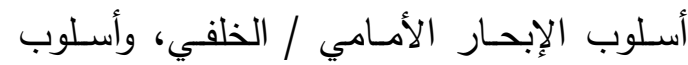

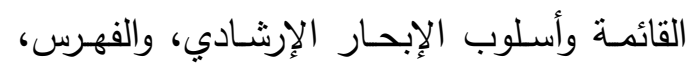

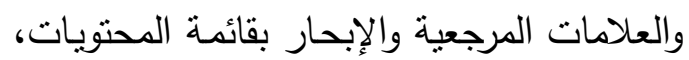

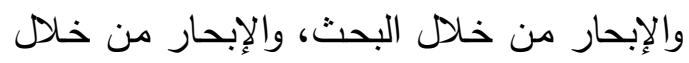

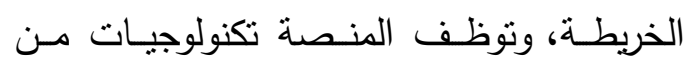
السهل الوصـول إليها، واسـتخدامها سـواء مـن ونـ

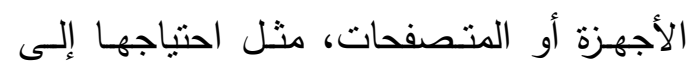
متصفحات: جوجل كروم (أحدث إصدار)، أو الأن

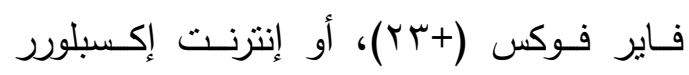

وتمتـاز إمكانيـات الوصـول التي توفرهـا

جدول رقم (r)

\begin{tabular}{|c|c|c|c|c|c|c|c|c|}
\hline \multicolumn{3}{|c|}{ كورسيرا } & \multicolumn{3}{|c|}{ إيدكس } & \multicolumn{3}{|c|}{ يوداسيتي } \\
\hline غير موافق & محايد & موافق & غير موافق & محايد & موافق & غير موافق & محايد & موافق \\
\hline$\%$ \%५.人 & $\%$ \%.० & $\% 91 . V$ & $\% 0 . r$ & $\%$ \%.० & $9 . . r$ & $\%$ \% & \%气.V & $\% 91 . r$ \\
\hline
\end{tabular}

النتائج الإجمالية للمنصات الثلاث 
العاجية للأوساط الأكاديمية. ويري "دوج بيكر“،

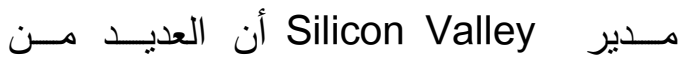
الجامعات ستضطر - راغبة أو رغماً عنها - لهنائ أن تتماثـي مـع هذا التعليم، وأن تقدم اعتمـاداً لمقرراتها، وأن تنح شهادات لأولئك الذين أكلوا

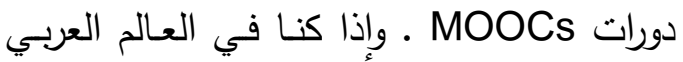
رغم الرزايا الجمة لبرامج MOOCs ، قد تأخرنا عن الركب الدولي، ولم تنوافر لدينا منصة موك متخصصة في مجال التعليم العالي حتى الآن، فقد آن لنا أن نأخذ بزمام المبادرة، وعلينا أن

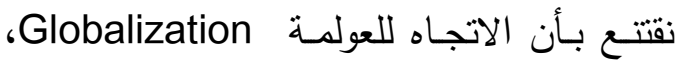

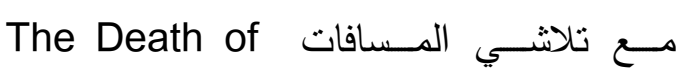
Distances وتقلصها بـات اتجاهـاً حتميـاً فرضـته ظـروف التطور وطبيعته، ولا يمكن مقاومته أو تغييره، ولكن يمكن الاستعداد لـه

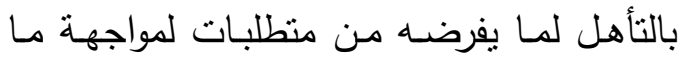
يفرضده- أيضًا - من تحديات بكفاءة. ومن ثم فسيتم - فيما يلي - طرح تصور لهنصة موك

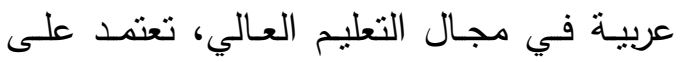
مرحلتين للتطوير، هما:

المرحلة الأولى: التخطيط القبلي، ويتتاول حاجـة الـسوق والمستيتفيدين، والمنطلبـات، ومحددات ينبغي تتفيذها قبل البدء. المرحلة الثانية: محاور التتفيذ.

r / / / / المرحلة الأولى: التخطيط القبلي: قبل البدء في اعتماد المساقات المفتوحة واسـة النطـاق عبر الإنترنت (MOOCs)،
للدراسـة بيـن المنصات الثلاث، وذلك طبقاً لإلجدول رقم (r) (1).

حيث بلغت نسبة الموافقة في منصة كورسيرا النسبة الأعلى بمتوسط V.

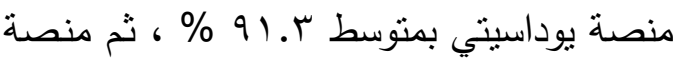
إيدكس، بمتوسط r..9 \%، مع ارتفاع درجات الموافقة بصفة عامة، ووجود نوافق بين النتائج وواقع المنصات، هذا إضـافة لتفـاوت تميز المنصات الداخلي في المعايير ؛ حيث تتفوق كورسـيرا فـي معسايير: مقدمسـة الدسساق

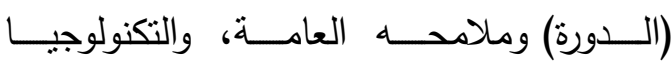
المستخدمة، ودعم المتعلم، وإمكانية الوصول، في الوقت الذي تتفوق فيه يوداسيتي في معايير :

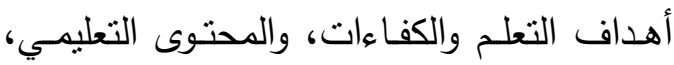

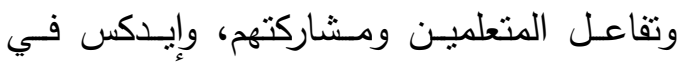

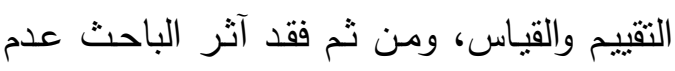
تحديد منصة واحدة لاتخاذها مثالاً، ونموذجًا يحتذى بـه، ولكن بمكن الأخذ من المنصات

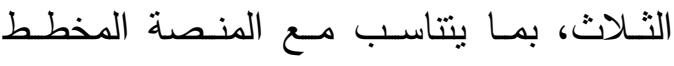
لإنشائها.

r / التصور المقترح لمنصة موك عربيـة متخصصة في مجال التعليم العالي: يشير النطور السريع واعتماد المساقات

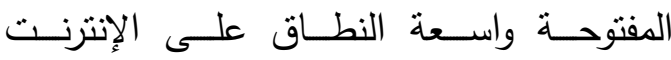
إلى تحول جوهري في استراتيجيات (MOOCs) التعليم العالي، حنى اعتقد الكثيرون أن هذا النوع من التعليم MOOCs بدأ يهدد الأبراج 
سيعود بالفائدة على الجامعات، يضاف إلى هذا

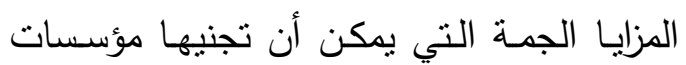
التعليم العالي من فوائد موك .

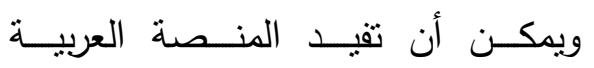
المستهدف إنشاؤها الفئات التالية: - جميع الناطقين باللغـة العربيـة، أبًا كان تواجدهم. - جميع الأفراد الذين برغبون في تعلم مساق

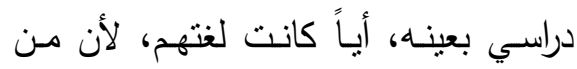
المخطط وجـود ترجمـة للمساق بلغـات أخرى، غير العربية، من خلال مجموعات الـدعم (وهــم متعلمـون سـابقون درسـوا المساق، يجيـدون العربيـة رغم أن لغتهم

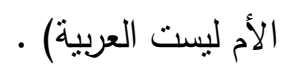

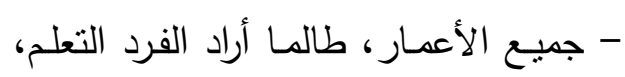
وإن كان مـن الأفضل أن تكـون بدايـة النة العمر من سا عامًا (شأن ما هو مطبق بالمنصات الدولية). أياً كانت دولهم، أو أو لغتهم، أو أمـاكن تواجدهم، أو خلفياتهم العلمية. فقط من يرغب في التعليم. ولا يشترط وجود سابق خبرة لدى المتعلمين في المساقات، باستثناء بعضها.

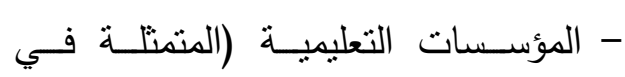
الجامعـات والكليـات والمعاهد الخاصـة والحكومية المحلية والإقليمية). - أعـضـاء هيئـات التـدريس والهيئـات والهيهات المعاونــة بالمؤسـسات التعليميـة سـابق
ينبغي للمؤسسات أن تسعى إلى الوقوف على مدى حاجة السوق العربي، وما إذا كانت ستحل مشكلة حقيقية، كما ينبخي فهم أكبر عدد ممكن من نواحي الخطر المحتملة. إضافة إلى الوقوف على حقوق ومسئوليات جميع الأطراف المعنية، ووضع الاستراتيجيات والسياسات الخاصـة بنظام MOOCs والتأكد من أن جميع أعضاء هيئة التدريس المشاركين على استعداد للمشاركة في عملية التتفيذ. ويمكن استتعراض أهم المحساور التي ينبغي مراعاتها عند تصميم منصة عربية فيما بلي:

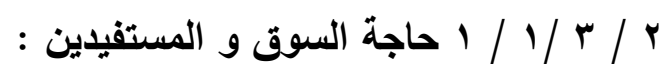
في الوقت الذي تتوافر فيه عدة منصات

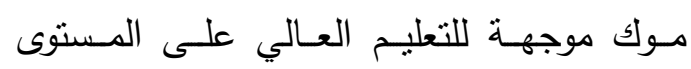
الدولي، لا تتوافر منصة عربية لها الهدف نفسه، مُهـ

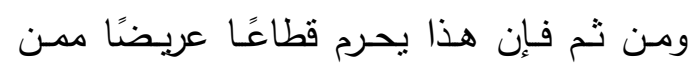
يرغبون في التعليم العالي من العرب ممن لا لاعن لاعن يجيدون التعامل مع اللغات الأجنبية (الإنجليزية

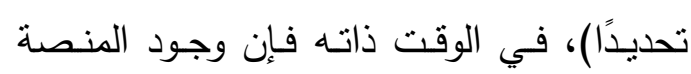
العربية سيفتح آفاقًا واسعة أمام مؤسسات التعليم العالي العربية، لنطوير ذاتها، وخوض تجارب جديدة في مجال التعلم عن بعد، في ظل ما تحياه من مشكلات التمويل، إضافة لعدم الحاجة لتواجد المتعلمين فيزيقيًا بمؤسسة التعليم، ومن ثم ثن

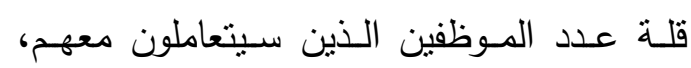
وإطالـة العمر الافتراضـي لتجهيزات الجامعات ومبانيها، وسيسهم هذا في مـردود اقتصادي 
(The internet استعمال الانترنت .access )

وتضم أجهزة الحاسب الآلي وشبكاته - منودة

وسائط متعددة من صوت وصورة رسومات - آليات بحث مندة - مكتبات إلكترونية، وافتراضية.

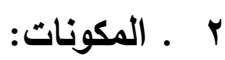

- مواد تعليمية حديثة ومستمرة التحديث. - التفاعـل النشط بيـن أطـراف العمليـة التعليمبة. - تقبل هذه الطريقة. - توافرهـا فـي أوقـات متعـددة لتتاسـبـ المتعلمين بظروفهم المنتوعة. - تسهيل عملية استخدامها للمتعلمين. - احتماليـة التطويـر وفــف مــا تمليـهـ التطورات.

- الاشتـراك والتعـاون مـن كافـة الأطـراف حـتى يتـسنى الاسـتفادة مسن خـبرات

$$
\text { الآخرين. }
$$

r. البيئة التعليمية:

تتكون البيئة التعليميـة لبرامج موك من الآتي:

أ - هيئة التدريس. ونتطلب توافر الخصائص

$$
\text { التالية: - هيته }
$$

- القدرة علي التدريس من خلال استخدام

$$
\text { تقنيات التعليم الحديثة. }
$$

- التعاطي الجيد مع استخدام الحاسب الآلي،
الإشتارة إليها.

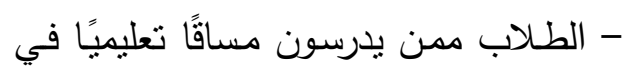
جامعة تقليدية، ويودون زيادة معلوماتهم؛ حيث سيزيد هذا من كفاءتهم، مما يسهر

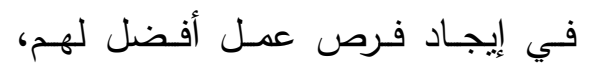
خاصة وأن المنصات تأخذ على عاتقها الآن تسويث المتعلميـن لـدى أصـحاب الأعمال، وكذا عقد لقاءات بين رجال الأعمال والمتعلمين. - المنظمات والهيئات العامة والخاصة التئي

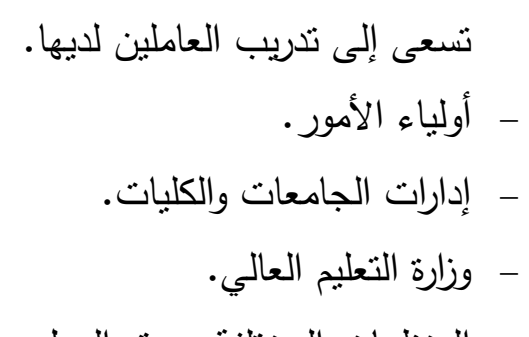
- - المنظمات المختلفة بسوق العمل. - - الجهات الحكومية المختلفة. - المجنمع بوجه عام.

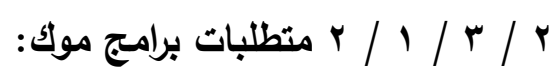
ا - التجهيزات الأساسية :

هناك مجموعة من التجهيزات التي ينبغي توافرها عند تتفيذ برامج موك، تتمنل فيما - الأجهزة الخدمية ( Servers) - محطة عمل المعلم (The teacher's .workstation )

- محطة عمل المتعلم (The learner's .workstation ) 
العدد الرابع والخمسـون - 7 •

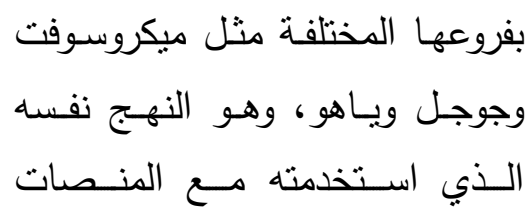

الدوليــة، وأثــــرها Coursera

و dacity، و و EDX وأكاديمية خان.

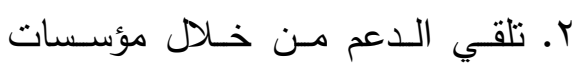

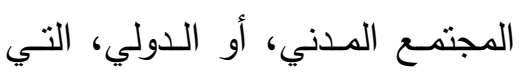

تضع خدمـة التعليم والبحث العلمي

أحد أهدافها، شريطة ألا يكون لها

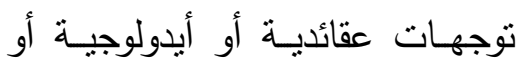

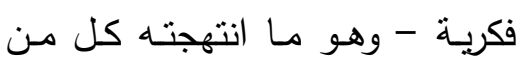

منـصات: كورسـيرا وإيـدكس عنـد

إنشائهما - ومن أفضل النماذج التي

تقوم على هذا الأمر في مصر هي:

- مؤسسة مصر الخير (ولها سبق في هوم هي هي

تمويـل بعض المشروعات البحثيـة

بجامعة بني سـويف، ومنحها وقفًا

بحثيًا للجامعة بقيمة مليون جنيه).

$$
\text { - مؤسسة نهضة بني سويف. }
$$

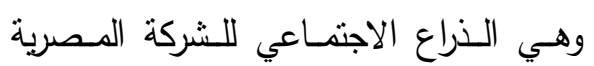

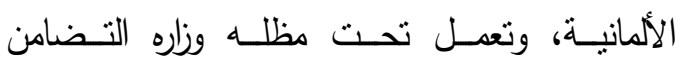

الاجتماعي، وهي مؤسسة تتموية خيرية لا تهدف إلى ونى

الربح، يقع نطاق عملها داخل محافظة بني سويف.

جهودها السابقة في دعم جامعة بني سويف:

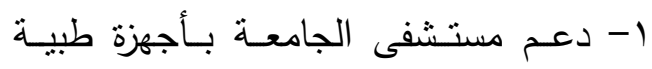

$$
\text { بإجمالي مبلغ ع ملايين جنيه. }
$$

r- إنشاء وتجهيز والإشراف على مركز التعلم

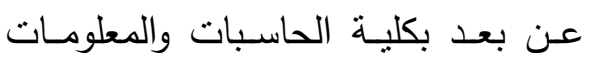

والثقنيات الحديثة المساعدة في التعلم عبر

الإنتزنت.

ب. المتعلـــ. ويتطلـب توافـر الخـصائص

التالية:

- مهارة التعلم الذاتي Self directed learning skills )

- معرفة جيدة باستخدام الحاسب الآلي

وشبكة الإنترنت.

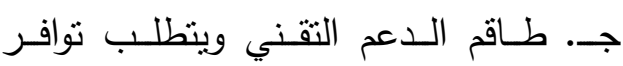
الخصائص التالية:

- التخصص بطبيعة الحال في الحاسب

$$
\text { الآلي ومكونات الإنترنت. }
$$

- معرفة بعض برامج الحاسب الآلي ذات

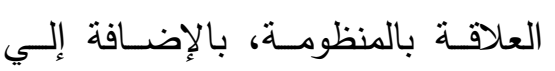

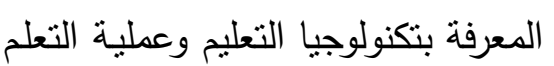

$$
\text { د. د. الطاقم الفني المركزي. }
$$

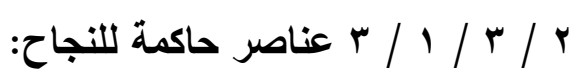

تتثثل أهـم العناصـر الحاكمـة لنجـاح

المنصة المستهدفة فيما يلي:

1- البحث عن مصادر للتمويـل، ويمكن أن يعتمد تمويل المنصة على ما يلي:

ا. تلقي الدعم، من خله : تعليل

ا ـ الدعم المباشر من خـال المؤس المونسات

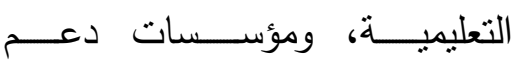

المـشروعات التكنولوجيــة ورجـال

الأعمــال، وشــركات التكنولوجيــا 
والثقافيـة ...الـخ والملـصقات الجداريـة، والكتيـات، والمؤتمـرات، والاجتماعـات، ولتهات والنـدوات الدوريـة، والاتـصال بوسـائل ولئل الإعـلام العامسة بـشتى صـورها بهدف ولته التعريف بها وأنشطتها المختلفة. - المكان Place أو التوزيع Plistribution وهو البيئة الإكترونيـة التي تقدم فيها ومن خلالها المساقات بمختلف إمكانياتها وتجهيزاتها.

ب. التسويق الإكتروني للمنصة، من خـل تطبيق مجموعـة مـن القوانين والمعايير الأساسـية، التي تجعل المحتوى أكثر جذبًا، وتساعد في إحداث رواج نوعي له. أكثر جاذبية.

ب- طـرح تصور متكامـل لخطـة اسـتراتيجية للمنصة، تشمل روئة المنصة، ورسـالتها،

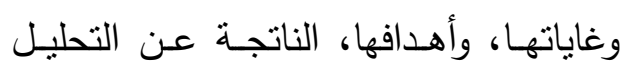
البيئي لها (SWOT Analysis) ، إضـافة وفئة

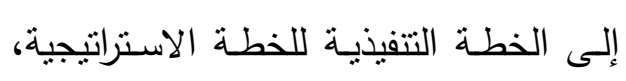

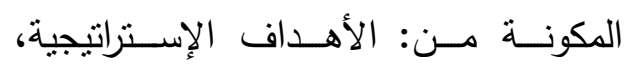

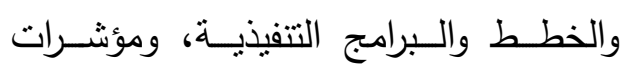

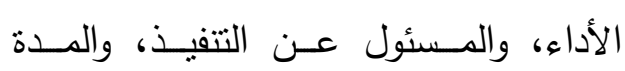

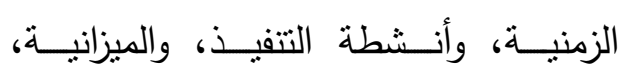

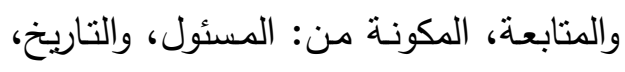
والمؤشرات.

MOOCs / / / / محددات للبدء في :(Wessel, Madelyn, 9 / 11 / 2013) ينبخي على المؤسسة مراعاة ما يلي قبل

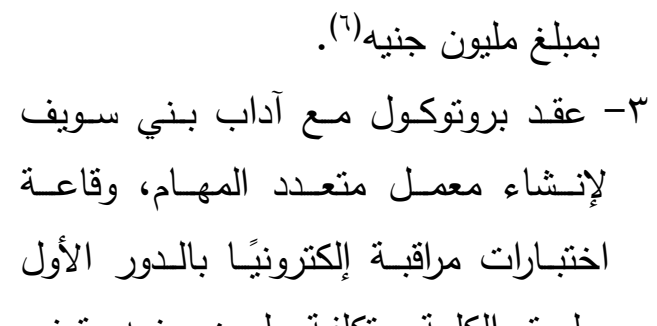

بملحق الكلية، بتكلفة مليون جنيه، تمنح

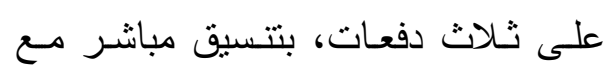
الباحث. ب. الأرباح المباشرة (وإن كانت رمزبة)

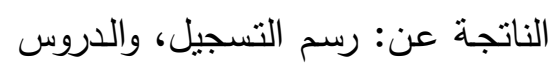

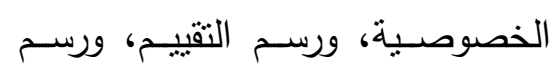

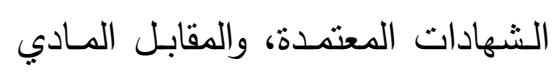

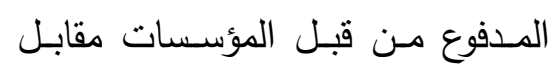
الـدورات المخصسصة للعـاملين بهـا، وتوظيــف الخـريجين، والإعلانــات

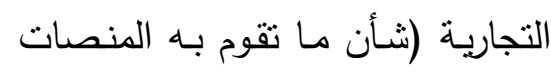
الدولية قيد البحث).

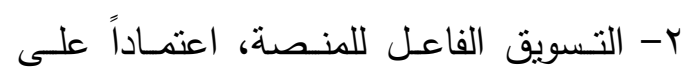
الاستراتيجيات التسويقية على الصعيدين: أ. التقليدي، الذي يعتمد على جودة كل من :

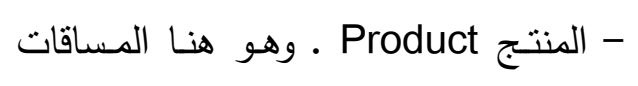
الدراسية المقدمة عبر الإنترنت.

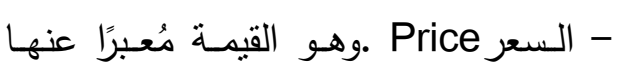
بوحدات نقدية، وهو أي رسم مدفوع مقابل

$$
\text { الحصول على المساقات. }
$$

- الترويج Promotion . وهو عل السياسـات

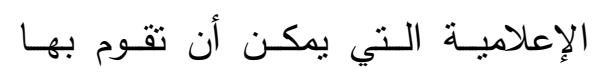

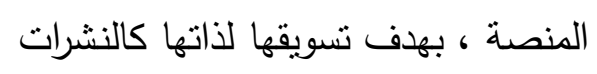
الإعلامية وأنشطتها الاجتماعية والعلمية كنية 
العدد الرابع والخمسـون - 7 •

المساقات الطويلــة إلـى عـدة آلاف مسن الدولارات.

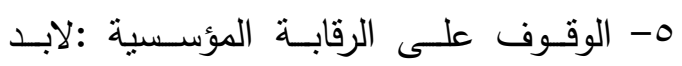

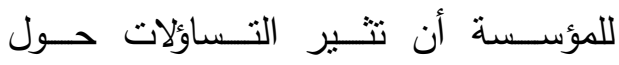
الأشخاص الذين سيقومون بتشغيل مبادرة MOOCs الـضوابط المؤسسية وعلىى أي مستوى ولئه سنكون السلطة لهؤلاء.

צ- طرح مبادر MOOCs في إطار تجريبي؛

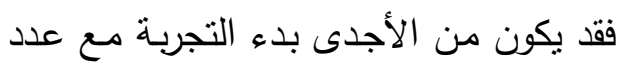
منواضـع من المساقات، فذللك يتيـح منسعًا

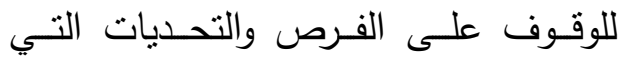
سييرزها اسـتخدام هذا النوع مـن البرامسج

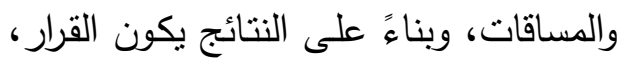

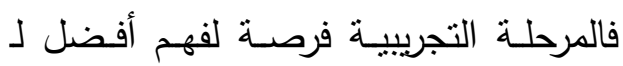
MOOCs. - الاهنمام باتفاقية ترخيص المستخدم النهائي (End-User License Agreement EULA): . ترخيص المستخدم النهائي تهنم بعـلاج

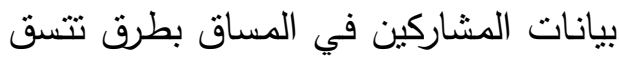

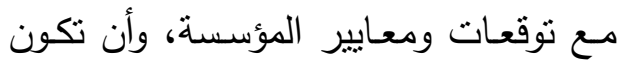
على يقين من أن EULA تتوافق مع قوانين جميع البلدان التي يتم تقديم الدورات فيها.

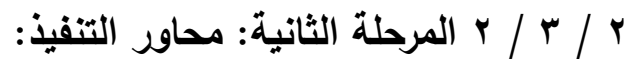
يمكن استثمار ما أسفر عنه البحث في جانبـه التطبيقي مـن قيـاس جهود المنـصات

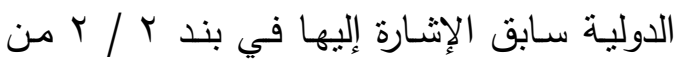

$$
\text { البدء فعليًا في العمل: }
$$

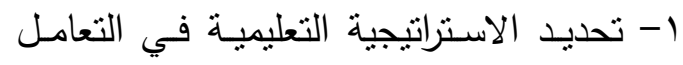
مسع MOOCs : مـن المهم أن تعـرف المؤسسة إذا مـا كانت ستتجه لاستضافة

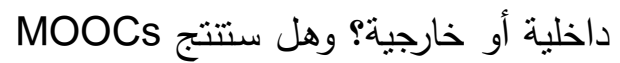

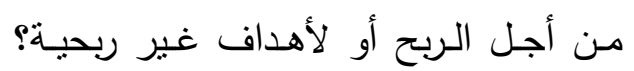
ويلاحـظ وجـود منـصنين مجـانيتين مسن لهن المنصات المبحوثة، وهما إيدكس وكورسبرا، في الوقت الذي تقدم فيه منصة يوداسيتي

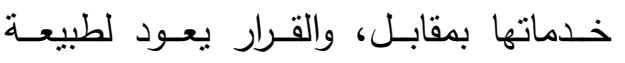
المؤسسة وأهدافها. r- صباغة السياسات المؤسسية لـ MOOCs: على المؤسسة أن لا تفترض أن السياسـات

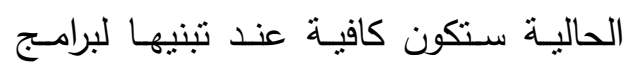
موك، خاصة مع بروز أبعاد لم يعتد عليها

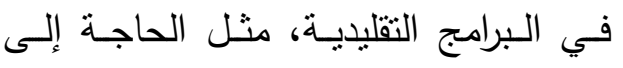
سياسة جديدة لمعالجة حقوق الملكية الفكرية للمسساقات الدراسـية عبر مـوك (كمـشكلة شائكة تبحث عن حل). r- تحديد الأهداف: ينبغسي أن تحدد المؤسسة

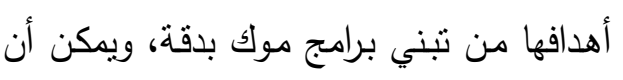

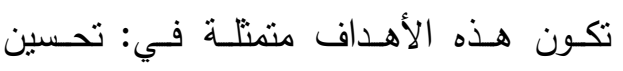
التدريس، وإدرار مصادر جديدة للـدخل، أو هلو تحسين العلامة التجارية. ع- التحقق من التكاليف الفعلية: لابد للمؤسسة

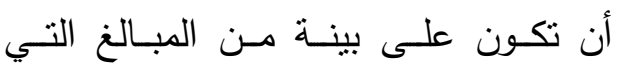

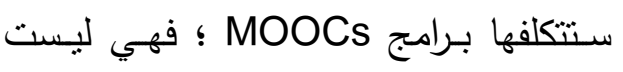
رخيصة، فقد تصل التكاليف المباشرة لإنتاج 
1- امتلاك آليات لتقييم التعليم والتعلم مرتبطة

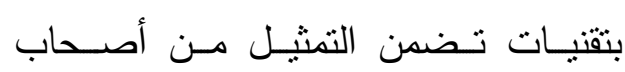
المصلحة الرئيسبين.

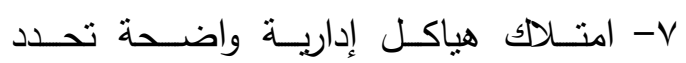
المسئوليات والسلطة.

^- اتخاذ القرارات بشأن اعتماد التقنية الجديدة ضمن أطر السياسة الحالية.

9- تطوير الموظفين الإداريين و أعضاء هيئة التدريس في مختلف المجالات المتصلة بيرامج MOOCs لضمان الجودة أيضًا. المحور الثاني: التطوير المهني لأعضاء هيئة التدريس: توفـر المنـصات عـددًا مـن المعاييـر والآليات المهمة للنطوير المهني لأعضاء هيئة التدريس. تتمنل فيما يلي:

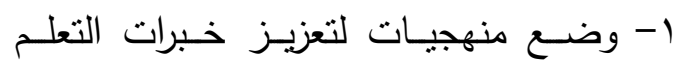
التفاعلية. r- تطوير المواد التعليمية. ץ- معرفة جيدة بالتطورات التكنولوجية الجديدة، فضلاً عن استخدام مزيج من التقنيات. ع- تسويق برامج MOOCs عبر الإنترنت. ه- ضـمان توافـر المساعدة الكافيـة لتسهيل بلريل التعلم. - الت

MOOCS اســتراتيجيات تقييــ بـرامج ومخرجاته.

- معرفة جيدة ببعض العمليات التقنية (مثل

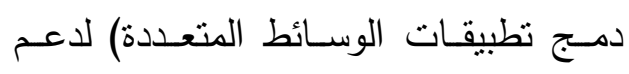
وتوجيه المتعلمين.

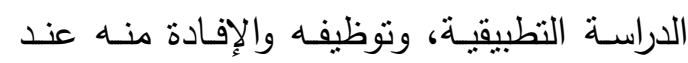
تتفيـذ المنصة العربيـة، خاصسة في الجانبيـن التزبوي والتقني. ويمكن الوقوف على محساور تتفيذ المنصة العربية المستهدفة فيما يلي: المحور الأول : المنظومة الإدارية: أشنار برنامج إطار ضمان الجودة لرابطة

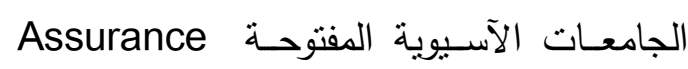
Framework of the Asian Association of Open Universities AAOU مجـالات أساسـية لعمليـة التطويـر الإداري

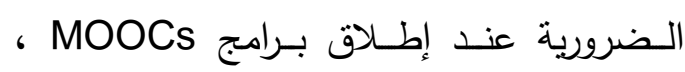
تمنلت في: (Bates, Tony, 2014) 1- التأكد من أن الخطط الاستراتيجية والبرامج التشغيلية للمؤسسة التعليميـة تعزز وتدعم اسـتخدام التقنيـات وتـسهل عمليـة التعليـم لعزئ r- التأكد مـن تماثـى خطط واسـتراتيجيات

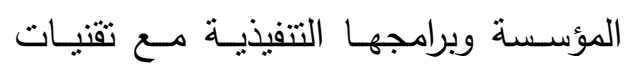
التعليم والتعلم باستخدام برامج MOOCs.

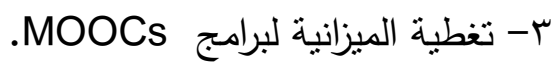

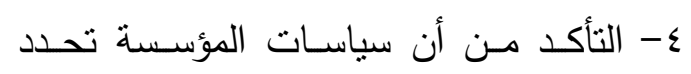

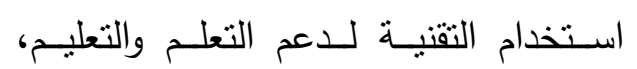
وتضمن تغطية جميع الجوانب والتوافق مع

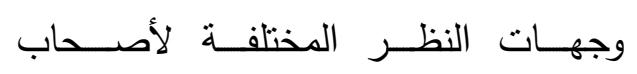
المصلحة. 0- العمل على نشر وتعميم السياسات والتأكد

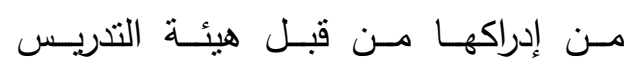
والمتعلمين ومتابعة تطبيقها. 
أساسية، والجهود الحقيقية لتعزيز الجودة. وينبغـي للمؤسـسات الاطــلاع علـى تجــارب المؤسسات الأخرى التي قطعت شوطًا في هذائا المضمار - وذلك لضمان الجودة - والتي في كثير من الأحيان يكون لديها مكتب أو وحدة أو

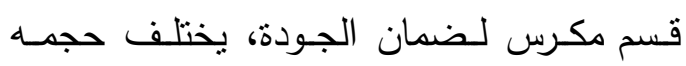
ونطاقه تبعًا لطبيعـة المؤسسة. وعـادة مـا تقوم هذه الأقسام بتتسيق عمليات مراجعـة الجودة

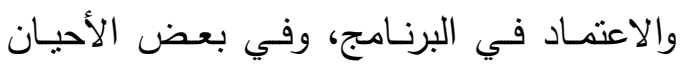

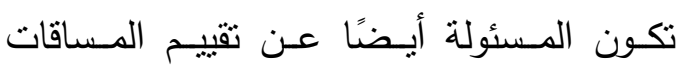
والبحـوث والقيـاس واحتـساب مؤثـرات الأداء الرئيسة (KPI) لإخـراج التقارير حـول جـودة العمل. ولكن في المقابل فإن بعض المؤسسات تضع هذه المهمة ضمن مسئولية أعضاء هيئة التدريس أو القسم. في النهاية، أيًَا كان المسئول عن رصد وتقييم نوعية العمل والجودة التي يتم بها، لابد من توثيتق للعمليات والنتائج وتحديد المسئوليات بوضـوح وامتـلاك سـلطات لاتخـاذ القرار المناسب؛ فبدون صـاحيات صنع القرار ، يمكن أن تصبح مثل هذه العمليات مجرد ثقافة لامتثال.

المحور الرابع: توافر الموارد المالية:

ينبخــي أن تـستتد القــرارات المتعلقـة بتخـصيص المـوارد لتطويـر جـودة برامسـج عOOCS حقيقية للتكلفة.

وترتبط تكلفة مساقات MOOCs بخمسة

مؤثرات، وهي ما يطلق عليها مسببات التكلفة أو
1- القدرة على تقديم الدعم الفني، وخاصـة فيما يتصل بتصميم المساقات. 9- التأكد من أن أعضاء هيئة التدريس لايهم شبكة معرفية تسنطيع تقديم خدمات الدعم الطلابية. • 1- التأكد مـن أن المؤسسـة التعليميـة على

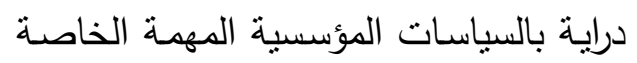

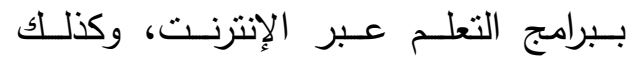
الإجراءات الإدارية ذات العلاقة.

تجدر الإشارة إلى توافر العمليات السابقة

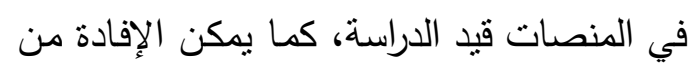

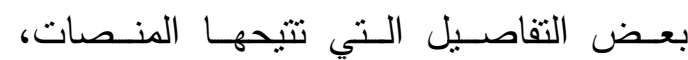
والمتمتلة فيما يلي: 1- إتاحـة برامج تدريب يتم منحها للأعضاء والمدربين. r-إمداد هيئة التدريس ببعض المواد التعليميـة

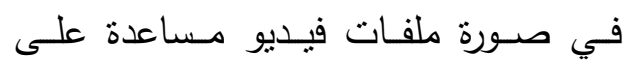
الإعداد الجيد للمساقات.

r- توفير المنصات لمجموعات الدعم المساعدة في الإنجاز • المحسور الثالـث: جـودة الهياكـل المؤسـسية والموارد البشرية: يتطلـب ضــمان جـودة التعليـم عبـر الإنترنت هياكل مؤسسية فعالة وعلى قدر عالٍ

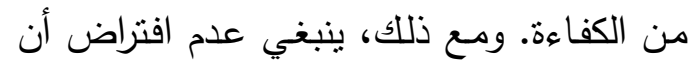
إنشاء هياكل مؤسـسية سيحسن مـن الجـودة تلقائيًا؛ حيث ينبغي التمييز بين إجراءات ضماء ضئهن الجودة، والتي يمكن أن تصبح بسهولة ركيزة 
1- عدد الساعات المطلوبـة لإعداد المساق

$$
\text { وتطوبره. }
$$

ץ- عدد الساعات المطلوبة لتدريس المساق.

$$
\begin{aligned}
& \text { ץ- عدد الملتحقين بالمساق. } \\
& \text { ه- جدول أجور المدربين . }
\end{aligned}
$$

؟- طريقة تصميم المـادة التدربييـة وإعدادهـا

$$
\text { وطرق تقديمها. }
$$

V- طرق التدريس الـستخدمة، مـن حيث

المنهجية البنائية والموضوعية.

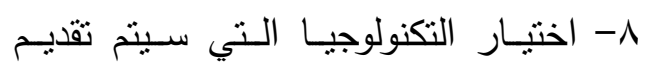

المسساق مسن خلالهـا مثـل: تسجيل

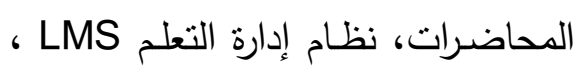

$$
\text { تقييم المساق ونتائجه. }
$$

9- عملية تقييم المساق ومخرجاته.

• 1- التكاليف العامة مثل التكاليف الإدارية،

$$
\text { وتكاليف الثبكة... الخ. }
$$

تجدر الإثارة إلى حصول المنصات، قيد

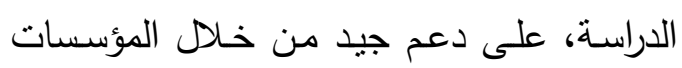

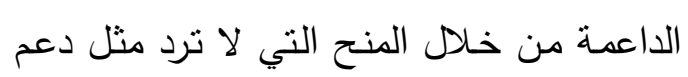
مؤسسات وادي السليكون لكورسيرا، أو الدعم

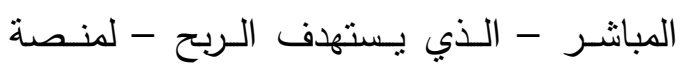
يوداسيتي من قبل مؤسسيها، وقد أشـار الباحث

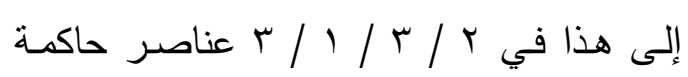

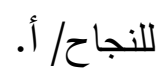

المحور الخامس: كفاءة البيئة الافتراضية: تتكون بيئات التعلم الافتراضية لبرامج

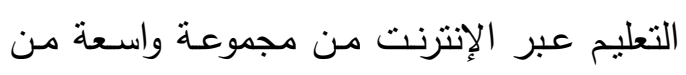
الأدوات، التي ينبغـي أن تتسم بالكفـاءة والدقـة
محركات التكلفة Cost Drivers وتؤثر هذه العوامل في التكلفة، بمعنى أن التغير في محرك التكلفة بسبب التغير في إجمالي التكلفة المرتبطة والمتعلقة بغرض التكلفة. وتتمثل هذه المحركات

- التخطيط لتطبيق البرامج.

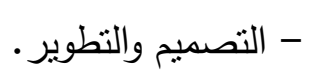

- التسليم (وتشمل السياسـات والإجـراءات

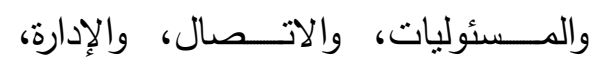

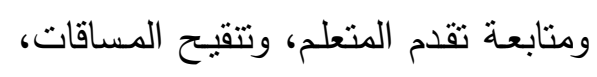
والمنطلبات التقنية، وغيرها).

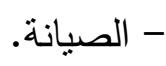
- النفقات غير المباشرة، وتتمثل فيما يلي: - البنية التحتية للتكنولوجيا المستخدمة، مثل الأنظمـة الـصوتية وتخـزين المعلومـات

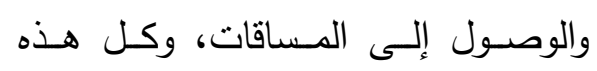
عناصر حاسمة في الجودة .

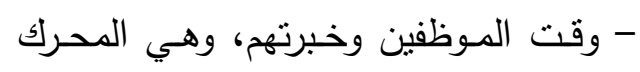

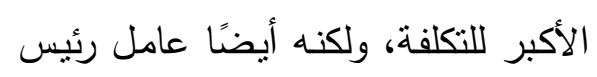
لجودة برامج MOOCs. وتوفـر بوابـة التعلـم الإلكترونـي فـي بردي أونتـاريو للكـادر الأكاديمي والمدرسـين Ontario Online Learning Portal for Faculty and Instructors • 1 عوامل مؤثرة في تكاليف التعلم عبر موك

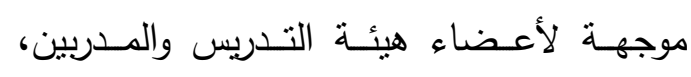
وتمثلت في العناصر التالية: (Bates, Tony) 2014) 
العدد الرابع والخمسـون - 7 •

تكـشف عمليــات انتحـــال الشخــصية Plagiarism كما بمكن تصميم عملية التقييم الإككترونيـة بطريقـة تسـاعد في تقليـل عمليـة الاحتيـال عبر تغيبر طبيعـة وتكرار الواجبـات وتقسيم المهام إلى أجزاء؛ مما يتطلب تقديم أكثر من حل. وجميع ما سبق يوظف فعليًا من خلد اهل

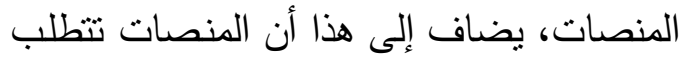
وسبلة سـهلة للتحقق من هويـة المستقبد أثتاء التقويم، وهي كاميرا الويب المدمجة، وفي حال عدم توافرها بمكن استخدام كاميرا ويب خارجية بسيطة منصلة من خلال منفذ USB، كما بمكن لون

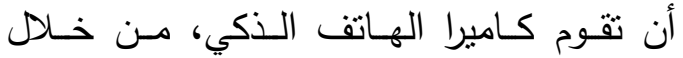
توصيلها بجهاز الكمبيوتز بالمهمة ذاتها. المحور السابع : تحقيق رضا العملاء: تمثل وجهة نظر المتعلم جانبًا مهمًا من جوانب ضمان الجودة لبرامج MOOCs؛ فجودة التعليم عبر الإنترنت تتم مـن خـله عمليـة الإنتاج المشترك بين المتعلم والبيئة التعليميـة. ويصبح الحصول على رضـا المتعلمين هدفًا محوريًا يجب أن تصل إليه المؤسسة التعليمية حتى يكتب لها النجاح والاستمرارية.

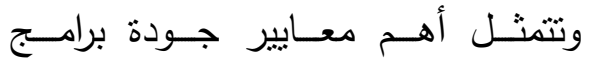
مس وجهـة نظر المتعلميـن فيما يلي: (Bates, Tony, 2014) ا- توفير الدعم التعليمي باستخدام مجموعـة

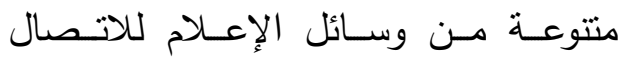
والتواصل.

r- الطريقـة والـسياق الـذي تتـم فيـه عمليـة
والمرونـة العاليـة ، وتثمثل هـذه البيئة في : محركات البحث، والاتصالات الصوتية عبر الإنترنت، والرسائل الفورية، والدردشـة ، ورسائل

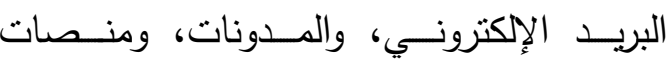

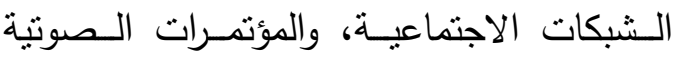
Audio Conferences Video Conferences MOOCs العملية التعليمية؛ والتي تزود الكادر التعليمي لهي لهيه بأحسدث الحسـول المـصممة خصيـصاً لتلائم أساليب التدريس والتدريب الحديثة. ونتعلق كفاءة البيئة الافتراضية بمكونات النظام بصفة عامة، مع التأكيد على التقنيات التقاعلية. وتمثل البيئة الافتراضية أحد المعايير الحاكمة التي لا يمكن للمنصة النجاح بدونها، ومن خلال الوقوف على واقع المنصات المبحوثة ثبت للباحث تفوقها في هذا الجانب، على كافـة الأصسعدة من حيث: التجهـيزات الأساســية، والمكونــات، والبيئــة التعليمية من حيث المحتوى التعليمي التفاعلي، والتكنولوجيـات المستخدمة، والـدعم، وإمكانيـات الوصـول، والـتي يمكن الأخذ بهـا وتوظيفها للإفادة منها في تطوير المنصة المستهدفة. المحور السادس: تحقيق أمن الاختبارات: لـضمان جـودة بـرامج مـوك فلابـد مـن

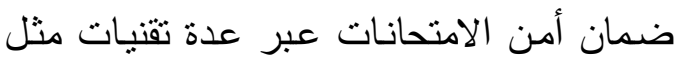
تحديد الهويبة إلكترونياً، وقارئ البصمة لتحديد

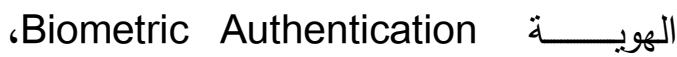
واستخدام البرامج الحديثة لأمن الامتحانات، التي 
0- التواصل مـع خبراء الصناعة للتعرف على التى

احتياجات سوق العمل، والفرص المتاحة.

ج- الاتصال بالدعم الفني للمساعدة على مدار استخدام المساقات.

\section{المحسور الثـامن: تحقيـق المنظومـة المتكاملـة} للإودة :

أدى النمو المطرد للتعليم عبر الإنترنت في : دول مختلفة في العالم، والانتشار السريع للمساقات

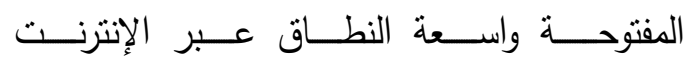

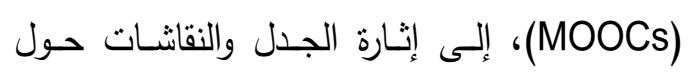

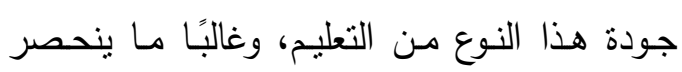
التوتر بين دورين لضمان الجودة: كونها وسيلة هدان

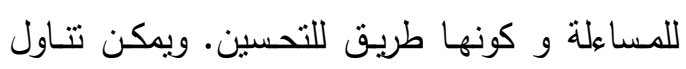
أهم عناصر الجودة في برامج MOOCs المتاحة

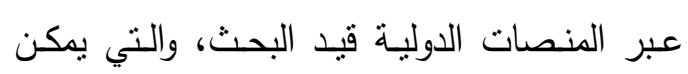
توظبفها في المنصة المستهدفة فيما يلي: ا- الدعم والالتزام المؤسسي: ويشمل الالتزام

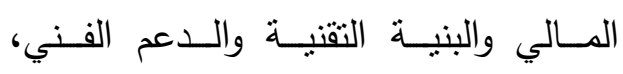
والسياسات.

r- خدمات المتعلم: وتشمل الخدمات التي تتم قبل الدخول إلى البرنامج، وأثناء التعلم، وبعد الاتتهاء

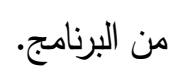

r- التصميم التعليمي وتطوير المساق: وتعنى لئى

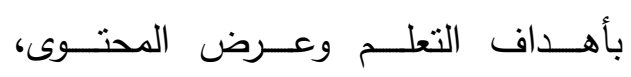

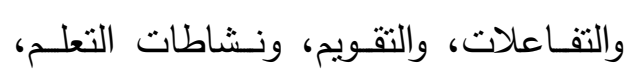

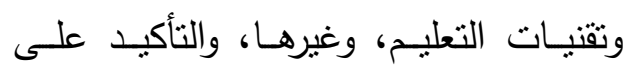

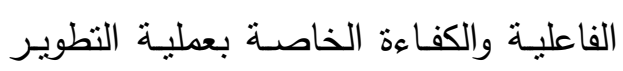

"الإنتاج" ذاتها.
المشاركة والاتصال.

r- المعايير التقنية، وهي عامل مهم بالنسبة

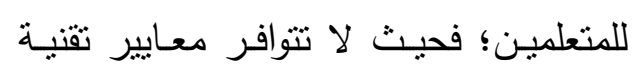
تقابل احتياجاتهم تتولد لديهم تجربـة سلبية للغاية نحو المساق.

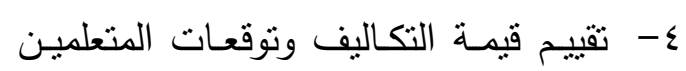
للقيمة التي سيضيفها المساق؛ فالمتعلمون يقارنون التكلفة بالعائد عند الحكم على جودة برامج MOOCs. ه- الشفافية وتوافر المعلومـات عن المساق ئراق والمؤسسة التي تقدم المادة التعليمية.

$$
\text { 7- بناء المادة ومرونتها. }
$$

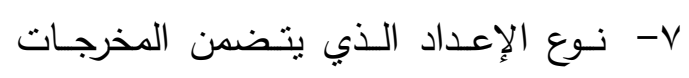

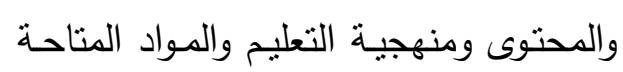

$$
\text { عبر الإنترنت. }
$$

ويمكن الإفـادة مـن المنـصات بـشكل

مباشر - إضـافة لما سبق - من خلال توفيرها لما يلي، بهدف الوصول لرضا المتعلمين: 1- استبيانات، تستهدف قياس رضا المتعلمين. r- التفاعل المباشر من خلال هيئة التدريس. r- توفير تعليمات مفصلة حول كل المفاهيم

$$
\text { والعمليات بشكل آني. }
$$

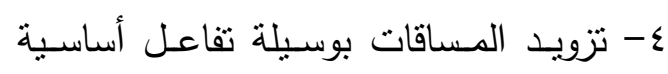

لتلقـي استفـسارات المتعلميـن، وإمكانيــة

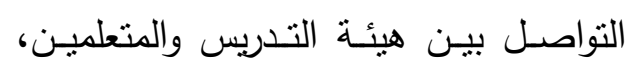

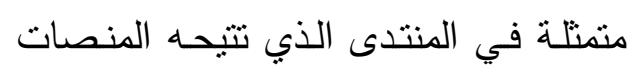

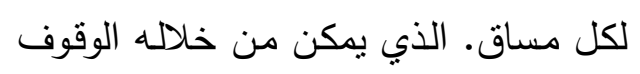

$$
\text { على درجة رضا المتعلمين. }
$$


تقديمه • ـأسابيع، ودرسه البروفيسور حسام

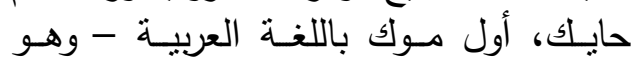

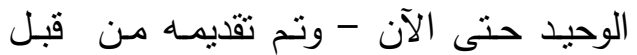
جامعـة تيخيون الإنسرائيلية - Technion Israel Institute of Technology r. وجـود تجـارب جيدة مـن قبـل المؤسسات

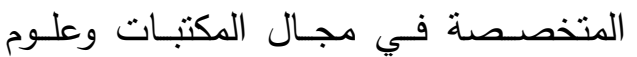

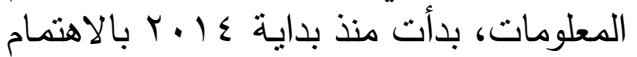

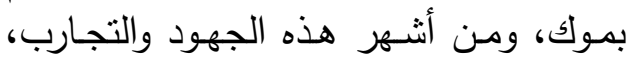

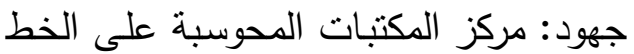
المباشر OCLC، والاتحاد الدولي لمؤسسات المبات المبات

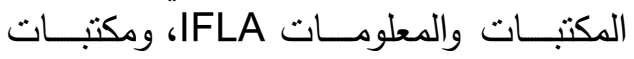
جامعة بنسلفانيا الجامعيـة، ومكتبـة نيويورك

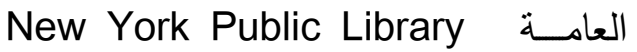
NYPL ومشروع إيركس للمكتبات الكونية

IREX's Global Libraries project

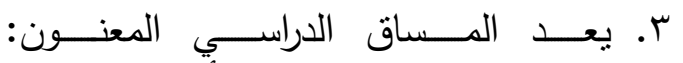
"Hyperlinked Library" دراسي قدم في مجال المكتبات والمعلومات، أرل وهو المساق الوحيد المتخصص في في المجال حتى الآن. ثانيًا على المستوى التطبيقي:

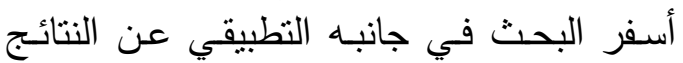
التالية:

ا ـ من خلال تطبيق معايير موك التي وضعتها

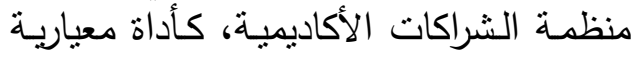

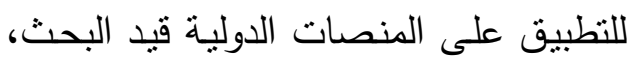

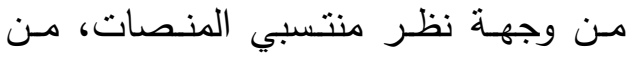

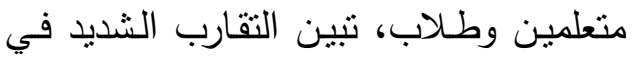

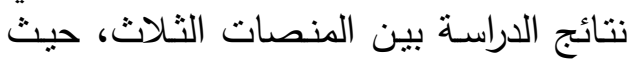

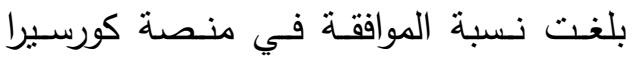

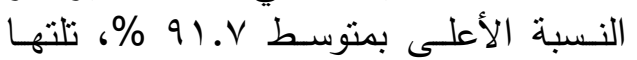

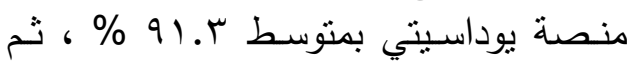

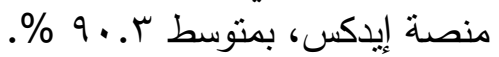

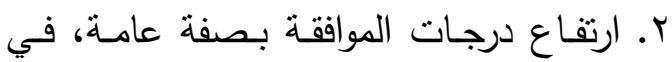
المنصات الثلاث. r. التوافق بين النتائج وواقع المنصات.
ع- التدريس وهيئة التدريس: وتشمل تشجيع الاتصال الفعال بين عضو هيئة التدريس ونئس

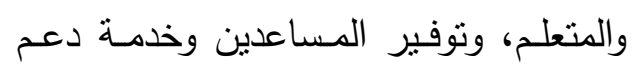

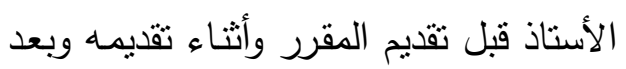
الانتهاء منه.

ه- نظــام التوصــيل: وتــشمل السياســات التهاء

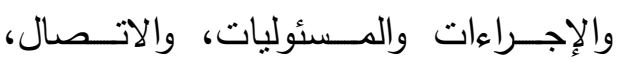
والإدارة، ومتابعـة تقـدم المتعلـم، وتتقبـح المساقات، والمتطلبات التقنية، وغيرها.

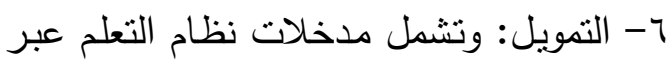
موك وإدارة عملياته. -V والقوانين المعدول بها في منظومـة مـوك (وهي ما تزال مشكلة شائكة حتى الآن). 1- التقنية: وتتعلق بمكونات النظام مع التأكيد على النقنيات التفاعلية. 9- التقويم: وهي خاصـة بجميع جوانب برنامج

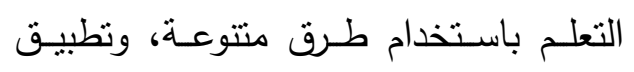

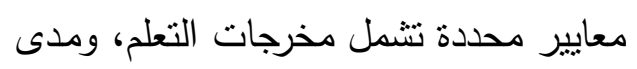

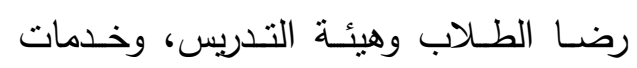
مصادر التعلم، والإتاحة، وتقدير الفاعلية، وهلئ والتكلفة وغيرها. r. النتائج والتوصيات: ب / / النتائج: أولاً على المستوى النظري: ا ـ يعد المساق المعنون "التقانة والمستشعرات المعين

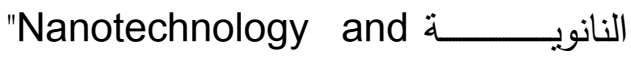
Nanosensors

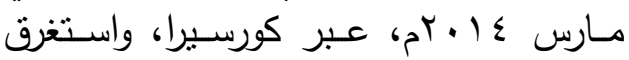


who-we-are/about-academy?

$\mathrm{t} \mathrm{m} \mathrm{p} \mathrm{l}=\mathrm{c}$ o $\mathrm{m} \mathrm{p}$ o $\mathrm{n}$ ent\#ixzz3JxnJRuno)

- الوسائل المتاحة.

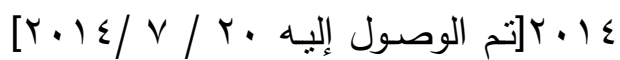

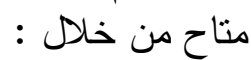

http://aldarayn.com/index.php/ w h o - w e -a r e / m e a n s .available\#ixzz3JxnB8orw))

(ع) بدر بن عبداله الصالح. التصميم التعليمي

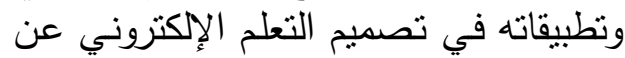

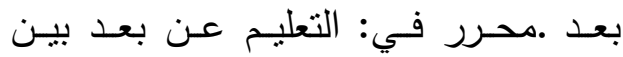

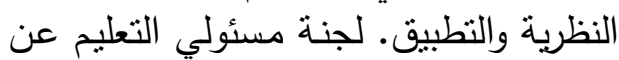

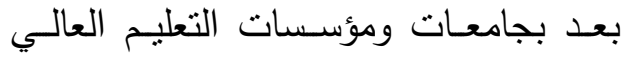

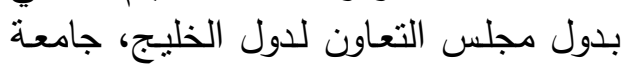

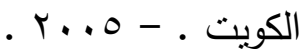

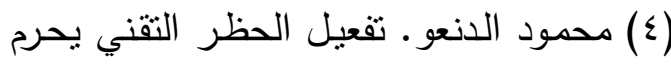

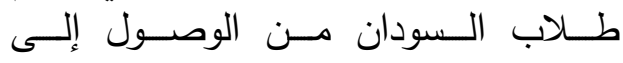

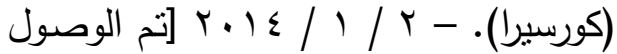

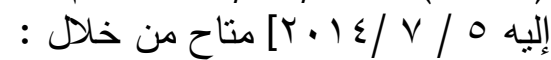
http://www.alnilin.com/news-

.(action-show-id-83899.htm)

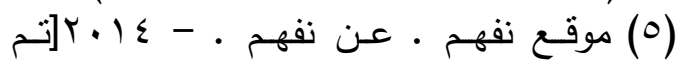

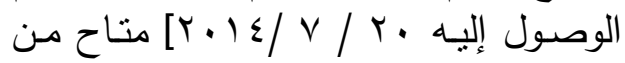
http://www.nafham.com/: خـلاحل (about)

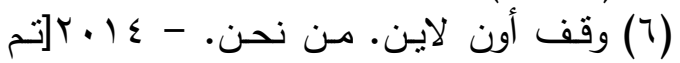

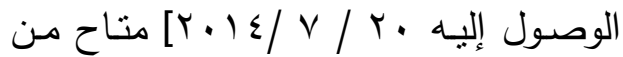
خله :

http://www.waqfonline.com/ .(aboutus)

(7) Academic Partnerships. Standards. - 2013[Cited 2 7 /2014]. -Available at:(http:// www.academicpartnerships.co $\mathrm{m})$.

(8)

Creating

virtual campuses within great

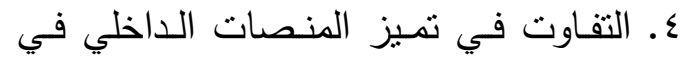

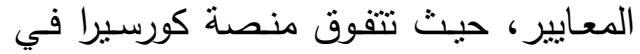

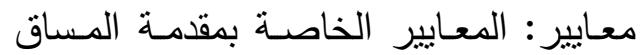

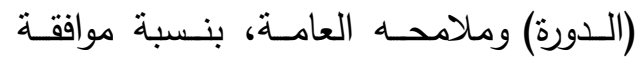

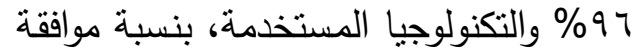

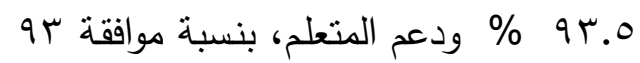

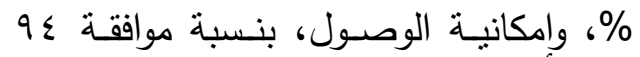

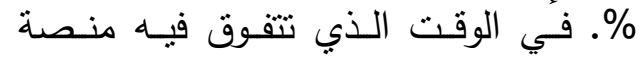

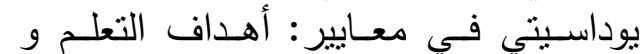

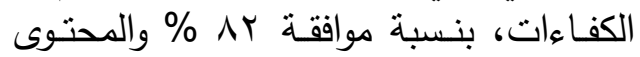

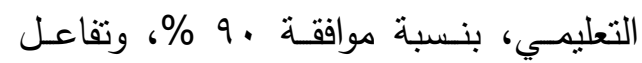

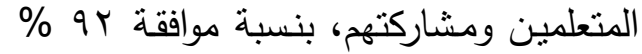
كما تتفوق منصة إيدكس في التقييم والقياس،

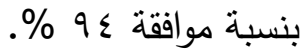

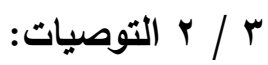

ا ـ من خلال قراءة النتائج السابقة، التي أكدت

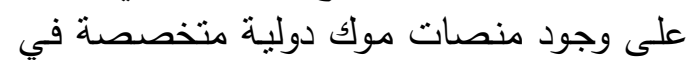

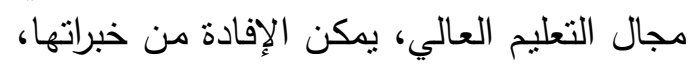
يوصي الباحث بأهمية إنشاء منصة موك العيم عربية

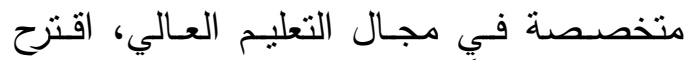

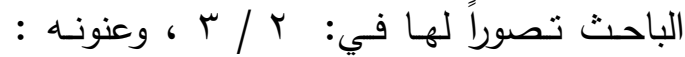
"التصور المقترح لمنصة موك عربية متخصصة في مجال التعليم العالي". Y. الاهتمام بإنتاج مزيد من موك متخصص العص في مجال المكتبات وعلوم المعلومات.

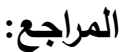

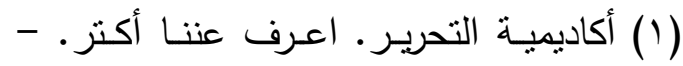

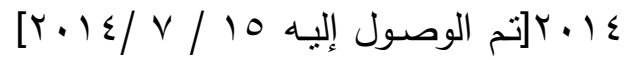
مناح من خلال : من الوصول http://www.tahriracademy.org/ .about/))

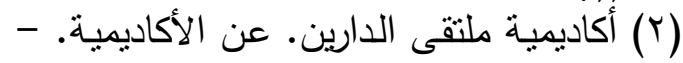

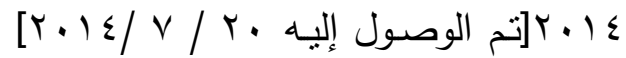
مناح من خلال : (http://aldarayn.com/index.php/ 
العدد الرابع والخمسـون - 17 •

http://www.babson.edu/aboutbabson/at-a-glance/Pages/ default.aspx.(?

(14) Bates, Tony. E-learning quality assurance standards organizations and research.2014 [Cited 15 / 8 /2014]. Available at:(Tonybates.ca/elearning-quality-assurancestandards-organizations-andresearch).

(15) Balch,Tucker , 2014. - 2014. - [Cited 20/ 11/ 2014]. Available at:

http://

augmentedtrader.com/2013/01/27/ mooc-student-demographics/

(16) Bombardieri, Marcella . Can you MOOC your way through college in one year? . - 14 April 2013[Cited 30 / 7 /2014]. - Available at :http://www.bostonglobe.com/ ideas/2013/04/13/can-youmooc-your-way-throughcollege-one-year-can-youmooc-your-way-throughc o I l e g e -o n e -y e a r / IAPwwe 2OYNLbP9EHitgc3L/ story.html(

(17) Booker, Ellis .Early MOOC Takes A Different Path.30 / 1 / 2013[Cited $30 / 7$ /2014]. Available at:

$\left(\begin{array}{lllllll}\mathrm{h} & \mathrm{t} & \mathrm{t} & \mathrm{p} & : & /\end{array}\right.$ www.informationweek.com/ software/early-mooc-takes-adifferent-path/d/d-id/1108432)

(18) Burlingame, Russ. Teaching Gender Through Comics With universities. -2014[Cited 2 / 7 /2014]. -Available at: (http:// www.academicpartnerships.co $\mathrm{m} /$ about).

Coursera., community. - 2014. - [Cited 20/ 7/ 2014]. - Available at:

(https://www.coursera.org/ about/community)

(9) ALA..Presidential Committee on Information Literacy: Final $\mathrm{Re}-$ port. 10 / 1 / 1989 [Cited $10 /$ 7 /2014]. -Available at:

http: //www.ala.org/acrl/ publications/whitepapers/ presiden

(10)_-Summit on the Future of Libraries. - 3 / 5 / 2014[Cited 15 / 8 /2014]. -Available at: (ht tp: //connect.ala.org/ node/219621)

(11)Almeida,Nora.A New Polemic: Libraries, MOOCs, and the Pedagogical Landscape. - $21 /$ 8 /2013[Cited 15 / 8 /2014]. Available at:

$\mathrm{h} \quad \mathrm{t} \quad \mathrm{t} \quad \mathrm{p}: \mathrm{l} /$ www.inthelibrarywiththeleadpipe .org/2013/a-new-polemiclibraries-moocs-and-thepedagogical-landscape/.(

(12) Auer,Sören . First Public Beta of SlideWiki.org. 7 / 2 / 2013 [Cited 15 / 8 /2014]. Available at:(http:// blog.aksw.org/2013/firstpublic-beta-of-slidewiki-org/).

(13) BABSON College. at a glance. - 2014[Cited 15 / 8 /2014]. Available at: 
http://www.educause.edu/ blogs/accidentalcio/why-moocs -are-farmville.(

(23) Colman, Dan . MOOC Interrupted: Top 10 Reasons Our Readers Didn't Finish a Massive Open Online Course. Retrieved 5 Sep.,2014. Available at:

(10_reasons_you_didnt_compl ete_a_mooc).

(24) Coursera., About. - 2014. [Cited 20/7/ 2014]. - Available at: https://ww.coursera.org/ about.(

(25) Services. 2014. - [Cited 20/ 7/ 2014]. Available at: https:// www.coursera.org/Services.(

(26)- community. - 2014. [Cited 20/7/ 2014]. - Available at:https://www.coursera.org/ about/community) 2014. - [Cited 20/ 7/ 2014]. Available at: https:// www.coursera.org/about/ partners.(

(28) Duke University .Duke University Report. Student Persistence in Bioelectricity(Duke University MOOC). $20 / 2 /$ 2013. - [Cited 20/7/2014]. Available at: http://alternative $-$ educate.blogspot.com/2013/02/ duke-universitys-first-moocreport.html)

(29) EDX. About.22 / 10 / 2014 .
Christina Blanch, Part 1. Comic Book. - 23 / 3 /2013[Cited 25 / 7 /2014]. -Available at: ht tp: //comicbook.com/ blog/2013/03/23/teachinggender-through-comics-withchristina-blanch/.(

(19) Canvas Network. Course evaluation: Taking the measure of MOOCs, 2013[Cited 25/ 2/205]. -Available at: https://s3.amazonaws.com/ omekanet/9352/archive/files/ d $533 \mathrm{c} 3$ ad 7 c 772 c 25 a 73 8207 b 450 e ad 22 .jpg? $A W S$ A c c e $S$ S Keyld=AKIAI3ATG3OSQLO5H GKA\&Expires $=1428568536$ \&Signature=PildYkthU9zapy\% 2BdkeCjbEzEFbc\%3D).

(20) Carr, David F . "Udacity hedges on open licensing for MOOCs". Information Week. 20 / 8 / 2013. - [Cited 21/ 7/ 2014]. - Available at :

$\begin{array}{llllll}\mathrm{h} & \mathrm{t} & \mathrm{t} & \mathrm{p} & \mathrm{:} & \text { / / }\end{array}$ www.informationweek.com/ software/udacity-hedges-onopen-licensing-for-moocs/d/did/1111226?

(21)Catropa, Dayna .Big (MOOC) Data. Inside Higher Ed.- 24 February 2013 [Cited $30 /$ 7 /2014]. -Available at:(http:// www.insidehighered.com/blogs/ stratedgy/big-mooc-data)

(22) Chester, Timothy M. .Why MOOCs are like Farmville. 2013[Cited 15 / 8 /2014]. Available at: 


\section{( https://www.coursera.org/ course/nanosensors).}

(35) IFLA. About IFLA $14 / 5 /$ 2014[Cited 30/7/2014]. Available at:

(http://www.ifla.org/about)

(36) . Report Trend 5/11/ 2014[Cited $30 / 7$ / 2014]. Available at:

(http://trends.ifla.org(/

(37) IREX .About IREX. - 2014 [Cited 15 / 8 / 2014]. - Available at:

(http://irexgl.wordpress.com/ about-2/)

(38) Jordan, Katy. MOOC Completion Rates: The Data.- 24 February 2013 [Cited 30 / 7 / 2014]. - Available at:

(http://www.katyjordan.com/ MOOCproject.html)

(39) Kazakoff, Carmen. Keeping Up With... MOOCs . - 2014[Cited $\overline{15 / 8 / 2014]}$. - Available at: $(\mathrm{h} t \mathrm{t} \quad \mathrm{p}: \mathrm{l} /$ moocstarter.digischool.com/? gclid=Clag4d6kkclCFcrLtAodOjc AoQ)

http://www.technologyreview.com/ new s/512256/in-thedeveloping-world-moocs-startto-get-real/).

(40) Kellogg, Sarah .How to make a MOOC - - Nature. - 499, (2013). - pp. 369-371[Cited 2 / 7 / 2014]. - Available at: (http://www.nature.com/ $\mathrm{n}$ a t u rejobs / s c i ence / articles/10.1038/nj7458-369a)

(41) Kolowich, Steve .Coursera takes a nuanced view of $\mathrm{MOOC}$ dropout rates. The Chronicle of 8 April 2013[Cited 30/7/
- [Cited 20/ 11/ 2014]. -

Available at:(https:// www.edx.org/about-us).

(30) Freedom,Degreeof. XMOOC vs. cMOOC . - 29 / 4 / 2013 [Cited 15 / 8 /2014]. Available at:(http:// degreeoffreedom.org/xmoocvs-cmooc/)

- $[r \cdot \mid \leq / \wedge / 10$ Available at: (http://www.nypl.org/help/ about-nypl)

(31) Gashurov, Irene, Curtis Kendrick.Can Libraries Save the MOOC?

[11/6/2014-Cited $2 /$ 9 /2014]. -Available at: http:// campustechnology.com/ articles/2014/11/06/canl i braries -s a v e -t h emooc.aspx3.

(32) Germain,Elizabeth St. . Five Common Pitfalls of Online Course Design. - $6 / 11 /$ 2011[Cited $15 / 7 / 2014]$. Available at: (http:// www.facultyfocus.com/articles/ online-education/five-common -pitfalls-of-online-coursedesign.(/

(33) Honeyman, M; Miller, G. Agriculture distance education: A valid alternative for higher education?. Proceedings of the 20th Annual National Agricultural Education Research Meeting. - December 1993. pp 67-73

(34) H o s a m H a i c k. Nanotechnology and Nanosensors. - 2013[Cited 2 / 9 /2014]. -Available at: 
ing in a MOOC. - Proceedings of the 7th International Conference on Networked Learning 2010[Cited 25 / 7 / 2014]. Available at:

(http://www.lancs.ac.uk/fss/ organisations/netlc/past/ nlc 2010 /abstracts/PDFs/ Mackness.pdf).

(47) McConnell, Kathryn. Online University Courses Revolutionize Learning By Staff Writer . 18 / 12 / 2012[Cited 25/7/ 2014]. - Available at:(http:// iipdigital.usembassy.gov/st/ \begin{tabular}{llllllll}
\hline $\mathrm{e}$ & $\mathrm{n}$ & $\mathrm{g}$ & $\mathrm{l}$ & $\mathrm{i}$ & $\mathrm{s}$ & $\mathrm{h}$ & \\
\hline $\mathrm{a}$ & & $\mathrm{r}$ & $\mathrm{t}$ & & $\mathrm{i}$ & &
\end{tabular} cle/2012/12/20121218140095. html\#axzz3JplxIrih).

(48) New York Public Library .About The New York Public Library. 2014. - 2014[Cited 22 / 11 /2014]. - Available at: (http://nypl.about.org).

(49) Nurhayat, Wiji (2013-08-25). "Mau Belajar Jadi Pengusaha Secara Gratis? Ini Caranya". detik.com. . - 25/8/2013 [Cited $30 / 7$ / 2014]. - Availa ble a t : ( h t t p : / fin a n c e.detik.com read/2013/08/25/103637/233 9721/4/mau-belajar-jadipengusaha-secara-gratis-inicaranya).

(50) NPR. Stanford Takes Online Schooling To The Next Academic Level. All Things Considered, National Public Radio. 23 January 2012. [Cited 22 / 7 / 2014]. - Available at: (http://www.npr.org/blogs/
2014]. - Available at:

(http://chronicle.com/blogs/ wiredcampus/coursera-takes-a -nuanced-view-of-moocdropout-rates/43341).

(42) Kolowich, Steven. "The Professors Who Make the MOOCs". Chronicle of Higher Education. 2013. - 22/

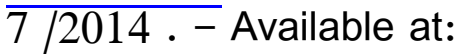

(http://chronicle.com/article/TheProfessors-Behind-theMOOC/137905/\#id=overview)

(43) Leber, Jessica . In the Developing World, MOOCs start to get real. - 15 / 3 / 2013[Cited 30 / 10 / 2014]. - Available at: ??

(44) Lewin, Tamar . "Universities Abroad Join Partnerships on the Web". New York Times. $\overline{20 / 2 / 2013 . ~-~ R e t r i e v e d ~} 6$ March 2013. - Available at:

( $\frac{\mathrm{h} \text { t } \mathrm{t} \quad \mathrm{p}: \text { : / / }}{\text { wwwtimes.com/2013/02/21/ }}$ education/universities-abroadjo i n -mooc- course projects.html).

(45) MacKay, R.F. (11 April 2013). "Learning analytics at Stanford takes huge leap forward with MOOCs". Stanford Report. Stanford University. Retrieved 22 April 201-. Retrieved 13 Sep.,2014. - Available at:

(http://news.stanford.edu/ news/2013/april/onlinelearning-analytics041113.html).

(46) Mackness, Jenny, Mak, Sui Fai John, and Williams, Roy .The Ideals and Reality of Participat- 
العدد الرابع والخمسـون - 7 •

flexible delivery: Creating a conceptual framework and model. The Journal of Academic Librarianship, v.26, n.6, 2001 . ¿ Tr - sov. -

(58) Pappano, Laura. "The Year of the MOOC". The New York Times. - 4 /11/ 2012. -[Cited 21/ 7/ 2014]. - Available at: (http:// www.nytimes.com/2012/11/04/ education/edlife/massive-openonline-courses-are-multiplying -at-a-rapid-pace.html? pagewanted=all\&_r $=1$ (\&

(59) Penn Libraries. Services. 2014[Cited 15 / 8 / 2014]. Available at:

$\begin{array}{ccccc}\mathrm{h} & \mathrm{t} & \mathrm{t} & \mathrm{p} & :\end{array} / /$

(60) Perez-Pena, Richard. Harvard asks graduates to donate time to free online humanities class . - The New York Times . -25/ 3 / 2013[Cited 25 / 7 / 2014]. Available at:

( $\mathrm{h} \quad \mathrm{t} \quad \mathrm{t} \quad \mathrm{p}:$ : / / education/harvard-asks-alumni -to-donate-time-to-free-online -course.html)

(61)

universities test the online $\overline{\mathrm{ap}-}$ peal of free.- The New York Times.- 17 July 2012 [Cited July 2012]0 - Available at :

( $\mathrm{h}$ t $\mathrm{t}$ p : / / / education/top-universities-testthe-online-appeal-offree.html).

$\frac{\text { a I t e c h c o n - }}{\text { sidered/2012/01/23/14564547 }}$
$\frac{\text { 2/stanford-takes-online- }}{\text { schooling-to-the-next - }}$
academic-level

(51) OCLC. Libraries, MOOCs and online learning. - 2014. - 2014 [Cited 15 / 8 / 2014]. - Available at: (http://www.oclc.org/en -A U / e v e n t s / 2014 / ANZMOOCS.html)

(52) __ Education, Learning and Libraries at a Tipping Point 25 / 6 / 2014[Cited $30 / 9$ / 2014]. - Available at:

r h t p://oclc.org/news/ leases/2014/201422dublin.en.h tml)

(53)

About. 2014[Cited

$\overline{30 / 7}$ / 2014]. - Available at:

( h t t p : //w w w . oclc.org/ about.en.html).

(54) O'Donnell ,James J. Teaching on the Infobahn . - Religious Studies News. - v. 9,n..3 (1994). - P. 4.

(55) Onink, Troy. Georgia Tech, Udacity Shock Higher Ed With \$7,000 Degree. - 18/4/2012 [Cited $22 / 7 / 2014]$. - Available at

:(http://www.forbes.com/fdc/ welcome_mjx.shtml).

(56) Openuped. MOOCs. -2013 [Cited 25 / 7 / 204]. - Available at:

(http://www.openuped.eu(/

(57) Orr, D., Appleton, M., \& Wallin, M.. Information literacy and 
tium. MOOCs Principles. -2014 [Cited 25 / 7 / 2014]. - Available at: ( http:// www.oeconsortium.org/ members/all/ ).

(68) Udacity. About us. -2014 [Cited 25/7/204]. - Availa b le at : (ht t p s : / www.udacity.com/us)

(69) University of Pennsylvania. MOOCs on the Move: How Coursera Is Disrupting the Traditional Classroom(text and video). -7 / 11/ 2012. [Cited 30 / 7 / 2014]. - Available at: $(\mathrm{h}$ t $\mathrm{t} \quad \mathrm{p}: 1 /$ knowledge.wharton.upenn.edu/ article.cfm?articleid=3109)

(70) Waldrop, M. Mitchell; Nature magazine (13 March 2013). Massive Open Online Courses, aka MOOCs, Transform Higher Education and Science. Scientific American. - 13/3 / 2013 [Cited 30 / 7 / 2014]. - Available at:

( 1 hww.scientificamerican.com/ article/massive-open-onlinecourses-transform-highereducation-and-science/)

(71) Wessel, Madelyn. Long Arm of the Law MOOCs and Not MOOCs. - 9 / 11 / 2013 [Cited 2 / 9 / 2014]. - Available at: (http://www.slideshare.net/ CharlestonConference $/ \mathrm{mw}-$ moocs).

(72) Wiley, David. The MOOC Misnomer . , $7 / \overline{2012 \text {. [Cited }}$
(62) Shapiro, Jeremy J. and Shelley K. Hughes, .Information Literacy as a Liberal Art. Educom Review, 31:2 (Mar/Apr 1996). [Cited 15 / 8 / 2014]. - Available at:

(http://net.educause.edu/apps/ \begin{tabular}{lllllllll} 
e & $r$ & $r$ & e & $v$ & i & e & $w$ \\
\hline
\end{tabular} reviewArticles/31231.html)

(63) Schwartz, Meredith. Massive open opportunity: Supporting MOOCs in public and academic libraries. - 10 / 5/2013 .Retrieved 15 Sep.,2014. Available at:

(http://lj.libraryjournal.com/2013/05/ library-services/massive-openopportunity-supportingmoocs/).

(64) Sherry, L. Issues in distance learning . - International Journal of Educational Telecommunications. - 1(4) (2009). pp337-365.

(65) Smith, Lindsey .5 education providers offering MOOCs now or in the future.- $31 / 7 / 2012$. - [Cited 21/ 7/ 2014]. - Available at : ( ht p:// www.educationdive.com/ \begin{tabular}{lllllllllll}
\hline $\mathrm{n}$ & $\mathrm{e}$ & $\mathrm{w}$ & $\mathrm{s}$ & $\mathrm{C}$ & 5 & $-\mathrm{m}$ & $\mathrm{O}$ & $\mathrm{o}$ & $\mathrm{c}$ & - \\
\hline
\end{tabular} providers/44506/).

(66) Smithy, Kate. Are podcasts the next big classroom alternatives. - 2014[Cited 15/8/ 2014]. - Available at: (http:// doteduguru.com/id9447-arepodcasts-the-next-bigclassroom-alternatives.htm)

(67) The Open Education Consor- 
study of student satisfaction in a blended e-learning system environment. - Computers \& Education . - 55 (2010). pp155-164.

(75) Zulli ,Floyd,. CBS Sunrise Semester. [Video on YouTube], 2013 . - [Cited 21/ 7/ 2014] Available at : (https:// www.youtube.com/watch? v=5_Q-Mw6qH9k).
21/ 9/ 2014] Available at: (http://opencontent.org/blog/ archives/2436).

(73) Winston, Hannah. Helping Professors Use Technology Is Top Concern in Computing Survey. -Retrieved 21

Sep.,2014. - Available at:

(http://chronicle.com/article/ Helping-Faculty-MembersUse/142377/)

(74) Wu J, Tennyson RD, Hsia T. A

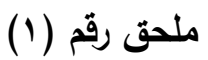

معايير موك، بالتطبيق على المنصات الدولية

\begin{tabular}{|c|c|c|c|c|c|c|c|c|c|}
\hline \multicolumn{3}{|c|}{ كورسيرا } & \multicolumn{3}{|c|}{ إيدكس } & \multicolumn{3}{|c|}{ يوديستي } & \multirow[b]{2}{*}{ العبارات } \\
\hline غوافيز & محايد & موافق & موافيّ & محايد & موافق & غير موافق & محايد & موافق & \\
\hline$r$ & $r$ & 94 & $r$ & $r$ & $9 \varepsilon$ & 0 & $r$ & 94 & 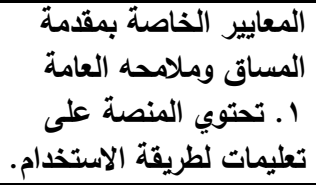 \\
\hline 1 & $r$ & $9 V$ & $r$ & $r$ & 90 & $r$ & $r$ & 9 १ & أهدافـ المساقل. التعرف على \\
\hline$r$ & $r$ & $9 \leq$ & $\varepsilon$ & $r$ & 9 द & - & $\mathrm{v}$ & 94 & 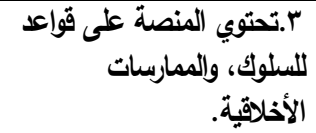 \\
\hline$r$ & 1 & 97 & 0 & $r$ & 94 & $r$ & r & 90 & بالوضوح ت بتسم السياسات \\
\hline 1 & $r$ & $9 V$ & 0 & 0 & 9. & 1 & $r$ & 94 & هابقا قبل خوض الخبرات المطلوية. \\
\hline 7 & $r$ & qr & $\varepsilon$ & $r$ & 9 \& & 0 & r & 94 & لآلمهارض التقتية الألدتىقعة \\
\hline- & $r$ & 91 & - & $\wedge$ & qr & - & $r$ & $9 \mathrm{~V}$ & مناسباً بالمدرب أو أو رابطاً \\
\hline- & $r$ & 9V & $r$ & 1 & QY & 1 & 1 & 94 & 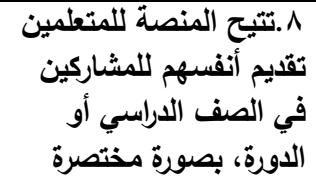 \\
\hline
\end{tabular}




\begin{tabular}{|c|c|c|c|c|c|c|c|c|c|}
\hline$r$ & $r$ & 97 & $r$ & $\varepsilon$ & $9 r$ & $r$ & $r$ & $9 \leq$ & متوسط المعيار \\
\hline 10 & $\Lambda$ & $v V$ & $1 \varepsilon$ & Ir & $V \leq$ & $\mathrm{V}$ & 18 & $\sqrt{17}$ & أ أهداف التعلم و الكفاءات التعلم قابلة \\
\hline$\varepsilon$ & $\Lambda$ & $\wedge \wedge$ & 7 & $r$ & $9 r$ & $r$ & $\Lambda$ & 9. & 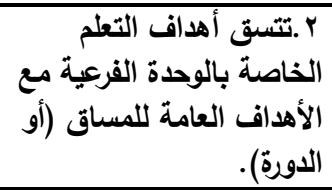 \\
\hline$r$ & 9 & $\wedge \wedge$ & $r$ & $\Lambda$ & 9. & $r$ & $r$ & 97 & بالمنتشقية. أهداف التعلم \\
\hline$r$ & YI & $\sqrt{ } 7$ & 0 & rr & $V r$ & $r$ & $r$ & $V V$ & 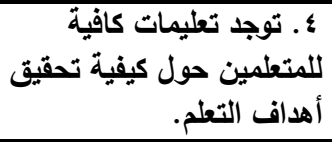 \\
\hline$r$ & $r r$ & Vo & $r$ & rr & V & 1 & YI & $\vee \wedge$ & 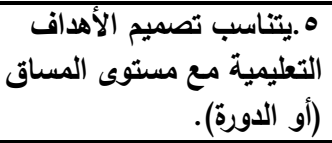 \\
\hline 0 & $1 \leq$ & $\wedge 1$ & 7 & Ir & $\wedge 1$ & $\varepsilon$ & $1 \leq$ & $\Lambda r$ & متوسط المعيار م \\
\hline$r$ & $\mathrm{~V}$ & 9. & $r$ & 7 & $9 r$ & 1. & 7 & $\Lambda \leq$ & 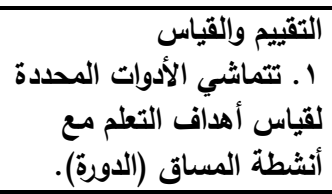 \\
\hline- & $r$ & $9 \wedge$ & -- & $r$ & 91 & 1. & $r$ & $9 V$ & الموتفيه لتقييم أعماليز محددة \\
\hline 7 & $r$ & 91 & $r$ & 0 & $q r$ & 1 & 1. & 19 & 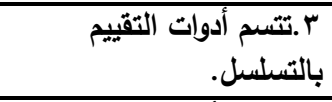 \\
\hline$r$ & $r$ & $9 \leq$ & r & $r$ & 97 & $r$ & $r$ & 90 & بالتنوع. تتسم أدوات التقييم \\
\hline 0 & 1 & $9 \leq$ & $r$ & $r$ & 94 & 0 & $r$ & $9 r$ & متعددة لقياس المتعلمين فرصمه في التعليمية \\
\hline$r$ & r.o & 94.0 & 1.0 & $\{.0$ & $9 \leq$ & r.o & 0 & $\begin{array}{l}91.0 \\
\%\end{array}$ & متوسط المعيار \\
\hline$r$ & v & 9. & $r$ & 7 & $q r$ & 1. & 7 & $\Lambda \leq$ & 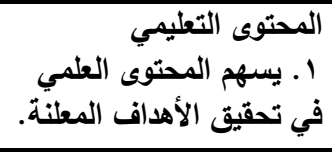 \\
\hline & $r$ & $9 \wedge$ & - & $r$ & 91 & 1. & $r$ & $9 V$ & 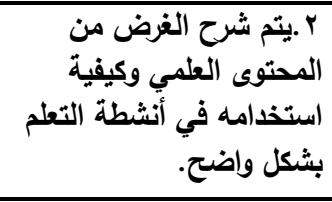 \\
\hline 7 & $r$ & 91 & $r$ & 0 & $q r$ & 1 & 1. & 19 & 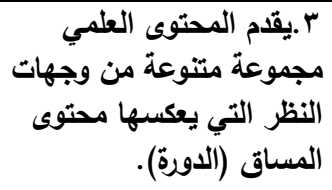 \\
\hline
\end{tabular}


العدد الرابع والخمسـون - 7 •

\begin{tabular}{|c|c|c|c|c|c|c|c|c|c|}
\hline$r$ & $r$ & $9 \leq$ & $r$ & $r$ & 97 & $r$ & r & 90 & متوسط المعيار \\
\hline 0 & $r$ & QY & $v$ & $r$ & 91 & $r$ & $r$ & 90 & 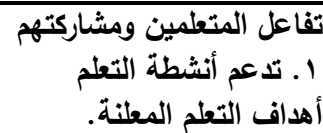 \\
\hline $\mathrm{v}$ & $r$ & 91 & 0 & $\mathrm{v}$ & $\Lambda \Lambda$ & 7 & 0 & 19 & 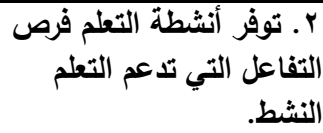 \\
\hline$r$ & $r$ & 90 & 0 & $r$ & $9 \pi$ & $\bar{r}$ & $r$ & 99 & 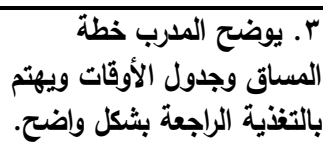 \\
\hline 1. & $\mathrm{v}$ & $\Delta \Gamma$ & $\mathrm{v}$ & $\mathrm{v}$ & 14 & 11 & $r$ & AV & 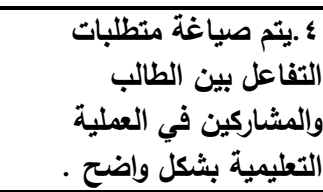 \\
\hline 0.0 & $\xi .0$ & 9. & 7 & \$. & 19.0 & 0.0 & Y.o & $9 Y$ & متوسط المعيار \\
\hline$\varepsilon$ & $r$ & $9 \xi$ & 0 & $r$ & $9 r$ & 0 & $\varepsilon$ & 91 & 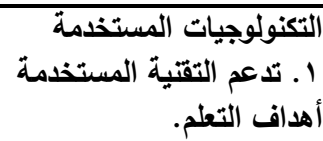 \\
\hline $\mathrm{v}$ & $r$ & 9. & 11 & $r$ & $\Lambda V$ & 0 & $r$ & $9 \pi$ & الثنطين. تلعمين ليصبحوا متعلمينة المستخدة \\
\hline$\Lambda$ & 1 & $9 \pi$ & $\Lambda$ & 1 & 91 & $\Lambda$ & $r$ & 95 & 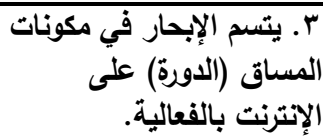 \\
\hline$r$ & $r$ & 90 & 0 & $r$ & 94 & 0 & $r$ & 95 & الــ الإنترنت (الإبحرة) على في مكونات \\
\hline$r$ & $r$ & 99 & $r$ & $r$ & 94 & $r$ & $r$ & 90 & 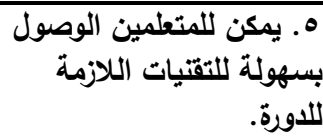 \\
\hline$\varepsilon$ & $r$ & $9 \leqslant$ & 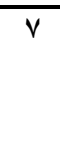 & $r$ & 91 & 0 & $r$ & 94 & الاليسنول استخدام المساق (الدورة). \\
\hline \&.0 & $r$ & 94.0 & v & $r$ & 91 & \&.0 & Y.o & 94 & متوسط المعيار \\
\hline 7 & $r$ & 94 & 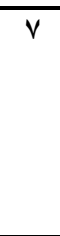 & $r$ & 91 & $r$ & $r$ & $9 \leq$ & 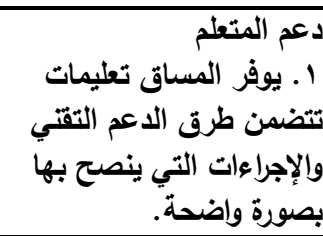 \\
\hline 7 & $T$ & $9 \pi$ & $r$ & $r$ & $9 \leqslant$ & $\xi$ & $r$ & 94 & بالدورة بالوضو التعليمات المتعلقة \\
\hline$r$ & $r$ & $9 \leqslant$ & $r$ & 0 & $9 r$ & $\bar{v}$ & $r$ & 91 & بالوباسات وخلمات التعليمات المتعلقة \\
\hline
\end{tabular}




\begin{tabular}{|c|c|c|c|c|c|c|c|c|c|}
\hline 0 & $r$ & 94 & 1. & 0 & 10 & 1. & r & $\Lambda \wedge$ & 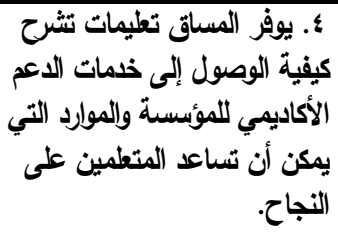 \\
\hline 0 & r & 94 & $\mathrm{v}$ & Y.o & $9 . .0$ & 7.0 & $r$ & 91.0 & متوسط المعيار \\
\hline r & $\varepsilon$ & $9 \leqslant$ & 0 & $\varepsilon$ & 91 & $r$ & 0 & 95 & 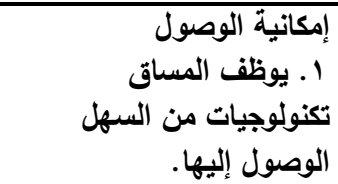 \\
\hline$r$ & 0 & $9 r$ & r & $\mathrm{v}$ & 91 & 1 & 7 & 94 & 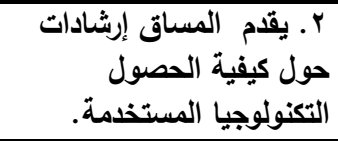 \\
\hline\{ & 1 & 90 & r & $\wedge$ & 9. & r & $v$ & 91 & 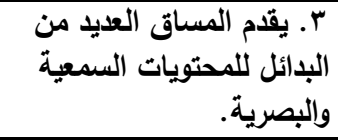 \\
\hline r & $r$ & $9 \leq$ & 0 & $\wedge$ & AV & 0 & $\varepsilon$ & 91 & القراعة ويسلل من الانحيم المساقات. \\
\hline
\end{tabular}

$$
\text { ملحق رقم ( ب مائمة المراجعة ) }
$$

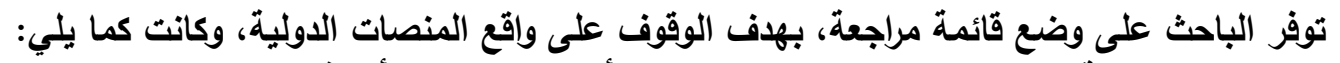

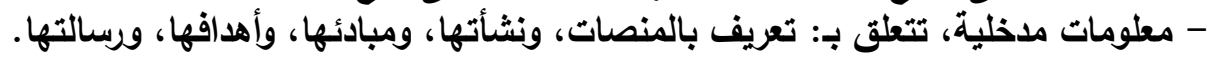

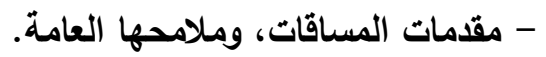

$$
\begin{aligned}
& \text { - أهداف التعلم - المئمات } \\
& \text {-التقييم والقياس. } \\
& \text { - المحتوى التعليمي. } \\
& \text { - تفاعل المتعلمين ومشاركتهم. } \\
& \text { - التكنولوجيات المستخدمة. }
\end{aligned}
$$

\begin{tabular}{|c|c|c|c|}
\hline الجامعة & الأستاذ الأ & عنوان المساق & ? \\
\hline \multicolumn{4}{|c|}{ أولاً: منصة كورسيرا } \\
\hline Stanford & Keith Devlin_ & $\begin{array}{c}\text { introduction to Mathematical } \\
\text { Thinking }\end{array}$ & .1 \\
\hline Duke & Dorian A. Canelas & $\begin{array}{l}\text { Introduction to Chemistry: } \\
\text { Reactions and } \\
\text { Ratios }\end{array}$ &.$r$ \\
\hline
\end{tabular}

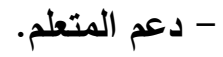

$$
\begin{aligned}
& \text { - إمكانية الوصول. }
\end{aligned}
$$

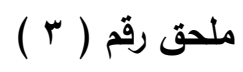

قائمة بأسماء المساقات التي تم الولوج إليها 
العدد الرابع والخمسـون - 7 •

\begin{tabular}{|c|c|c|c|}
\hline New Mexico_ & Doug E Thomas, Ph.D. & $\begin{array}{l}\text { International Business I- } \\
\text { Negocios } \\
\text { Internacionales } 1\end{array}$ &.$r$ \\
\hline California, San Diego & $\begin{array}{r}\text { Dr. \&Dr. Barbara Oakley } \\
\text { Terrence Sejnowski }\end{array}$ & $\begin{array}{r}\text { Learning How to Learn: } \\
\text { Powerful mental tools to } \\
\text { help you master tough } \\
\text { subjects }\end{array}$ &.$\varepsilon$ \\
\hline Arizona & Chris Impey & $\begin{array}{r}\text { Astronomy: Exploring Time } \\
\text { and Space }\end{array}$ & .0 \\
\hline Amsterdam & Rutger de Graaf & $\begin{array}{r}\text { Introduction to } \\
\text { Communication Science }\end{array}$ & .7 \\
\hline Pennsylvania & etal]]...Anita Allen & $\begin{array}{r}\text { An Introduction to American } \\
\text { Law }\end{array}$ &.$V$ \\
\hline Rice University & etal]]...Joe Warren & $\begin{array}{r}\text { An Introduction to } \\
\text { Interactive Programming in } \\
\text { Python (Part 1) }\end{array}$ &.$\wedge$ \\
\hline تيخون & حسام حايك & التقانة والمستشعرات النانوية & .9 \\
\hline San José State & Michael Stephens & Hyperlinked Library & .1 \\
\hline & & صةٌة إياكس & ثُانياً: \\
\hline $\begin{array}{l}\text { Margaret's Episcopal } \\
\text { School }\end{array}$ & JeneenGraham...etal & Introduction to Psychology & .1 \\
\hline National Circus School & lan Shrier...etal & The Body Matters &.$r$ \\
\hline $\begin{array}{r}\text { Massachusetts Institute } \\
\text { of Technology }\end{array}$ & $\begin{array}{l}\text { Eugene Fitzgerald } \\
\text { Richard Taylor }\end{array}$ & $\begin{array}{l}\text { Symmetry, Structure and } \\
\text { Tensor Properties of Materi- } \\
\text { als }\end{array}$ &.$r$ \\
\hline $\begin{array}{l}\text { Massachusetts Institute } \\
\text { of Technology }\end{array}$ & $\begin{array}{l}\text { Eric Grimson } \\
\text { John Guttag } \\
\text { Ana Bell }\end{array}$ & $\begin{array}{l}\text { Introduction to Computa- } \\
\text { tional Thinking } \\
\text { and Data Science }\end{array}$ &.$\varepsilon$ \\
\hline Harvard & $\begin{array}{l}\text { David J. Malan } \\
\text { Rob Bowden } \\
\text { Zamyla Chan } \\
\text { Allison Buchholtz-Au }\end{array}$ & $\begin{array}{l}\text { Introduction to Computer } \\
\text { Science }\end{array}$ & .0 \\
\hline California, Los Angeles. & Maggie Sokolik & $\begin{array}{l}\text { English Grammar and Essay } \\
\text { Writing }\end{array}$ & .7 \\
\hline Purdue & Bart Collins & Communicating Strategically &.$v$ \\
\hline California, Berkeley & $\begin{array}{l}\text { Dacher Keltner } \\
\text { Emiliana Simon-Thomas }\end{array}$ & The Science of Happiness &.$\wedge$ \\
\hline Chicago & Sara Ray Stoelinga & $\begin{array}{l}\text { Critical Issues in Urban } \\
\text { Education }\end{array}$ & .9 \\
\hline Harvard & Rafael Irizarry & $\begin{array}{l}\text { Advanced Statistics for the } \\
\text { Life Sciences }\end{array}$ & .1 \\
\hline \multicolumn{4}{|c|}{ ثُانيا: منصة يوداسيتي } \\
\hline Virginia & $\begin{array}{l}\text { Sebastian Thrun } \\
\text { and David Evans }\end{array}$ & $\begin{array}{l}\text { Introduction to Computer } \\
\text { Science }\end{array}$ & .1 \\
\hline
\end{tabular}

$1 \wedge 0$ 


\begin{tabular}{|c|c|c|c|}
\hline $\begin{array}{l}\text { BrownUniversity } \\
\text { Georgia Institute of } \\
\text { Technology }\end{array}$ & $\begin{array}{l}\text { Charles Isbell and } \\
\text { Michael Littman }\end{array}$ & $\begin{array}{l}\text { Machine Learning 2- } \\
\text { Unsupervised } \\
\text { Learning }\end{array}$ &.$Y$ \\
\hline MongoDB & Shannon Bradshaw & $\begin{array}{l}\text { Intro to Inferential Statistics: } \\
\text { Making } \\
\text { Predictions from Data }\end{array}$ &.$\Gamma$ \\
\hline Stanford & Peter Norvig & Design of Computer Programs &.$\varepsilon$ \\
\hline Stanford & Sebastian Thrun & Introduction to Statistics & .0 \\
\hline San Jose State & $\begin{array}{l}\text { Julie Sliva Spitzer and } \\
\text { Miriam Swords Kalk }\end{array}$ & College Algebra & .7 \\
\hline California, Davis & $\begin{array}{l}\text { John Owens and } \\
\text { David Luebke }\end{array}$ & Intro to Parallel Programming &.$v$ \\
\hline $\begin{array}{l}\text { Georgia Institute of } \\
\text { Technology }\end{array}$ & Alex Orso & $\begin{array}{l}\text { Software Development Life Cy- } \\
\text { cles }\end{array}$ &.$\wedge$ \\
\hline $\begin{array}{l}\text { Georgialnstituteof } \\
\text { Technology }\end{array}$ & Nick Feamster & $\begin{array}{l}\text { Computer Networking: Security } \\
\text { and } \\
\text { Software Defined Networking }\end{array}$ & .9 \\
\hline San Josie State & $\begin{array}{l}\text { Cay Horstmann } \\
\text { Cheng-Han Lee } \\
\text { Sara Tansey }\end{array}$ & Intro to Java Programming & 1. \\
\hline
\end{tabular}

\section{ملحق رقم ( ع ) ملتمين}

قائمة المحكمين، الأين تم تلقي الرد منهم

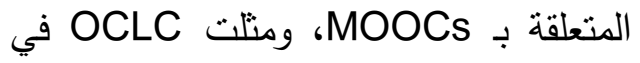
مؤتمر المكتبات وموك والتعليم على الخط Libraries, MOOCs and المباشر التركر OCLC الذي عقد بمقر online learning

$$
\text { في مارس ع (.r. }
$$

Sمحرر رئيس بـ Schwartz, Meredithالها عدد من الدراسات

$$
\text { حول موك }
$$

الأستاذ المساعد Michael Stephens -

بقسم المكتبات والمعلومات، بجامعة ولاية

سان جوس San José State

University (SJSU)

Hyperlinked Library الوحيد في مجال المكتبات حتى الآن. Merrilee Proffitt بمركز OCLC، لها عدد من الدراسات 